



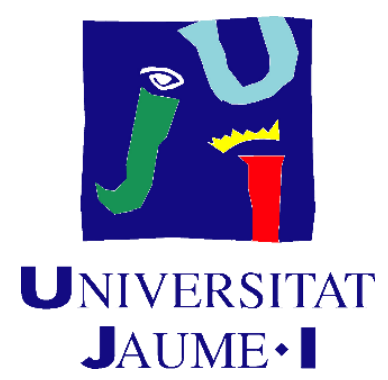

Programa de Doctorat en Economia y Empresa/ Programa de Doctorado en Economía y Empresa

Escola de Doctorat de la Universitat Jaume I / Escuela de Doctorado de la Universitat Jaume I

Sustainability In Microfinance Institutions/ Sostenibilidad En Las Instituciones Microfinancieras

Memòria presentada per Icíar García Pérez per a optar al grau de doctora per la Universitat Jaume I

Memoria presentada por Icíar García Pérez para optar al grado de doctora por la Universitat Jaume I

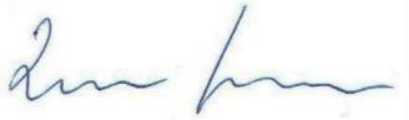

Icíar García Pérez

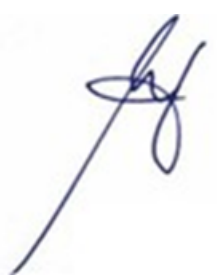

María Jesús Muñoz Torres

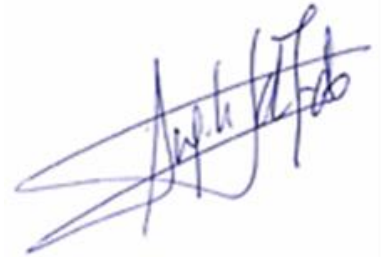

María Ángeles Fernández Izquierdo

Castelló de la Plana, novembre 2018

Castellón de la Plana, noviembre 2018 



\section{Finançament rebut}

- Contracte predoctoral FPI UJI

- Máster Interuniversitario en Sostenibilidad y RSC (UNED-UJI)

- Grup universitari d'investigació: Sostenibilidad de las Organizaciones y Gestión de la Responsabilidad Social-MF.

\section{Financiación recibida}

- Contrato predoctoral FPI UJI

- Máster Interuniversitario en Sostenibilidad y RSC (UNED-UJI)

- Grupo universitario de investigación: Sostenibilidad de las Organizaciones y Gestión de la Responsabilidad Social-MF. 

A Juanjo, por darme raíces

A Andrés y Alejandra, por darme la vida 



\section{Agradecimientos}

El proceso de escribir esta tesis ha sido un camino de aprendizaje a diferentes niveles. En ocasiones ha sido un trabajo duro que ha requerido esfuerzo, pero que he disfrutado enormemente sin duda, gracias todas esas personas que me han acompañado y que han contribuido a materializar lo que inicialmente eran ideas en abstracto.

Agradecer a mis directoras de tesis, la Dra. María Jesús Muñoz Torres y la Dra. Ángeles Fernández Izquierdo, por su decisión de dirigir esta tesis y permitirme participar en su equipo. Me resulta imposible separar cuánto de su apoyo ha sido profesional y cuánto personal. Es un privilegio aprender de ellas, de lo académico y de lo vital. Su acompañamiento durante todo este recorrido ha sido clave para madurar como investigadora y como persona.

A las personas con las que trabajo cada día, un equipo de investigación en el que cooperación, conciliación, colaboración y transparencia son valores que se manifiestan de manera natural. Una tribu formada mayoritariamente por mujeres maravillosas de las que aprendo y me nutro cada día. Agradezco enormemente su generosidad, dedicación, paciencia y cariño con el que atienden mis inquietudes y aspiraciones profesionales y personales. Gracias por toda la felicidad que aportáis a mi vida.

Al Dr. Rodrigo Lozano, gracias. Todas las contribuciones que has hecho me están ayudando a aprehender la naturaleza propia de la escritura de artículos científicos.

A todos los expertos que durante este periodo han participado activamente, en particular a la Dra. Marta De la Cuesta González y a todos aquellos revisores de las revistas que con sus comentarios han enriquecido el contenido de cada uno de los artículos.

A mi abuela María y a mi madre, mujeres autónomas y con carácter, gracias por todo el camino que habéis recorrido antes que yo. En mi ADN llevo vuestra voluntad de trabajo y esfuerzo. 


\section{Agradecimientos}

A Alma, gracias por acompañarme, aunque fuese por un breve espacio de tiempo.

A Andrés y Alejandra, en ocasiones esta tesis ha requerido una dedicación que me ha restado tiempo para atenderos de una manera plena. Gracias por aceptarlo y entenderlo.

A Juanjo, a quien más esfuerzo ha supuesto esta tesis, gracias por estar ahí de manera incondicional, ocuparte de los asuntos a los que yo no alcanzaba y por hacerlo además, siempre con una actitud positiva y sin dejar de animarme para que siguiese adelante. 


\section{Índice de contenidos}

Introducción

Capítulo I. García-Pérez, I., Muñoz-Torres, M. J., \& Fernández-Izquierdo, M. Á. (2017). Microfinance literature: A sustainability level perspective survey. Journal of Cleaner

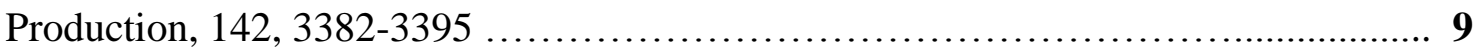

Capítulo II. García-Pérez, I., \& Muñoz-Torres, M. (2015). Evaluación integral de las entidades microfinancieras desde la perspectiva de sostenibilidad. Harvard Deusto Business Research, 4(1), 17-33 61

Capítulo III. García-Pérez, I., Muñoz-Torres, M. J., \& Fernández-Izquierdo, M. Á. (2018). Microfinance institutions fostering sustainable development. Sustainable Development 91

Conclusiones 129 

El término sostenibilidad interrelaciona el desempeño económico con las necesidades y el bienestar, tanto de la sociedad como de los individuos (Brundtland, 1987). Esta perspectiva de prosperidad social y económica colisiona con la amenaza de consecuencias socioecológicas sin precedentes como resultado de la actividad económica que transgrede los límites planetarios (Dyllick y Hockerts, 2002; Rockström et al., 2009; Steffen et al., 2015).

En este sentido, el concepto Triple Bottom Line (TBL) (Elkington, 1997) proporcionó, en un principio, una contribución fundamental a la conexión de las tres dimensiones de la sostenibilidad -financiera, medioambiental y social-fundadas en un equilibrio entre los objetivos de equidad social, respeto medioambiental y progreso económico.

Como la evolución lógica del marco TBL original, el concepto de sostenibilidad incorpora también la dimensión de gobernanza. En este sentido, al evaluar la sostenibilidad de una organización, es crucial combinar de manera óptima los mecanismos de gobernanza (Galema et al., 2012; Hartarska, 2005; Mersland y Strøm, 2009) y lograr transparencia, participación y responsabilidad óptimas en sus sistemas de gobierno (Bakker et al., 2014; Kolk, 2008).

Con esta inclusión, la sostenibilidad integra cuatro dimensiones interdependientes: financiera, ambiental, social y de gobernanza (FASG), considerando un equilibrio adecuado entre ellas (Gladwin et al., 1995; Starik y Kanashiro, 2013) a corto y largo plazo (Elsen, 1998; Lozano y Huisingh, 2011).

El sistema financiero afecta al desarrollo sostenible de manera directa e indirecta (Beck et al., 2010; Hu y Scholtens, 2014, Busch et al., 2016). Entre la gran diversidad de agentes que proveen servicios de intermediación en el sector financiero, el sector microfinanciero está considerado una pieza fundamental para el fortalecimiento y la expansión del sistema financiero formal (Vanroose y D’Espallier, 2013; Lopatta et al., 2017;).

El término microfinanzas se refiere a la provisión de productos y servicios financieros a clientes de bajos ingresos, (van Rooyen et al., 2012). Este sector se encuentra 


\section{Introducción}

en continuo crecimiento y se ha convertido en el mercado bancario más grande del mundo en términos de clientes atendidos (Mersland, 2013) y está considerado como uno de los más dinámicos en el mundo de la cooperación, la promoción de la inclusión financiera (Ledgerwood et al., 2013) y el alivio de la pobreza (Yunus 1999, Robinson 2001). Asimismo, se considera que los programas de microfinanzas tienen gran potencial para generar un desarrollo equitativo y sostenible (Rahman, 1999, Stevens y Morris, 2001), e incrementar el bienestar de millones de personas (Coleman, 2006; Quayes, 2012; Azad et al., 2016).

Las instituciones microfinancieras (IMF) como actores clave en el sector de las microfinanzas, requieren un marco de gestión organizacional que facilite el desarrollo sostenible. Esto se refleja en la literatura académica en un interés creciente por incluir en los trabajos publicados cada una de las áreas de los criterios FASG. Sin embargo, estudios previos citan carencias en la investigación bajo un enfoque integrador de sostenibilidad (Haughton, 1999; Moran et al, 2008; Pérez, 2011; Saint-Supéry Ceano-Vivas et al., 2014).

Por ello, el tema fundamental que hemos elegido para esta tesis es el análisis de la sostenibilidad en las organizaciones microfinancieras bajo la perspectiva FASG que interrelacione las cuatro dimensiones de manera equilibrada e integrada. Desde el inicio, el planteamiento fue una tesis de compendio que recogiese tres artículos bajo esta misma unidad temática.

El primero de ellos lleva por título Microfinance literature: A sustainability level perspective survey y ha sido publicado en la revista Journal of Cleaner Production en 2017. El objetivo de este artículo es analizar la contribución de la investigación académica sectorial de microfinanzas a la sostenibilidad. Para ello, se ha contextualizado la producción científica y estudiado su terminología específica mediante una revisión bibliográfica sistemática. Esta revisión se ha llevado a cabo considerando las directrices de los criterios FASG y bajo el marco de referencia de la guía Global Reporting Initiative.

El trabajo fue presentado en un estado preliminar, en el III Symposium on Ethics and Social Responsibility Research, celebrado en la Universidad de Extremadura en mayo 
de 2015, mediante una ponencia denominada Microfinance analysis from the sustainability perspective.

En mayo 2017, fue defendido, en su estado más desarrollado, en el XXV Congreso EBEN Spain 2017, con el título Reporting as a driver of more sustainable organisations in the microfinance sector.

El método de análisis llevado a cabo, se expuso en un seminario organizado por la Universidad de Zaragoza en abril de 2018, con el nombre Systematic Literature review based on keyword analysis. Case of microfinance literature from a sustainability level perspective.

Posteriormente, en el segundo capítulo, presentamos una evaluación integral e inclusiva de las entidades microfinancieras que permita obtener una mejor comprensión de la situación actual de estas instituciones. Este artículo fue publicado con el nombre Evaluación integral de las entidades microfinancieras desde la perspectiva de sostenibilidad, en la revista Harvard Deusto Business Research en 2015.

Los resultados de este trabajo permiten reflejar el comportamiento actual de las IMFs y detectar aspectos que necesitan ser revisados en el sector para garantizar la sostenibilidad de estas instituciones y permitir una adecuada gestión de los programas de financiación en todas sus dimensiones, como son: el sobreendeudamiento, el impacto ambiental derivado de las actividades financiadas o los objetivos de reducción de pobreza y empoderamiento de las mujeres, entre otros.

Una versión previa de esta investigación se expuso durante el $I V$ Taller Doctorandos en Ética Empresarial, RSE y Sostenibilidad, organizada por la Cátedra de Ética Económica y Empresarial de la Universidad Pontificia Comillas en julio de 2014.

En la tercera publicación abordamos los diferentes perfiles de sostenibilidad de las IMFs. A través de un proceso de agrupamiento, esta investigación establece la relación entre los diversos indicadores de sostenibilidad proporcionados por MixMarket, determina los diferentes perfiles de sostenibilidad de las IMF, así como permite detectar 


\section{Introducción}

aquellos aspectos susceptibles de mejora en la gestión equilibrada de las distintas dimensiones FASG.

Un análisis preliminar de este capítulo se expuso en el Sustainable Market Actors for Responsible Trade (SMART) EU Horizon 2020 project, celebrado en junio 2017 en la Universidad Pontificia de Comillas de Madrid.

En abril de 2018, los resultados más avanzados de este trabajo fueron presentados con el título Microfinance Institutions fostering Sustainable Development en la primera sesión del Workshop de doctorandos en Economía y Empresa de la Universitat Jaume I de Castellón.

El artículo en su versión definitiva fue publicado en la revista Sustainable Development bajo el título Microfinance institutions fostering sustainable development en enero de 2018.

Así pues, el objetivo conjunto de esta tesis es contribuir a la literatura académica acerca de las organizaciones microfinancieras basada en métodos que aportan validez, fiabilidad y confiabilidad para la evaluación del sector desde una perspectiva de sostenibilidad.

\section{Referencias}

Azad, M. A. K., Masum, A. K. M., Munisamy, S., \& Sharmin, D. F. (2016). Efficiency analysis of major microfinance institutions in Bangladesh: A Malmquist index approach. Quality and Quantity, 50(4), 1525-1537. https://doi.org/10.1007/s11135-0150219-8.

Bakker, A., Schaveling, J., \& Nijhof, A. (2014). Governance and microfinance institutions. Corporate Governance: the International Journal of Business in Society, 14(5), 637-652. https://doi.org/10.1108/CG-03-2014-0032.

Beck, T., Demirgüç-Kunt, A., \& Levine, R. (2010). Financial institutions and markets across countries and over time: The updated financial development and structure 


\section{Introducción}

database. World Bank Economic Review, 24(1), 77-92. https://doi.org/10.1093/wber/lhp016.

Brundtland, G. H. (1987). Our Common Future: Report of the 1987 World Commission on Environment and Development. Oslo, Norway: United Nations.

Busch, T., Bauer, R., \& Orlitzky, M. (2016). Sustainable development and financial markets: Old paths and new avenues. Business and Society, 55(3), 303-329.

Coleman, B. E. (2006). Microfinance in Northeast Thailand: Who benefits and how much? World Development, 34(9), 1612-1638. https://doi.org/10.1016/j.worlddev.2006.01.006.

Dyllick, T., \& Hockerts, K. (2002). Beyond the business case for corporate sustainability. Business Strategy and the Environment, 11(2), 130-141. https://doi.org/10.1002/bse.323.

Elkington, J. (1997). Cannibals With Forks: The Triple Bottom Line of 21 st Century Business (p. 402). Oxford: Capstone. ISBN 1-900961-27-X.

Elsen, A. (1998). Sustainable development research at the University of Amsterdam. Amsterdam: United Nations Environment Programme.

Galema, R., Lensink, R., \& Mersland, R. (2012). Do powerful CEOs determine microfinance performance? Journal of Management Studies, 49(4), 718-742. https://doi.org/10.1111/j.1467-6486.2012.01046.x.

Gladwin, T. N., Kennelly, J. J., \& Krause, T.-S. (1995). Shifting paradigms for sustainable development: Implications for management theory and research. Academy of Management Review, 20(4), 874-907.

Hartarska, V. (2005). Governance and performance of microfinance institutions in central and Eastern Europe and the newly independent states. World Development, 33(10), 1627-1643. https://doi.org/10.1016/j.worlddev.2005.06.001.

Haughton, G. (1999). Environmental justice and the sustainable cit. Journal of Planning Education and Research, 8(3), 233e243.

Hu, V. I., \& Scholtens, B. (2014). Corporate social responsibility policies of commercial banks in developing countries. Sustainable Development, 22(4), 276-288. https://doi.org/10.1002/sd.1551. 


\section{Introducción}

Kolk, A. (2008). Sustainability, accountability and corporate governance: Exploring multinationals' reporting practices. Business Strategy and the Environment, 17(1), 1-15. https://doi.org/10.1002/bse.511.

Ledgerwood, J., Earne, J., \& Nelson, C. (Eds.) (2013). The new microfinance handbook: A financial market system perspective. Washington DC: World Bank Publications.

Lopatta, K., Tchikov, M., Jaeschke, R., \& Lodhia, S. (2017). Sustainable development and microfinance: The effect of outreach and profitability on microfinance institutions' development mission. Sustainable Development, 25(5), 386-399. https://doi.org/10.1002/sd.1663.

Lozano, R., \& Huisingh, D. (2011). Inter-linking issues and dimensions in sustainability reporting. Journal of Cleaner Production, 19(2-3), 99-107. https://doi.org/10.1016/j.jclepro.2010.01.004.

Mersland, R., \& Strøm, R. Ø. (2009). Performance and governance in microfinance institutions. Journal of Banking \& Finance, 33(4), 662-669. https://doi.org/10.1016/j.jbankfin.2008.11.009.

Mersland, R. (2013). Market opportunities for microfinance institutions. Enterprise Development and Microfinance, 24(4), 282-294. https://doi.org/10.3362/17551986.2013.027.

Moran, D. D., Wackernagel, M., Kitzes, J. A., Goldfinger, S. H., \& Boutaud, A. (2008). Measuring sustainable development - Nation by nation. Ecological Economics, 64(3), 470-474. https://doi.org/10.1016/j.ecolecon.2007.08.017.

Perez, J. A. (2011). Conceptualizing a matrix to address sustainability and sustainable development in microfinance. Interdisciplinary Studies Journal, 1(2), 47.

Quayes, S. (2012). Depth of outreach and financial sustainability of microfinance institutions. Applied $\quad$ Economics, 34(26), 3421-3433. https://doi.org/10.1080/00036846.2011.577016.

Rahman, A. (1999). Micro-credit initiatives for equitable and sustainable development: Who pays? World Development, 27(1), 67-82. https://doi.org/10.1016/S0305-750X(98)00105-3. 


\section{Introducción}

Robinson, M. (2001). The microfinance revolution. Washington DC: The World Bank and Open Society Institution.

Rockström, J., Steffen, W., Noone, K., Persson, A., Chapin, F. S., Lambin, E. F., Foley, J. A. (2009). A safe operating space for humanity. Nature, 461(7263), 472-475. https://doi.org/10.1038/461472a.

Saint-Supéry Ceano-Vivas, M., Muñoz-Torres, M., \& Rivera Lirio, J. M. (2014). Revisiting the Relationship between Sustainable Development and Social Cohesion. https://doi.org/10.2139/ssrn.2521322.

Starik, M., \& Kanashiro, P. (2013). Toward a theory of sustainability management: Uncovering and integrating the nearly obvious. Organization and Environment, $\mathrm{XX}(\mathrm{X})$, $1 \mathrm{e} 24$.

Steffen, W., Richardson, K., Rockström, J., Cornell, S. E., Fetzer, I., \& Bennett, E. M. (2015). Sustainability. Planetary boundaries: Guiding human development on a changing planet. Science, 347(6223), 1259855. https://doi.org/10.1126/science.1259855.

Stevens, K., Morris, J., 2001. Struggling towards sustainability: considering grassroots development. Sustainable Development. 9 (3), 149e164.

van Rooyen, C., Stewart, R., \& de Wet, T. (2012). The impact of microfinance in sub-Saharan Africa: A systematic review of the evidence. World Development, 40(11), 2249-2262. https://doi.org/10.1016/j.worlddev.2012.03.012.

Vanroose, A., \& D’Espallier, B. (2013). Do microfinance institutions accomplish their mission? Evidence from the relationship between traditional financial sector development and microfinance institutions. Applied Economics, 45(15), 1965-1982.

Yunus, M. (1999). Banker to the poor (1st ed.). Public Affairs. 

A continuación se presenta la versión postprint del artículo con referencia:

García-Pérez, I., Muñoz-Torres, M. J., \& Fernández-Izquierdo, M. Á. (2017). Microfinance literature: A sustainability level perspective survey. Journal of Cleaner Production, 142, 3382-3395.

DOI: https://doi.org/10.1016/j.clepro.2016.10.128. 



\begin{abstract}
:
Since the early microcredit programs up to the present, microfinance has grown exponentially, as it has the academic interest on it as a research subject. Considering that this sector has impact in terms of sustainability, any research in the field requires an analysis with wide criteria, which should include the economic, environmental, social, and governance dimensions (EESG), as well as their interrelationships. The objectives of this survey are, to investigate the contributions of microfinance sectoral scholarly research to sustainability, through a systematic literature review using content analysis method, contextualizing the scientific production and studying its terminology according to the EESG criteria and under Global Reporting Initiative framework, and finally, to identify research gaps and to propose future research paths.
\end{abstract}

Key words: microfinance; sustainability; EESG; Global Reporting Initiative (GRI); systematic literature review; content analysis

\title{
1. Introduction and state of the art
}

Since the first modern microcredit programs, the microfinance sector has risen constantly; as much as has the mounting growth of the academic work that has microfinance as a subject.

The term microfinance refers to the provision of financial services to low-income clients through various services that usually evolve into microcredit, micro-insurance, micro-savings and money transfers (van Rooyen et al., 2012). Microfinance programmes have potential for equitable and sustainable development (Rahman, 1999; Stevens \& Morris, 2001).

In this paper, we focus on the microfinance industry, which is one of the most dynamic industries in the world of development cooperation (Ledgerwood, 1999) and poverty alleviation (Yunus, 1999; Robinson, 2001). These organizations follow a relatively uniform business practice across different institutional settings (Beisland et al. 2015). Microfinance is a high-growth industry poised to become the world's largest banking 
market in terms of customers served (Mersland et al., 2013). Unlike the traditional and commercial banking market, microfinance offers a broader geographical coverage, including developing and emerging markets.

Microfinance has attracted considerable public attention (Beisland et al, 2015) as an important contributor to the strengthening and expansion of the formal financial system (Ledgerwood, 1999), this system, affects sustainable development both directly and indirectly (Scholtens, 2008; Busch et al. 2016).

The definition of sustainability is complex and its interpretation is multidimensional. The term sustainability inter-relates economic performance with the needs and welfare, of both society and individuals (Brundtland Report, 1987), to protect and respect environmental limits (Brown et al., 1987; van Marrewijk, 2003) thus facilitating economic prosperity by internalising and reducing negative environmental and social externalities, creating a positive society within planetary boundaries (Boons \& LüdekeFreund, 2013). Thereby, the concept of sustainable development embraces three dimensions of welfare - economic, environmental and social — and strikes an appropriate balance among them (Gladwin et al., 1995; Starik \& Kanashiro, 2013).

Other definitions of sustainability incorporate the governance sphere as an extension of the triple bottom line accounting framework. In this sense, when assessing a firm's sustainability, it is important to find the best structures and mechanisms for achieving optimal transparency, participation and accountability in its governance systems (Kolk, 2008; Bakker et al., 2014).

With this final inclusion, measures of sustainability are considered from an economic, environmental, social and governance (EESG) perspective, giving equal attention to the various spheres.

It is a major challenge to render the sustainable management concept operational. The election of which framework or indicator to choose is not a simple matter, as the universe of rating systems, reporting guidelines, normative frameworks, management systems and their indicators is vast (Rahdari \& Rostamy, 2015). To achieve this goal, both academics 
and practitioners have proposed the use of various sustainability frameworks and indicators that provide specified levels of (either direct or indirect) information (Braat, 1991); simplify, quantify and summarize immense flows of data (Ciegis et al., 2009); and communicate complex information (Singh et al. 2012). As a framework, sustainability reporting has been widely used in sectoral analysis (Muñoz-Torres et al., 2008) and enables organizations to consider their impacts. Consistent with prior research, this paper regards the use of Global Reporting Initiative (GRI) guidelines as a summary variable of sustainability assessment as its guidelines are the unofficially accepted standard used by companies to prepare sustainability reports (Azapagic, 2004; Kaspereit \& Lopatta, 2016) among others.

In this work, we have opted for a systematic literature review (SLR) according to EESG criteria and under the GRI framework to illustrate how the microfinance sector scholarly research is tackling the sustainability concept.

There is growing interest in the inclusion of each of the EESG criteria in microfinance and this is reflected clearly in the literature, which includes studies on every dimension. Economic: where among other topics, there are addressed the different MFIs' structures and the two opposing approaches that consider that financial self-sufficiency of these organizations is necessary against those who believe that receiving subsidies facilitates social work by allowing charging lower interest rates (Morduch, 1999; Armendáriz de Aghion \& Morduch, 2005) and studies that evaluate the different group lending models and their influence in reducing default risk (Feigenberg et al. 2013).

Environmental: linking the management of environmental issues to the contribution of sustainable development (Hall et al., 2008), measuring the environmental performance of MFIs based on management performance indicators that have been adapted to the specificities of the microfinance sector (Allet, 2011), identifying the characteristics of the MFIs in terms of legal status, age, and profitability related to their better perform in environmental policy and environmental risk assessment (Allet \& Hudon, 2015) and pointing out the main environmental issues faced in the sector, which are: pollution, use of chemicals and pesticides, use of energy, destruction of forest (van Elteren, 2007). 
Social: research in this area is to provide information about the impact of microfinance on poverty, considering methodological options for the impact assessment (Hulme, 2000), examining the income asset holdings and diversity and various measures of vulnerability in order to determine the effectiveness of microfinance programs in comparison with other anti-poverty measures (Mosley, 2001) and searching for empirical evidence on the impact of microfinance with respect the combination poverty reduction and empowerment of poor women (Kabeer, 2005).

Governance: tracing the relationship between firm performance and corporate governance in MFIs and evaluating the effectiveness of several governance mechanisms as the board characteristics (Rock et al., 1998), competition and regulation and ownership type (Mersland \& Strøm, 2009; Hartarska \& Mersland, 2012).

Previous SLRs in this field have already been offered, as the one suggested by Brau and Woller (2004) and Granados et al. (2011) with the purpose of introducing microfinance to the academic finance community and determining the maturity of the field; the study by Moro Visconti (2012) which revolves around the concept of social responsibility; the work of Milana and Ashta (2012) where the evolution of the main facts and visions of microfinance over the time was gathered, or the studies by Khawari (2004), Hermes and Lensink (2007), or Sharma and Puri (2013) that regarded microfinance as a tool to alleviate poverty, and the impacts on income, health or education, among others (van Rooyen et al., 2012).

Nevertheless, to the best of the authors' knowledge, this is the first study that attempts to integrate a sustainability outlook, where every EESG criterion is included, based on a recognized sustainability framework with a business model as reference that includes both emerging and developing countries.

Thus, the paper offers a SLR of the scientific microfinance sectoral literature. The main goals of this study are as follows:

- To investigate the contributions of microfinance sectoral literature according to the EESG criteria and the GRI as framework. 
- To put in context the scientific production on microfinance, to study its terminology, and to provide a comprehensive analysis of this literature, considering the relation between and among the financial, environmental, social, and governance dimensions.

- To light up new pathways for future studies to achieve sustainability, promoting an integrative approach to research.

The results of this paper will allow us to identify and clarify the main terms and concepts associated with microfinance to facilitate an inclusive understanding among practitioners and academics. The outcomes of the analysis from the perspective of sustainability will reveal that when researching microfinance, there is no balance among the various spheres - economic, social, environmental and governance-.

The paper has the following structure: Section 2 describes the research scheme methodology, the material collection and the analysis process, Section 3 presents the contextualization of the microfinance sector scientific production, Section 4 shows the results of a comprehensive analysis of the articles' keywords, Section 5 discusses the contributions of microfinance sectoral literature to sustainability and Section 6 concludes the paper.

\section{Sample and methodology}

In this paper, from a methodological standpoint, to provide a SLR we have opted to use content analysis (Seuring \& Müller, 2008; Krippendroff, 2013) that considers both quantitative and qualitative methods to make inferences about the antecedents of communication (Holsti, 1969).

Starting with the material collection that will be explained in this section, we will continue with a description of the methodology process followed in the survey. We will present a descriptive analysis of the input data and after a clustering process, on the one 


\section{Microfinance Literature: A Sustainability Level Perspective}

Survey

hand, we will contextualize and characterize the microfinance sector by studying the most frequently appearing keywords in the articles applying the co-occurrence method, and on the other hand, we will assess the microfinance industry from a sustainability approach, coding the keywords according to the EESG criteria and the GRI framework categories. Figure 1 describes this survey's methodological process.

Figure 1. Research methodology process

Investigating the contribution of microfinance sectoral literature according to EESG criteria and GRI framework. An outline.

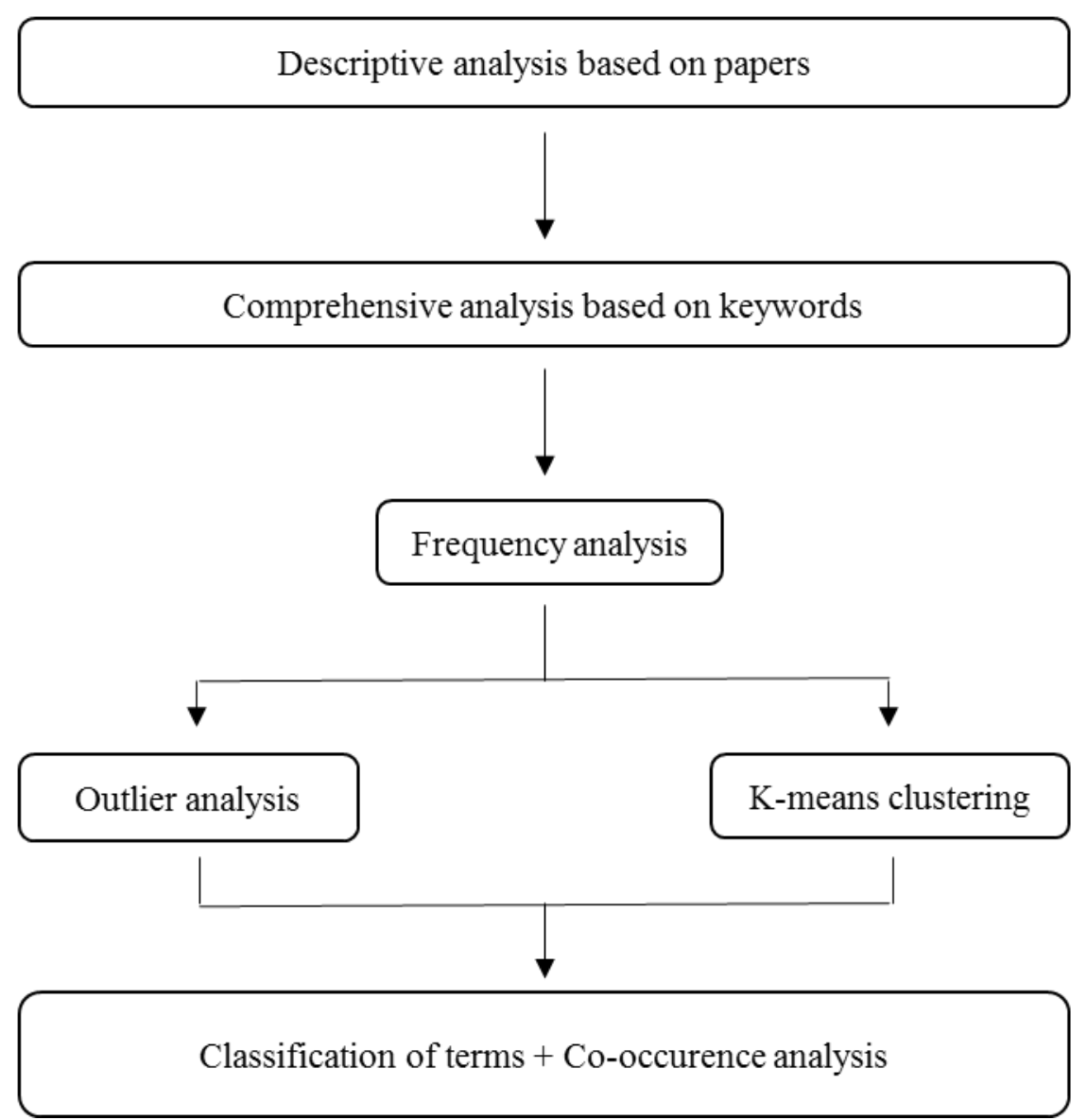

To achieve the categorization that allow us to determine the sustainability approach in the various papers, the organization and classification is based on the papers' keywords, 
however, the discussions presented in the following sections are based on the whole text of the paper.

\subsection{Material collection}

To provide a comprehensive analysis of the microfinance concept from an inclusive perspective, the review of the microfinance sectoral literature has focused on selecting a rigorous and reliable resource for the research. The Web of Science database was chosen for this purpose because it is a quality scientific reference and is one of the most comprehensive databases chosen by peer-reviewed journals in the social sciences (Falagas et al. 2008, Crossan \& Apaydin, 2010). It is multidisciplinary, suitable to provide uniform data quality, and built on defined and measurable criteria (Garfield 1975; Vos et al., 2013) that allow analysts to properly identify their research subjects (Okubo, 1997).

Given that this paper's purpose is to investigate the contribution of microfinance sector literature, we have explored the term microfinance in its maximum amplitude. We have opted for an inductive approach, with no previous expectations or fixed categories (Zhang \& Wildemuth, 2009).

Following other authors' method, the word microfinance has been entered into Thomson Reuters' Web of Science search engine, returning every article in which this term appears in the topic (Plümper \& Radaelii, 2004; Crossan \& Apaydin, 2010), this is, the word microfinance appears in the title, keywords or abstract and subsequently, there has been a thorough analysis of keywords added by the Web of Science database indexers (Cambrosio et al., 1993; Ding et al., 2001; Emrouznejad et al., 2008).

In 1976, Grameen Bank began to offer its first microfinance programmes to selected villages in India, a project that has become more active since 1983, when the bank became independent. Nevertheless, it was not until 1993 that the first microfinance-related article was registered in the Web of Science database. To contextualize the microfinance theme we base our results on a population of 996 articles found from 1993 to June 2016 in which 
Microfinance Literature: A Sustainability Level Perspective Survey

the word microfinance appears in the topic, which means that appears in the title, abstract, or keywords.

However, in order to have a smaller and more precise paper sample and because the keywords represent topics of significance that describe the content of a body of text, to appraise the studied concept we will examine the 475 articles that contained the term microfinance specifically as a keyword and not only in the title and/or abstract.

Therefore, we will frame the topic contextualizing the microfinance sector literature surveying its scientific production based on a larger sample and then we will carry out an analysis of the terminology and the relationship between concepts through a more accurate sample, based on articles that contain the word microfinance specifically as a keyword.

All of the keywords that accompany the keyword microfinance were coded to establish a relation between these expressions in terms of an EESG classification. As a result, 2,534 words were coded (1,105 excluding repetitions). At this point, we select the characteristic terminology and thereby we have considered from the total of registered keywords those whose frequency of appearance is equal to or above average, resulting in a total of 201 of different keywords. See Figure 2 for the schematic representation of the selection process of the analysis units. 
Figure 2. Diagram of the selection process of the analysis units

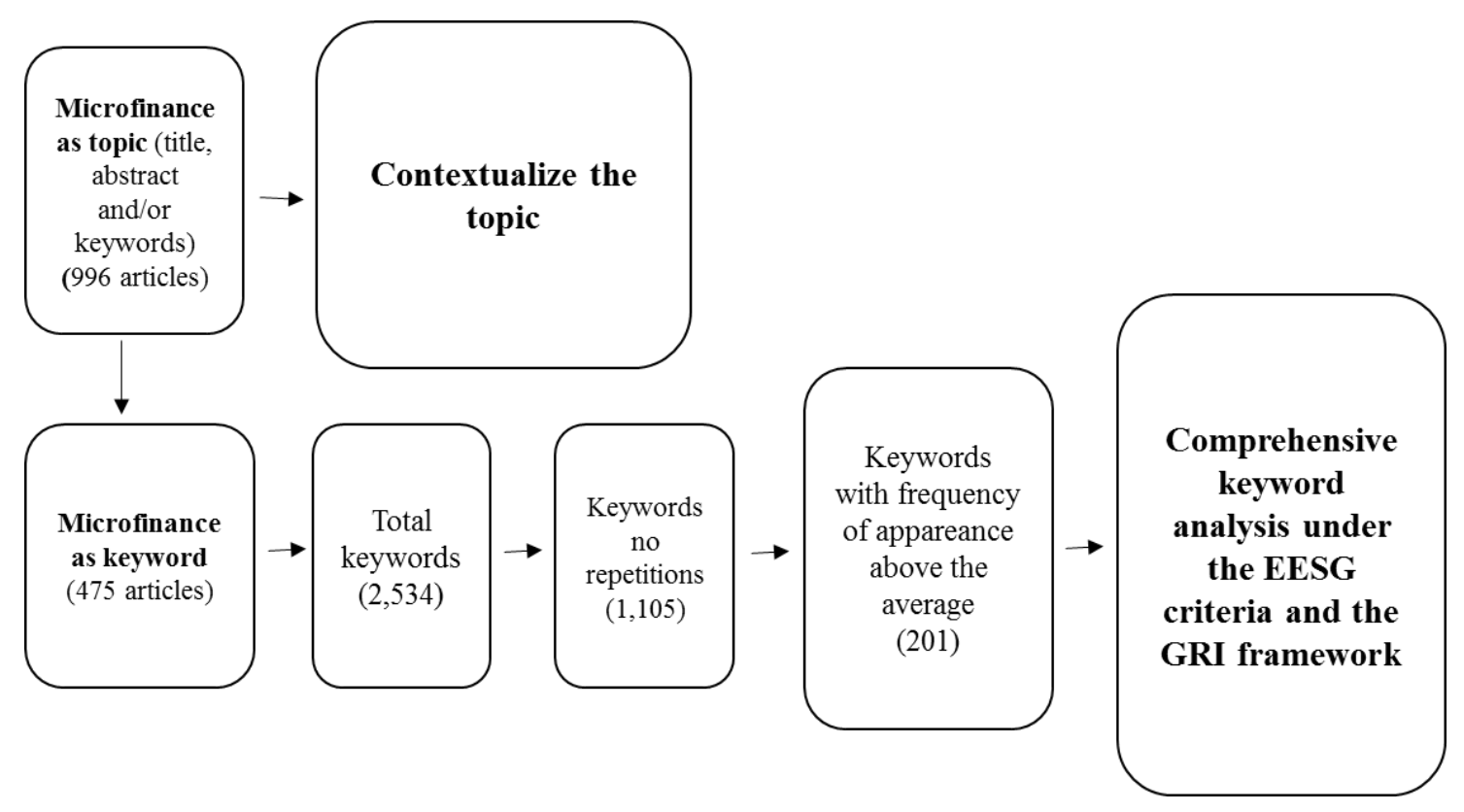

Keywords have been treated as written in the papers in the database; therefore, if a collocation appears, it has been considered as a unique term or concept. In other words, if a sequence of words often co-occurs, e.g., impact evaluation, poverty alleviation or microfinance institutions, as frequently appearing concepts reveal a text's idiosyncrasy the bi-gram is analysed as one term.

Nevertheless, some qualitative normalization of the keywords database has been performed, unifying the plural and the singular (e.g., child labour, children work), removing hyphens (e.g., micro-credit, microcredit), abbreviations relating to its expressions (e.g., SHG, Self-Help Groups), and grouping synonyms or terms that indicate a relationship that is so close that the two terms could be considered to represent a single concept (e.g., HIV, AIDS).

\subsection{Analysis process of the academic literature, methods and indicators}

The analysis process followed to determine the contributions of microfinance sector literature according to EESG criteria and under the GRI framework begins with the 
contextualization of the topic through different bibliometric indicators. Bibliometric analysis method allows us to explore the impact of a field in academic literature using both mathematical and statistical methods (Pritchard, 1969). Such quantitative measures of production of scientific literature are an excellent guide to achieve understanding (Garfield et al., 1978; van Raan, 2005; Granados et al., 2011) in particular levels of specialization (Okubo, 1997) dissemination, and use.

To study the obsolescence of the subject we use the Price and the Half-life indexes, which are designed to measure aging of subject fields and journal literature and also help to discern between slow and fast reception of scientific information (Glänzel \& Moed, 2002). Both indicators use citation analysis to investigate the time when the literature in a particular knowledge area begins to decline and becomes rarely used.

The Price Index is an index of obsolescence that varies depending on the area of knowledge (Price, 1965) and is calculated the percentage of references less than 5 years old of total references. The Half-life Index is 'the time during which one-half of all the currently active literature was published' (Burton \& Kebler, 1960, p. 19) and is calculated by 'subtracting the publication year of the source documents from the median publication year of the documents that cite de source documents' (Diodato \& Gellatly, 2013, p. 77), this is, the Half-life is the year that accumulates the half of the total citations.

After analysing the scientific production at a microfinance topic level, we perform a comprehensive analysis of the keywords to determine to what extent the EESG criteria are reflected in the scholar literature. To do this, first we study the linguistic richness of the microfinance concept and define whether it demands a considerable knowledge of the language to fully understand a text using the type-token ratio (ttr), which is the relation between the number of different words (types) and the total number of words (token) and then, we organize and summarize the data using a data clustering method that maximizes homogeneity within groups and heterogeneity between them.

Before proceeding with the grouping, it is necessary to detect whether there are outliers (Fraley \& Raftery, 1998). Webster dictionary defines outlier as a 'statistical 
observation that is markedly different in value from the others of the sample' and according to Kaufman and Rousseeuw (2009) outliers should be removed before running the clustering method to avoid distortion. In this case, as keywords are grouped based on their frequency of appearance, when terms stand out as outliers due to an extremely high frequency of occurrence they will be isolated as they hinder the proper formation of the rest of the groups but should be studied independently as they constitute the group of most characteristic words or expressions when researching about microfinance.

The cluster analysis was obtained by using IBM SPSS Statistics v.22.0 software package (IBM Corp., Armonk, NY, USA) and the method we choose was the K-means clustering. This method has the objective of clustering a set of $n$ observations into $k$ clusters. This hierarchical algorithm iteratively estimates the cluster means and assigns each case to the cluster with the smallest distance to the cluster mean, grouping objects with high similarity between them in the same group and with low similarity with respect to other groups.

As the k-value is an input parameter, (this is, the number of clusters should be preassigned) to obtain good results is very important a proper determination of this value. That is why we consider run a diagnostic check for determining the number of clusters in the data set. To find the number of groups $(\mathrm{k})$ that minimize the objective function, we used the Elbow method (Throndike, 1953), that looks at the percentage of variance explained as a function of the number of clusters. Percentage of variance explained is the ratio of the between-group variance to the total variance, also known as an F-test which is the ratio of two scaled sums of squares reflecting different sources of variability.

Therefore, once we had defined the groups, to learn more about the terminology in use and to map the relationship between concepts, we applied both word co-occurrence analysis and co-occurrence network methodologies.

Word co-occurrence analysis measures the strength of the relationship between two codes, where the presence of many co-occurrences around the same keyword drifts to a locus of strategic alliance (Ding et al. 2001), revealing patterns and trends in a specific 
discipline (Cambrosio et al., 1993), retaining the essential information and enabling the conversion of data into a specific visual representation (Krippendroff, 2013).

To quantify the intensity of this relationship, we have used the correlation coefficient using ATLAS.ti Scientific Software v.6.2 (GmbH, Berlin, Germany) and applying the following formula:

$$
\mathrm{c}=\mathrm{n}_{12} /\left(\mathrm{n}_{1}+\mathrm{n}_{2}\right)-\mathrm{n}_{12}
$$

where $\mathrm{n}$ is the frequency of appearance and $\mathrm{n}_{12}$ is the co-occurrence frequency of the codes $c_{1}$ and $c_{2}$, whereas $n_{1}$ and $n_{2}$ are each code occurrence frequency. This c-coefficient should vary between zero (when codes do not co-occur) and unity (when two codes always co-occur).

To improve the abstraction of themes in our interpretation of the results, once the ccoefficient of the co-occurrence frequency table had been calculated, the researcher created a data representation, called a co-occurrence network or co-link map. The cooccurrence network shows a map of the collective interconnection of terms based on their paired presence, providing a graphic visualization of both the conceptual framework and the relationships among the concepts.

Co-word analysis and its representation have been used as a relevant method to explore intellectual structures in various fields, including medicine (Rikken et al., 1995; Jensen et al., 2001), politics (Zhou et al., 2005), physics (Bhattacharya \& Basu, 1998; Rafols \& Meyer, 2010), and scientometrics (Callon et al., 1991; Courtial, 1994) among others.

The methodology used to systematically assign and categorize the keywords to each dimension will lead us to four sets based on the meaning and sense of the keywords in terms of their relationship with the economic, environmental, social and governance spheres.

This assignment of keywords to a particular dimension has been carried out under specific selection criteria (Hackston and Milne, 1996), considering its repercussion within 
Microfinance Literature: A Sustainability Level Perspective Survey

a scholarly system of ideas (Aiken \& Williams, 1975) and through a systematic and objective identification of specific categories (Holsti, 1969; Zhang \& Wildemuth, 2009).

To achieve this categorization we have relied on the GRI Sustainability Reporting Guidelines, which offers a frame for preparing sustainability reports by organizations regardless of their size, sector or location (Bouten et al., 2011), where economic, environmental and social issues are included in the specific standard disclosure and governance issues are included in the general standard disclosure. To our knowledge, this is the first attempt to systematise the literature review in this field using a tool that allow us to categorize the literature contributions following a consensual structure.

Following the structure proposed by GRI, the future allocation of keywords will be performed in one of four categories. The economic category includes aspects such as economic performance, market presence, indirect economic impacts or procurement practices. The environmental sphere has information about; inter alia, the use of resources, emissions and environmental grievance mechanisms. The social area is about labour practices, human rights, societal and product responsibility and the governance dimension considering not only the board's structure and composition but also various aspects of its role. For more details, see Figure 3, which describes the various items contained in each area. 
Figure 3. Items contained in the Economic, Enviromental, Social and Governance dimensions according to the GRI guidelines.

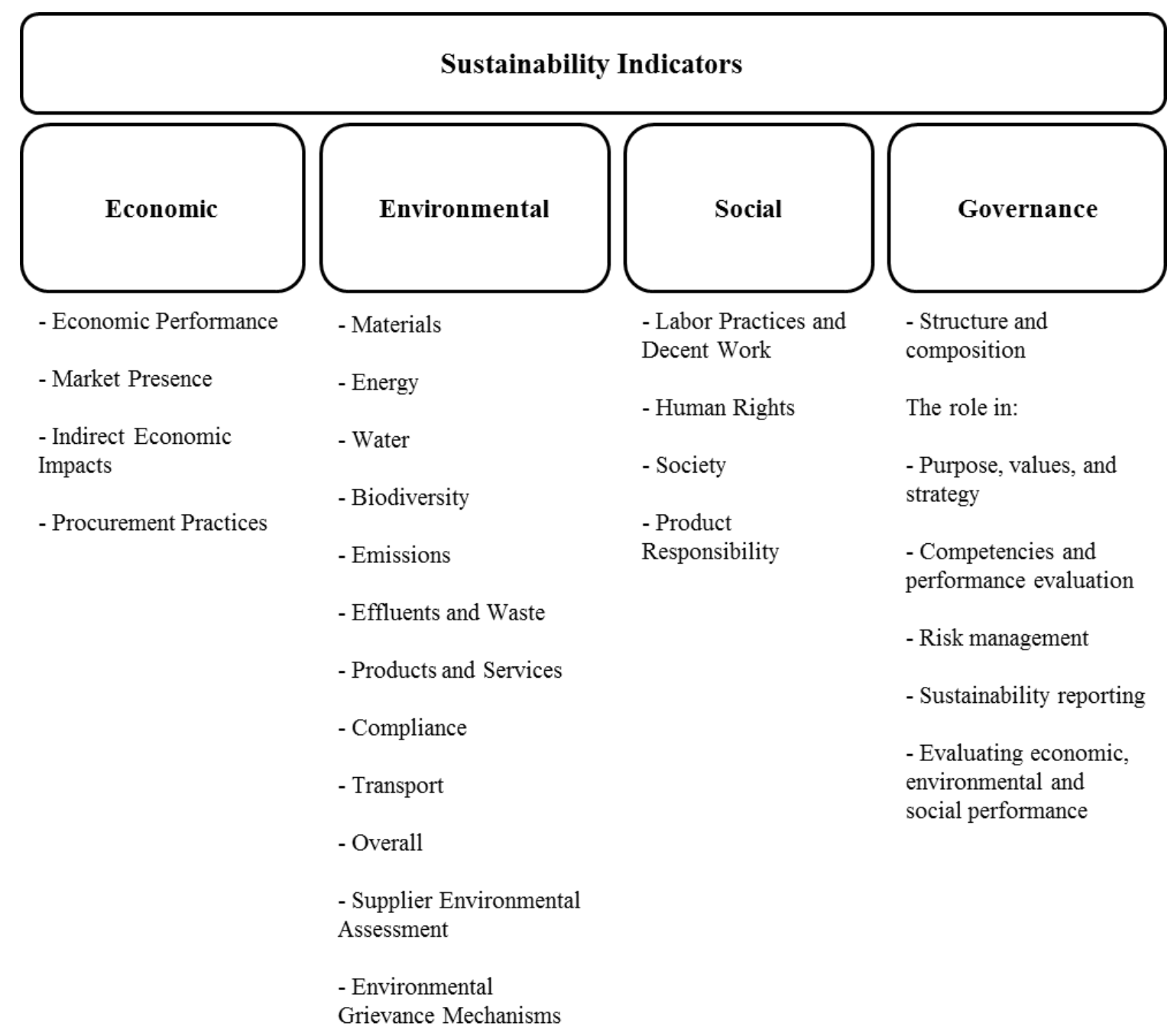

Source: adapted from the G4, GRI Sustainability Reporting Guidelines

Two experts in the field have reviewed every keyword. Academic experts in sustainability, corporate social responsibility, and microfinance assigned each term to a category. When in doubt, the title and abstract of the articles from which keywords had been extracted were examined to contextualize them. In the event of any discrepancy in the classification of a word, a third expert reviewed the relevant keyword (Roman et al, 1999; Moneva et al., 2007). As in other studies of this nature, this paper sought an 
Microfinance Literature: A Sustainability Level Perspective Survey

interpretative analysis to identify meaningful clusters of keywords (Seale et al., 2006) that would describe the economic, environmental, social, and governance dimensions.

\section{Contextualizing the scientific production on microfinance sector}

The strings used in the Web of Science search engine give us the result of 996 articles that contain the term microfinance in the title, abstract or keywords. This sample allows us to describe the scientific microfinance sectoral literature at a topic level ${ }^{1}$.

In terms of production, microfinance publications have risen at an increasing rate since 1997, but were in 2005-the year proclaimed by the United Nations Economic and Social Council as the International Year of Microcredit - and Professor Yunus' Nobel Prize in 2006 when growth augmented noticeably. Figure 4 shows the curve of number of papers increase over the years.

${ }^{1}$ In this section we have considered complete years to make them comparable (until December 2015). The rest of the study includes articles published up to June 2016. 
Microfinance Literature: A Sustainability Level Perspective Survey

Figure 4. The evolution of number of publications per year on microfinance topic $(1997-2015)$

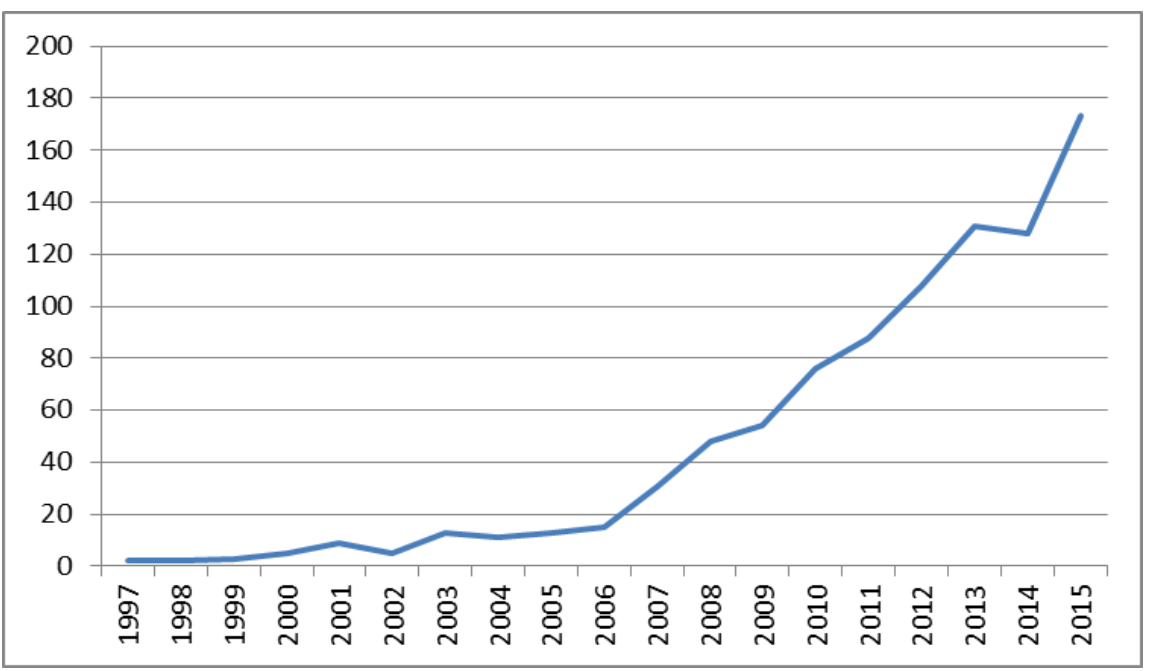

Source: data from the Web of Science Results Analysis section (11/07/2016)

Figure 5 shows the total number of cited references for each year of all articles found with microfinance as topic. As in the case of the number of publications it has an increasing rate since 1997 and with an exponential growth since 2007, with a slight delay in relation to the growth in terms of production.

Figure 5. The evolution of number of citations per year on microfinance topic

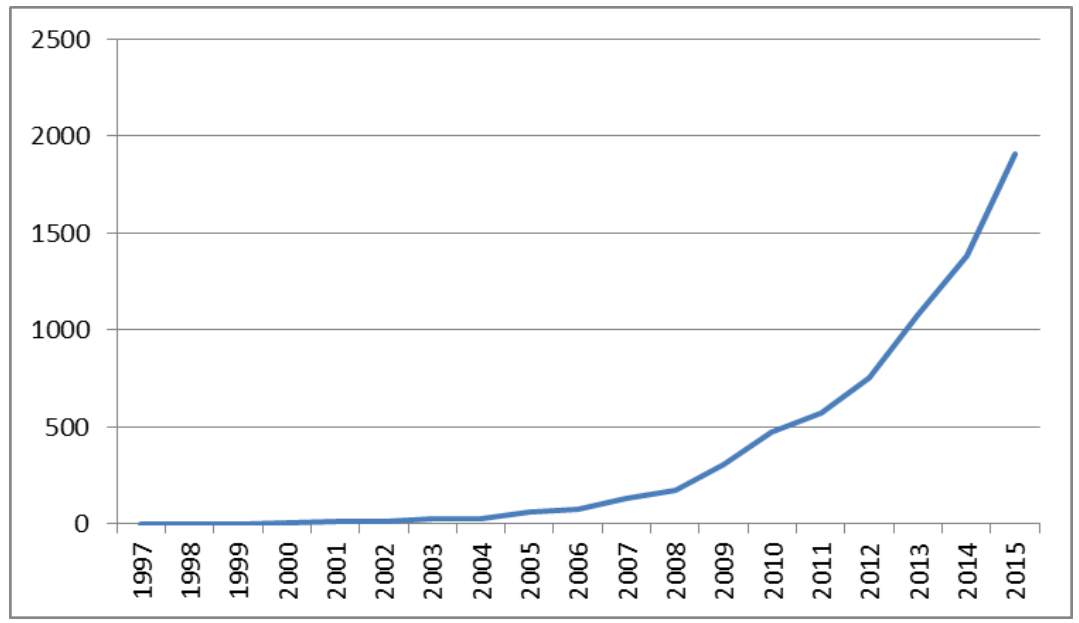

Source: data from the Web of Science Citation Report (11/07/2016) 
Price's index of obsolescence for 2015 indicates that $50 \%$ of the references are less than five years old. A high index indicates that the references correspond to recent documents and therefore is a dynamic subject. In the case of microfinance, this percentage coincides with obsolescence indicated by Price (1965) for the social sciences. Furthermore, its half-life is four years, showing that microfinance is a new subject.

The papers belong to different field research areas. According to the classification used in the source database, the main areas in which microfinance-related studies are published are Business and Economics (54\%) and Public Administration (31\%), whereas the remainder are dispersed among various fields as Social Sciences or Public Environmental Occupational Health. As far as language is concerned $97 \%$ of the papers are written in English and the main contributing countries are USA (38\%), England (14\%) and India $(6 \%)$.

\section{Results: comprehensive analysis of the microfinance sector articles' keywords}

Once described the scientific production at a topic level, we will deepen through a comprehensive analysis of keywords to determine the extent of the contributions of the microfinance sectoral academic research in accordance with the EESG criteria and GRI framework.

Considering the articles where the keyword microfinance is present, almost $33 \%$ of the terms appear once or twice, and the average frequency of appearance is 2.4 times. The type-token ratio (ttr) from 1993 to 2014, date on which a change in trend is observed (see Figure 4), was $53 \%$ and including until June 2016 is $44 \%$. This shows us that there is a considerable dispersion of terminology and that it demands a considerable knowledge of the language to fully understand a text, but the decrease of the ttr including the last year and a half research, indicates that the new additions do not introduce large variations and 
the terms used are very similar. That is, the total number of keywords raise but no the variety.

\subsection{Analysis of keywords groupings}

As explained in Section 2.2. in order to organize the data we have use k-means clustering method. First, to avoid distortion, is necessary to detect whether there are outliers and once isolated, determine the optimum k-value, which is the one that maximizes the percentage of variance explained. In the case of our sample, the Elbow method indicates that the appropriate number of groups is 3 . Table 1 shows the change in the F-value depending on the number of groups $(\mathrm{k})$ and that $\mathrm{k}=3$ has the highest percentage of variance explained.

Table 1. Percentage of variance explained as a function of the number of clusters

\begin{tabular}{|c|c|c|c|c|c|}
\hline K-value & 2 & $\mathbf{3}$ & 4 & 5 & 6 \\
\hline & & & & & \\
F-value & 64.699 & $\mathbf{7 0 . 2 7 2}$ & 61.887 & 47.257 & 37.870 \\
\hline
\end{tabular}

Thus, the result after our clustering process provides us four groups. The first one, the group of keywords with extremely frequency that was isolated to avoid misrepresentation in the cluster analysis and the three groups proposed by the k-means clustering algorithm. Table 2 shows the methods for forming each group, the final distribution of the groups in relation to their frequency of appearance and the subsequent analysis method applied in the treatment of the keywords. 
Microfinance Literature: A Sustainability Level Perspective Survey

Table 2. Distribution of terms according to their group constitution, frequency of appearance and treatment applied.

\begin{tabular}{|c|l|l|c|c|c|}
\hline \multicolumn{1}{|c|}{$\begin{array}{c}\text { Constitution } \\
\text { method }\end{array}$} & \multicolumn{1}{c|}{ Groups } & $\begin{array}{c}\text { Number of } \\
\text { terms }\end{array}$ & $\begin{array}{c}\text { Frequency of } \\
\text { appareance }\end{array}$ & Method for analysis \\
\hline \multirow{3}{*}{$\begin{array}{c}201 \\
\text { keywords }\end{array}$} & \begin{tabular}{l} 
Outlier analysis \\
\cline { 2 - 6 }
\end{tabular} & Extremly high frequency & 5 & $96-27$ & EESG + Co-occurrence \\
\hline & Kery high frequency & 2 & 26 & EESG + Co-occurrence \\
\cline { 2 - 6 } & High frequency & 12 & $25-15$ & EESG + Co-occurrence \\
\cline { 2 - 6 } & Moderate frequency & 182 & $14-3$ & $\begin{array}{l}\text { EESG and GRI } \\
\text { category assignment + } \\
\text { Co-occurrence }\end{array}$ \\
\hline
\end{tabular}

\subsubsection{Terms with extremely high appearance frequency}

This group contains the terms associated with the microfinance concept in the scientific literature whose frequency is well above average, with a rate between 96 and 27. This means that in a paper about microfinance, the terms that most frequently appeared are as follows: poverty, microcredit, microfinance institutions or MFIs, impact evaluation, and poverty alleviation.

Figure 6 shows the relationship between these concepts. The larger the size of the word, the higher the frequency of occurrence; whereas through the correlation coefficient, the thickness of the line states the strength of the connection. 
Figure 6. Map of the terms with an extremely high appearance frequency

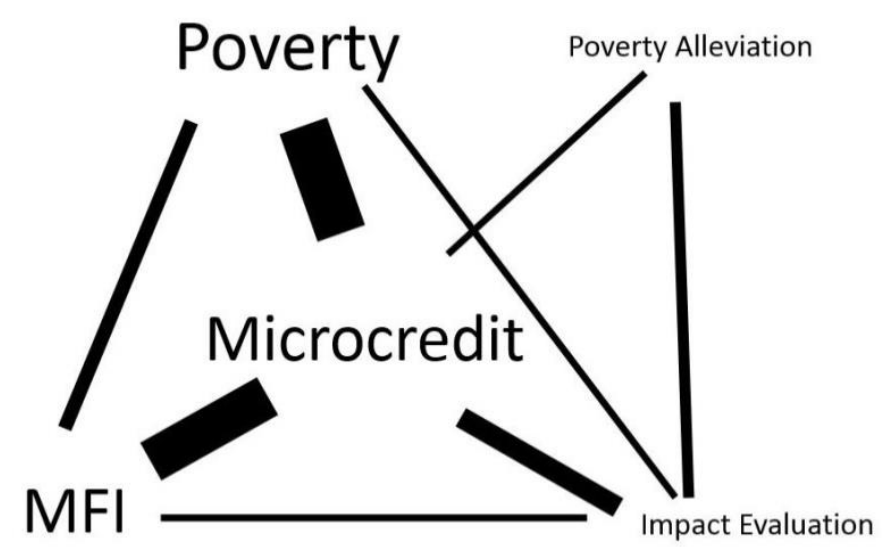

An inter-related group with its centre in microcredit is generated, with the most powerful ramifications for poverty, MFI, and impact evaluation.

Sometimes the terms microfinance and microcredit are treated as synonymous, generating confusion. This situation is partly attributable to the high thrust and popularization of the sector that can be credited to Professor Muhammad Yunus, who first associated the terms microcredit and poverty (Yunus, 1999) and his work had a remarkable impact after he won the Nobel Peace Prize in 2006.

As the map shows and the above confirms, poverty and microcredit are the key terms associated with microfinance, and both terms have the highest correlation in the group. The papers in which the co-occurrence of these terms appear address microfinance from two perspectives. One view focuses on both the effect of loan provision in households and the purpose of obtaining conclusions supported by empirical evidence (Morduch, 1999; Mills, 2007, Joakim \& Wismer, 2015); whereas the other focuses on an economic and political standpoint in which microfinance schemes provide a method for effecting global liberalization of the financial sector consistent with neoliberal visions of development (Weber, 2004; Weber, 2014). 
Throughout these years, significant resources have been devoted to encouraging micro-credits, including the provision of donor funds and grants (Srnec et al., 2011). According to the OECD (2014) database, in 2010 the total net amount of official development aid (ODA) disbursement from all donors to developing countries reached its highest real level ever, increasing to USD 129 billion, and totalling USD 2.5 trillion over 50 years. It is unsurprising that the scientific literature not only portrays a growing interest in MFIs that commercialize their products and services but also attempts to measure assessments of their impact (Agha et al., 2004; Larrú, 2008; Kono \& Takahashi, 2010; Takahashi et al., 2010; Kiiza \& Pederson, 2012; Banerjee, 2013: Deininger \& Liu, 2013; Duflo et al., 2013; Liket et al., 2014).

Here, we must specify there is a caveat to the above observation: this group of terms is composed of the terms that are most immediately related to microfinance and have achieved the status of identity signs. Nevertheless, although these terms are the most often referenced, they relate to concepts that are too broad to provide any specific and detailed information from a sustainability standpoint and it is difficult to categorize them in a single EESG dimension.

\subsubsection{Terms with very high appearance frequency}

Two terms-outreach and gender-define this group. They have an appearance frequency of 26. Although these terms' appearance frequency is the same, the relationship between them is weak. These two words do not often appear together. To confirm the weakness in the relationship between these terms, the term women was added to gender to check whether new relationships were established. The result was that no new relationship appeared between the terms.

The most frequent co-occurrence with gender is that of development; i.e., when research on microfinance and gender is undertaken, it explores the potential effect of microfinance on the development of gender (Johnson, 2005; Rohatynskyj, 2011; 
Microfinance Literature: A Sustainability Level Perspective Survey

Maclean, 2012; Warnecke, 2014) or the opposite case, the effect of refusing microfinance loans (Chaudhry, 2016).

The term that most frequently co-occurs with outreach is sustainability and to a lesser extent, mission drift. When the bi-gram outreach-sustainability is established, we researched whether there was a trade-off between sustainability and outreach and how the two concepts were important to MFI funders when inter-related (Bassem, 2009; Gutiérrez-Nieto \& Serrano-Cinca, 2009; Hermes et al., 2011; Hermes, 2014). It should be noted that in this case, sustainability refers to financial sustainability because it addresses whether MFIs were profitable enough to maintain and expand their services in the absence of subsidies (Rosenberg, 2009).

When there is a relationship between outreach and mission drift, the research focuses on establishing which environment is the most successful in avoiding mission drift (Vanroose \& D'Espallier, 2013; Kar \& Swaim, 2014; Serrano-Cinca \& Gutiérrez-Nieto, 2014).

Although there is a weak relationship between the high co-occurrence bi-gram of outreach-gender and the terms could be vague to categorize them according to the EESG criteria, taking into account their strongest relationships we can consider that the economic dimension is present when the research is about outreach and financial sustainability, social aspects when gender and development appear together and socioeconomic issues when the investigation is about the mission drift when 'social performance assessment and management have failed to achieve the same clarity, consistency, and level of acceptance as financial performance assessment and management' (Copestake, 2007, p. 1722). 


\section{Microfinance Literature: A Sustainability Level Perspective}

Survey

\subsubsection{Terms with a high appearance frequency}

In this group, the terms with greater frequency are development and microenterprise, followed by social capital and women. Figure 7 shows the inter-relationship between these terms.

Figure 7. Map of terms with a high frequency of appearance

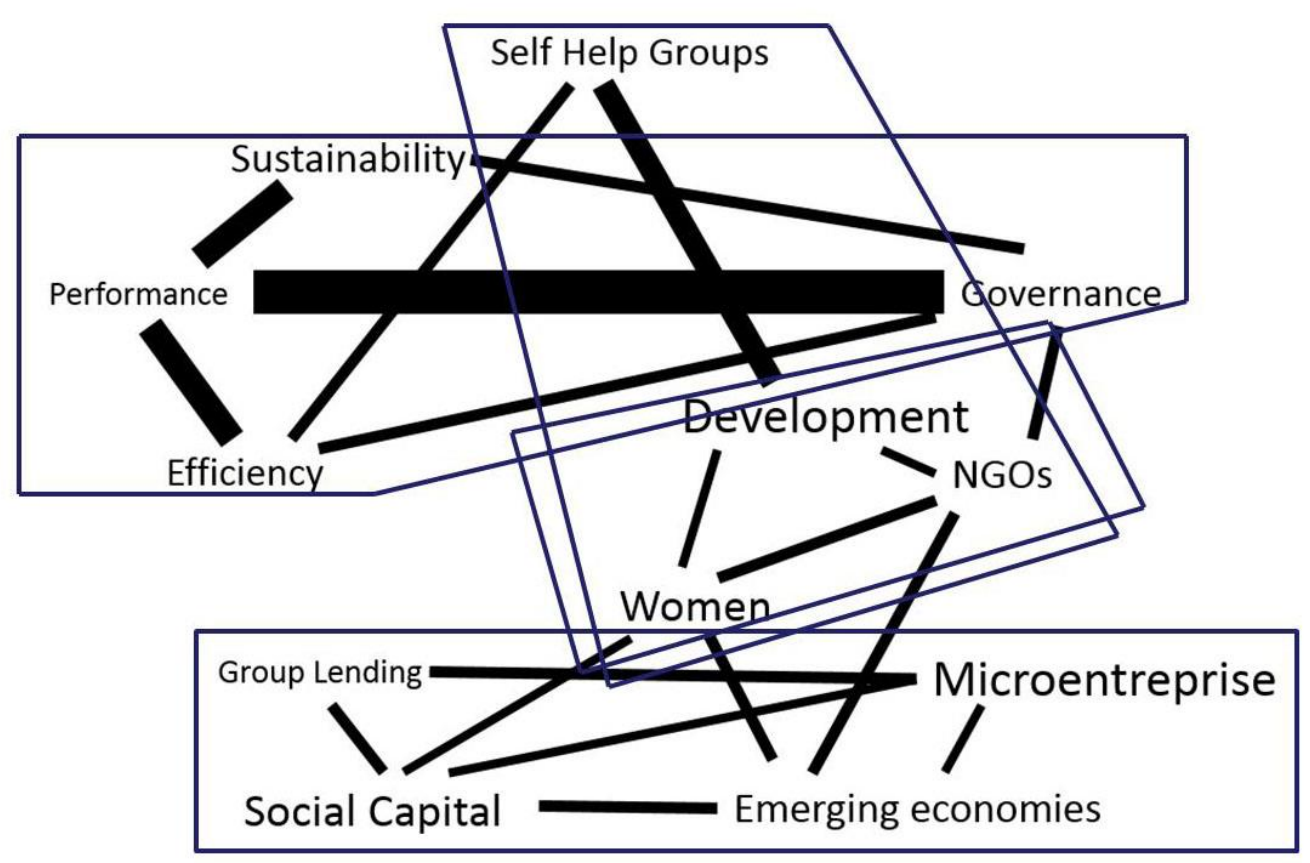

Development is the most strongly related to self-help groups. In the papers in which this co-occurrence appears, the researched topic focuses both on the implementation of socio-economic development programmes and on the evaluation of the impact of such projects on their intended result of empowering poor, rural women (De' \& Ratan, 2009; Rohatynskyj, 2011; Antoniello, 2015; Sahu, 2015).

Accordingly, although there is a relationship between the two terms, self-help groups is a transversal concept. The direct relationship is between microfinance projects and the 
study of their impact; there, the term self-help groups emerges as a type of programme designed for village-based financial intermediary committees.

Development is also related to NGOs and women, creating an inter-related group that is found in papers that study microfinance as a development instrument, aspire to appraise the adequacy of NGOs' structure and activities related to microfinance programs, and drafting papers on the role of women as economic instruments, i.e., members of peer group lending schemes. That is, development is not associated with gender, but with microfinance as a tool for progress (Srnec et al., 2011; Smith, 2012; Schuster, 2014).

In addition to the fact that social capital and microenterprise interact with each other, these terms share co-occurrence with emerging economies and lending group. In the cases that we examined, two research lines using this group of concepts were observed: (1) those that treated debt repayment; and (2) those that aspired to explain how the provision of microfinance can result in both new venture creation and the growth of the existing business base (Heino, 2006; Boehe \& Cruz, 2013; Giné \& Karlan, 2014; Newman et al., 2014).

The term performance, although not noted for its frequency, provides strong cooccurrence relations when it is visible. When it appears, it therefore relates very directly to governance, efficiency, and sustainability. The highest correlation coefficient in this group is obtained by the bi-gram formed by the keywords performance and governance. Overall, the scientific literature that addresses these two aspects seeks to establish a relationship between governance-mechanisms and MFI performance through its board size and composition, the regulatory environment, and competition (Hartarska \& Mersland, 2012; Kim, 2014); outreach that stems from the lending methodology (Bassem, 2009; Mersland \& Strøm, 2009); the influence of the lender's level of transparency, and standards of good practices (Augustine, 2012; Waweru \& Spraakman, 2012; Barry \& Tacneng, 2014).

When related to efficiency, the studies normally examine the relationship between the firm's performance and the increase in its efficiency or financial results (Barry \& 
Tacneng, 2014; Bos \& Millone, 2015; Azad et al., 2016); as in the previous bi-gram, attention is devoted to the governance mechanisms, the board size and composition, and the effect of competition and regulatory environments (Hartarska \& Mersland, 2009); the MFI's goal definition (Amersdorffer et al., 2014); and even the effect of religion (Mersland et al., 2013; Tower, 2016).

Sustainability emerges as a goal or objective. In previous studies, the study of the performance, the application of governance mechanisms, and the evaluation of efficiency suggested the need to find ways and tools that ensure sustainability. Although recent incorporations begin to conceptualize sustainability in a holistic manner (Bhanot \& Bapat, 2015), the term sustainability is used from a strictly financial point of view, linking MFIs' sustainability with both their profit and their long-term existence.

At this point, it is observed that the main line of research relates to the economic dimension but also the governance sphere emerges as the mechanisms to achieve the efficiency in performance that could ensure MFIs' financial sustainability.

\section{Discussion: contributions of microfinance sectoral literature to sustainability}

Thus far, we have contextualized the scientific production on microfinance and explored the most common terminology to discover which issues are the most recurrently researched. We have observed that those keywords with an extremely high appearance frequency are too broad and imprecise concepts to categorize them in a particular EESG dimension. Keywords with a very high frequency relate to economic and social issues and the group with high frequency of appearance concern mainly to economic subjects and to a lesser degree governance.

To determine to what extent microfinance sectoral scientific literature is contributing to sustainability from an inclusive perspective that involves the EESG dimensions, we have assign the 182 keywords with a moderate frequency of appearance (between 14 and 
3) to a particular EESG dimension following the method explained in Section 2.2. and then we have study the relations of both intragroup and intergroup for each dimension using the GRI Sustainability Reporting Guidelines as reference pointing out the matters that are researched as well as those that have not yet so far been approached.

When the scientific community investigates microfinance, it does so primarily in economic terms: $51 \%$ of the terms used as keywords correspond to this area, followed by $33 \%$ of the terms of a social nature and to a lesser extent, keywords related to corporate governance and environmental issues, both with an $8 \%$ of presence. In addition to considering the amount of papers, the analysis takes into account the strength or weakness of the relationships established between concepts, considering the correlation coefficient calculated as indicated in Section 2.2. Table 3 offers the percentage of papers interrelating dimensions and the intensity of the correlation between concepts.

Table 3. Percentage of papers of each EESG pair combination of dimensions and the intensity of the relationships established.

\begin{tabular}{|l|c|}
\hline EESG inter-relationship (sorted by \% of papers) & $\%$ \\
\hline Economic-Economic & $35 \%$ \\
\hline Economic-Social & $28 \%$ \\
\hline Social-Social & $15 \%$ \\
\hline Economic-Environmental & $7 \%$ \\
\hline Economic-Governance & $6 \%$ \\
\hline Social-Environmental & $2,5 \%$ \\
\hline Governance-Governance & $2,5 \%$ \\
\hline Social-Governance & $2 \%$ \\
\hline Governance-Environmental & $2 \%$ \\
\hline Environmental-Environmental & $1 \%$ \\
\hline
\end{tabular}

\begin{tabular}{|l|l|}
\hline \multicolumn{2}{|c|}{ Color coding } \\
\hline & Very strong relation \\
\hline & Strong relation \\
\hline & Moderate relation \\
\hline & Weak relation \\
\hline & Very weak relation \\
\hline
\end{tabular}

The most common relationship is given in papers of economic terms that relate to others of the same category (35\%), followed by those articles that relate social with economic aspects $(28 \%)$. In both cases the relationship between concepts is very strong. In $15 \%$ of the papers the relationship is established between concepts of the social sphere 
Microfinance Literature: A Sustainability Level Perspective Survey

with a strong relationship. The percentage of papers where economic terms are related to environmental or governance aspects is very similar (7\% and $6 \%$ respectively); however the intensity of the relation differs: in the first case the relation is weak and in the second is moderate. When it comes to social matters, these are related to environmental issues in a $2.5 \%$ with a very weak relationship between expressions, and in $2 \%$ with governance with weak correlation. The concepts of governance relate to others of the same category in a scant $2.5 \%$ of the time, but with a moderate correlation. Lower co-occurrences are given between environmental terms (1\%) and environmental terms combined with governance (2\%) and also with very weak and weak correlation respectively.

To integrate the EESG dimensions and the scientific literature, according to Lozano (2012), we have code the different GRI categories with respect to the microfinance sectoral academic research and its contribution to sustainability. Table 4 shows which issues are addressed and which topics are missing. 
Table 4. Analysis of the contributions of microfinance sectoral literature to sustainability under the GRI framework considering the issues addressed.

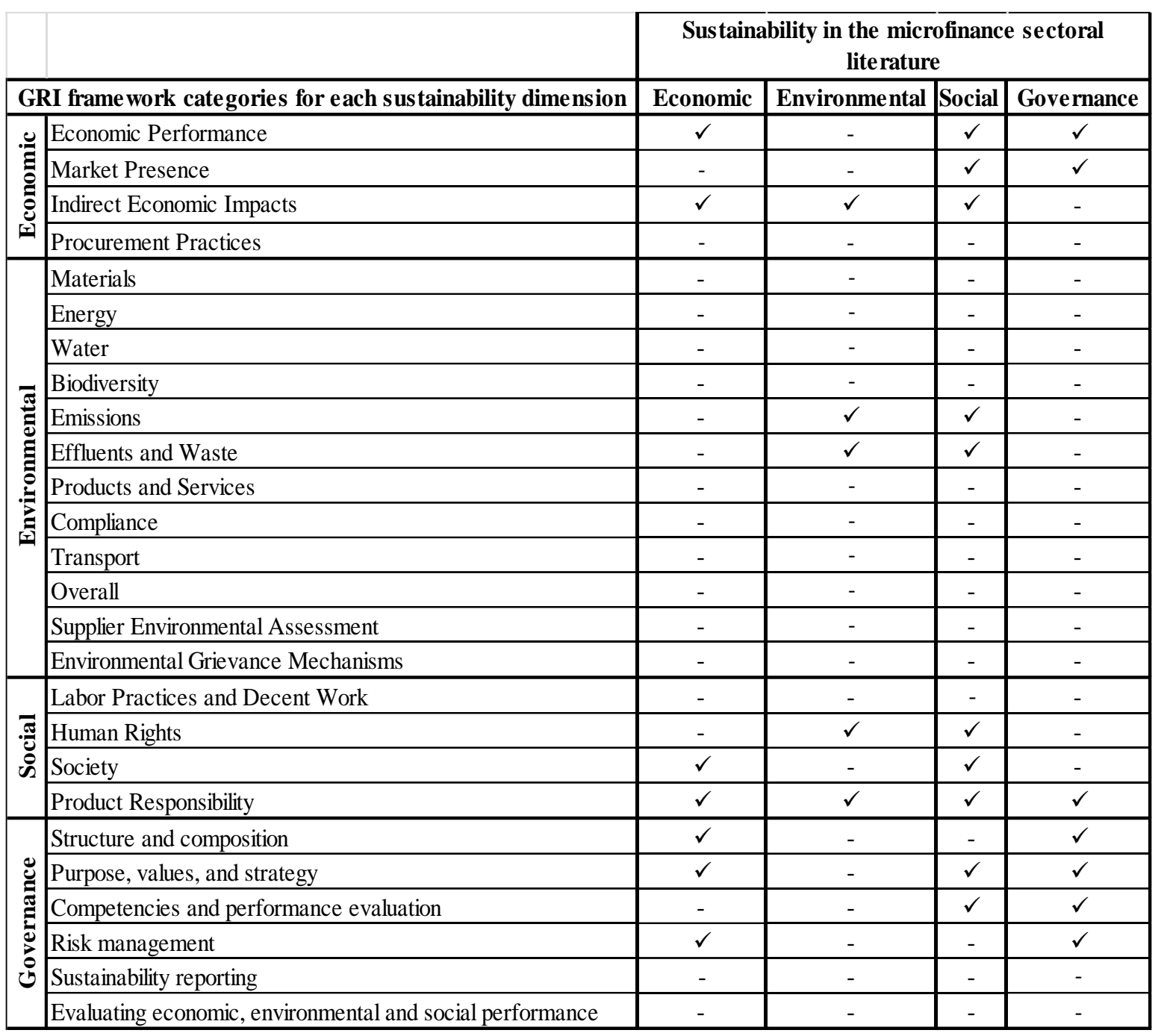

\section{Code: $\checkmark$ Presence - Absence}

Then the results obtained from the analysis of the literature and using the GRI framework as a reference are presented. It will be shown that the economic and social dimensions feature a high production of texts that discuss a relatively wide variety of issues. The environmental dimension features both a very small number of papers and very generic information processing. The governance dimension features a variety of topics but very low production and that there is no balance among economic, social, 
environmental and governance dimensions in the academic literature on the microfinance sector. The results also will highlight the main missing areas in which to date has been investigated little or nothing.

\subsection{The economic dimension and their inter-relationships}

It is noted that in the economic dimension, economic performance and indirect economic impacts are the two most developed sections in the literature on the microfinance sector. Economic performance addresses issues such as investment performance, operational costs, interest rates, subsidies, donations, financial assistance received from governments, and financial sustainability. Indirect economic impacts include the impact evaluation of the products and services of the various microfinance programmes in development and poverty alleviation. Although this impact assessment is categorized in the economic section, it is closely related mainly to the results of the social area.

The connection of concepts with a higher correlation coefficient when the relationship is intragroup is shown in Figure 8.

Figure 8. The most closely related economic terms

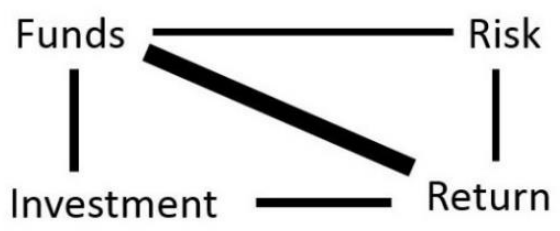

These papers investigate the investment performance of microfinance investment funds, their global risk, and their returns (Augsburg, 2009; Janda \& Svárovská, 2010), along with the correlation of the dependence of these funds' returns on the performance 
of stock and fixed income markets when compared to benchmark market indices (Janda \& Svárovská, 2013).

The other economic terms that show a strong correspondence are as follows: informal finance, which is present in the research on the reasons for the persistence of informal finance despite governmental attempts to increase credit availability and eliminate reliance on usurious financing (Tsai, 2004); and rural finance, informal finance and interest rates, all of which are found in the search for the relationship between formal and informal markets and the impact of microfinance programmes on the interest rates charged by moneylenders (Harper, 2012; Mallick, 2012). A third bi-gramcorrespondent banking and branchless banking - has been found in a study of financial inclusion and how this type of banking is helping downscale financial services, resulting in the establishment of successful partnerships with local MFIs (Diniz et al., 2014).

In these three cases, even considering that the correlation is between strictly financial concepts, the spirit of the articles has a strong social vocation that considers, among other objectives, the relationship between the characteristics of the microfinance system and financial inclusion.

In the articles analysed, there is no reference to procurements practices or market presence, which is defined in the GRI guide as ratios of standard entry-level wage by gender or proportion of senior management. In the various investigations, market presence is related to corporate structure, outreach and the IMF target market. The most noticeable absence occurs in the lack of connection between the papers of economic content with respect to environmental impacts.

\subsection{The environmental dimension and its inter-relationships}

Although environmental issues are increasing their presence, especially in recent years that has raise from $1 \%$ in 2014 to $8 \%$ in 2016, is still one of the least often addressed dimensions in the microfinance sectoral literature. It presents the lowest frequencies of 
appearance and correlation coefficients both intra-group level and in connection with the other areas.

The very sparse presence of environmental concepts is especially remarkable considering that the environmental field has been one of the major drivers of the sustainability term (Tilbury, 1995; Dovers, 2005) as an essential third axis (along with the social and economic axes). Whereas in other sectors, sustainability is usually related to environmental aspects, in the case of the microfinance sector, it is virtually impossible to find a paper in which the term sustainability does not refer to financial sustainability.

It is possible that few authors have addressed microfinance from an environmental perspective because an MFI's activity does not directly generate a high environmental impact in terms of resource use, energy consumption, transport or emissions. However, activities financed by MFIs can have a high impact on biodiversity, pollution and waste generation (Allet, 2011) because MFI-financed businesses are often developed outside the regulatory framework (Nishat, 2004; van Elteren, 2007; Hall et al., 2008).

Organizations such as Microfinance Information Exchange, Inc (MIXMarket) consider this feature when evaluating MFIs, which distinguishes whether an MFI considers the environmental impact of the activity to be developed when granting a loan and whether their customers are penalized for developing activities that damage the environment. However, this type of valuation is not reflected in the scientific literature and research on this issue is included in a very small number of papers that usually refer to very broad and generic aspects such as ecological responsiveness, environmental motivation or green and do not address specific actions and consequences.

\subsection{The social dimension and their inter-relationships}

In the GRI framework, the social dimension includes labour practices and decent work and concerns aspects such as employment conditions, health and safety, occupational training and education, and diversity and equal opportunity, among others. 
The academic research focuses more on the social consequences of microfinance than on the direct effect on the MFI itself. Therefore, there is research on training and education, health and safety, and equal opportunities resulting from the implementation of microcredit programmes (Ssewamala et al., 2010; Bahng, 2013; Bairagi \& Azzam, 2014).

In the product responsibility section, we must consider the type of business that the IMF operates. Accordingly, when GRI mentions product and service labelling, we must consider it as the quality of information about a product or service that is provided to customers, for example, interest rates and the method used for their calculation, the establishment of self-help groups and repayment conditions and loan recovery practices, among others. The literature shows the debate about the suitability of the application of a particular calculation method (González, 2010) and above all, over-indebtedness (Rahman, 1999; Hudon, 2009) as one of the primary issues associated with product responsibility in this sector.

Papers that address human rights are primarily focused on child labour (Landmann \& Frölich, 2015; Chakrabarty, 2015), non-discrimination and more specifically, on women's empowerment. These papers dwell on the impact of microfinance programmes on women's economic well-being and empowerment, relating on the one hand to gender violence and HIV prevention and on the other hand to children's nutrition and health. These studies conclude that interventions that address women's economic and social vulnerability could contribute to reductions in HIV risk behaviour (Pronyk et al., 2008; Dworkin \& Blankenship, 2009) and that the presence of MFIs in communities significantly improves children's health and nutrition (DeLoach \& Lamanna, 2011) and establish a connection between MFI interventions and the generation of positive ethical strength in negative contexts such as high-level poverty and women's powerlessness (De' \& Ratan 2009; Rohatynskyj, 2011; Chakrabarty \& Bass, 2014) to determine repayment capacity (D’Espallier et al. 2011).

Society section is primarily reflected in the literature by research that treats the impact of programmes on local communities (Schreiner \& Woller, 2003; Smets, 2006; Parvin \& Shaw, 2013) and indigenous rights (Fomba, 2008; Ferguson, 2010). 
Although the social sphere is widely investigated in microfinance, there are still areas with little information as are the implications of Human Rights with regard to governance, as well as the implications of microfinance in the society from the environmental and governance point of view.

\subsection{The governance dimension and its inter-relationships}

In this area, must be considered that the number of articles is very limited but that the literature on governance issues is diverse and the co-occurrence correlation shows a moderate connexion intra-group and a strong link with economic matters.

Structure and composition, purpose, values and strategy, competencies and performance evaluation and risk management are discussed, generally, in studies that aim to improve financial performance and outreach. On the one hand, studies that address the governance dimension attempting to establish the relationship between the performance and governances mechanisms (e.g., board characteristics, CEO compensation, or various types of firm ownership) (Hartarska \& Nadolnyak, 2007; Hartarska \& Mersland, 2012; Mersland et al., 2013; Saj, 2013; Amersdorffer et al., 2014), considering either the cost of such mechanisms (Mersland, 2009) or how institutions allocate surplus to stakeholders (Périlleux et al., 2012). And on the other hand, but to a lesser extent, papers that examine the effect of MFI competition and regulations on their outreach and financial performance (Cull et al., 2011).

The scientific community has not dwelt upon the corporate governance-microfinance pairing holistically. Its foremost objective has been to improve MFIs' financial performance, typically reaching conclusions that involve the need to implement both good governance practices (Rock et al., 1998; Helms, 2006; Mersland \& Strøm, 2009) and better regulation for MFIs (Christen et al., 2003; Hartarska \& Nadolnyak, 2007). The current sectoral literature on microfinance does not reflect the role of governance in the triple bottom line evaluation or sustainability reporting. 
Once the findings of the studies were presented, we found that there is no balance among the EESG dimensions in the academic literature on the microfinance sector. This unbalanced among the different areas, it is not exclusive of the microfinance literature. As Crifo and Forget (2015) point out, in the case of Corporate Social Responsibility financial analysis prevails over social or how the environmental dimension has led the concept of sustainability in most areas (Tilbury, 1995; Dovers, 2005). That is, the four EESG criteria are important, but the context in which they operate determines their relevance and grants different weights to each one.

In this sense, although it can be considered that microfinance industry is established at the bottom of the pyramid and the main goals could be related to social and economic aspects, in our opinion, further research should be done in those areas where it has been detected major gaps in the literature. Consistent with prior research, more empirical evidence on MFIs' environmental performing is demanded (Hall et al. 2008; Allet \& Hudon, 2015; Serrano-Cinca et al. 2016), also greater attention to governance mechanisms (Hartarska, 2009; Beisland et al. 2015; Mori et al. 2015) and an holistic approach in the study of sustainability, once some minimal favourable social conditions are achieved (Haughton, 1999; Moran et al., 2008; Saint-Supéry et al., 2014).

\section{Conclusions}

This paper contemplated an inclusive framework to analyse the contribution of microfinance sectoral scholarly research according to the EESG criteria and the GRI structure, relied on a systematic review of an extensive and growing literature of high academic impact journals. First, regarding terminology, we surveyed how the main concepts discussed, primarily link microfinance to microcredit, MFIs, and the evaluation of their impact, especially in relation to their effect on poverty alleviation, development, and financial inclusion. These investigations seek to improve the performance of the microfinance projects and its welfare impact. Second, there is a clear asymmetry among various areas of study; economic and social fields tend to have more of a presence 
(described in Table 3) and consider a greater variety of issues. Third, studies on environmental and governance matters have been most often set aside and the interrelation with other areas are lacking (identified in Table 4). This study furthers the undertaking of investigation in a comprehensive fashion and proposes the scientific research production as the beacons of change to lead this the challenging process of implementing a sustainability analytical framework, in order to promote synergies and trade-offs among economic agents, policymakers, and academics that encourage the development of sustainability management in microfinance sector.

\section{References}

Agha, S., Balal, A. and Ogojo-Okello \& Ogojo-Okello, F. (2004) The impact of a microfinance program on client perceptions of the quality of care provided by private sector midwives in Uganda. Health Services Research Journal, 2004 December; 39, 6 Pt 2: 2081-2100. DOI: 10.1111/j.1475-6773.2004.00333.x.

Aiken, L. and Williams, T.M. (1975) Development of Multiple Dimension Use in Form Classification. Child Development, Vol. 46, no. 1: 123-132.

Allet, M. \& Hudon, M. (2015) Green Microfinance: Characteristics of Microfinance Institutions Involved in Environmental Management, J Bus Ethics, 126:395-414.

Allet, M. (2011) Measuring the environmental performance of microfinance. CEB Working Paper N11/045, Bruxelles, Centre Emile Berheim, 2011.

Amersdorffer, F., Buchenrieder, G., Bokusheva, R. and Wolz, A. (2014) Efficiency in microfinance: Financial and social performance of agricultural credit cooperatives in Bulgaria. Journal of the Operational Research Society, 66: 57-65. DOI: 10.1057/jors.2013.162.

Antoniello, P. (2015) Banking the Unbanked: Women and Microfinance in India. Urbanities, Vol. 5, No 1, pp 63-71.

Armendáriz de Aghion, B. \& Morduch, J. (2005). The Economics of Microfinance, Massachusetts Institute of Technology.

Augsburg, B. (2009) The impact of a dairy intervention in rural India: Evidence from 
realised outcomes and expected returns to investment. Journal of Development Effectiveness, June 2009, v. 1, no. 2: 147-170.

Augustine, D. (2012) Good practice in corporate governance transparency, trust, and performance in the microfinance industry. Business Society, December 2012, vol. 51, no. 4: 659-676. DOI: 10.1177/0007650312448623.

Azad, M. A. K., Masum, A. K. M., Munisamy, S., \& Sharmin, D. F. (2016). Efficiency analysis of major microfinance institutions in Bangladesh: a Malmquist index approach. Quality \& Quantity, 1-13.

Azapagic, A. (2004) Developing a framework for sustainable development indicators for the mining and minerals industry, Journal of Cleaner Production, Vol.12, Issue 6, pp 639-662.

Bahng, G. (2013) Mitigating social exclusion in microlending: A case study of wisdom microfinance institution in Ethiopia. Journal of International Development, 25: 3144. DOI: $10.1002 /$ jid.1848.

Bairagi, S. and Azzam, A (2014) Does the Grameen Bank exert market power over borrowers? Applied Economics Letters, Vol. 21, Issue 12.

Bakker, A., Schaveling, J. and Nijhof, A. (2014) Governance and microfinance institutions. Corporate governance. The International Journal of Business in Society, Vol. 14, Issue 5: 637-652. DOI: http://dx.doi.org/10.1108/CG-03-2014-0032.

Banerjee, A.V. (2013) Microcredit under the microscope: What have we learned in the past two decades, and what do we need to know? Annual Review of Economics, Vol. 5: 487-519.

Barry, T.A. \& Tacneng, R. (2014) The Impact of Governance and Institutional Quality on MFI Outreach and Financial Performance in Sub-Saharan Africa, World Development, Vol. 58, pp. 1-20.

Bassem, B.S. (2009) Governance and performance of microfinance institutions in Mediterranean countries. Journal of Business Economics and Management 01/2009 10 (1). DOI: 10.3846/1611-1699.2009.10.31-43.

Beisland, L.A., Mersland, R., Strøm, Ø (2015) Audit Quality and Corporate Governance: Evidence form Microfinance Insdustry, International Journal of Auditing, 19: 218237. 
Bhanot, D., \& Bapat, V. (2015). Sustainability index of micro finance institutions (MFIs) and contributory factors. International Journal of Social Economics, 42(4), 387-403.

Bhattacharya, S. and Basu, P. (1998) Mapping a research area at the micro level using coword analysis. Scientometrics, Volume 43, Issue 3: 359-372. DOI: 10.1007/BF02457404.

Boehe, D.M. and Cruz, L.B. (2013) Gender and microfinance performance: Why does the institutional context matter? World Development, Volume 47, July 2013: 121135.

Boons, F.A.A. \& Lüdeke-Freund, F. (2013) Business models for sustainable innovation: State-of-the-art and steps towards a research agenda. Journal of Cleaner Production, 45, 9-19.

Bos, J. W., \& Millone, M. (2015). Practice what you preach: Microfinance business models and operational efficiency. World Development, 70, 28-42.

Bouten, L., Everaert, P., Van Liedekerke, L., De Moor L. \& Christiaens, J. (2011) Corporate social responsibility reporting: A comprehensive picture? Accounting Forum, Vol. 35, Issue 3: 187-204.

Braat, L. (1991) The predictive meaning of sustainability indicators, In Search of Indicators of Sustainable Development, vol.1 of Environment \& Management pp 5770. Springer.

Brau, J.C. and Woller, G.M. (2004) Microfinance: A comprehensive review of the existing literature. Journal of Entrepreneurial Finance, Vol. 9, no. 1: 1-27.

Brown, B., Hanson, M., Liverman, D. and Merideth Jr., R. (1987) Global sustainability: Toward definition. Environmental Management, Volume 11, Issue 6: 713-719.

Brundtland, G. H. (1987). Our common future: Report of the 1987 World Commission on Environment and Development. United Nations, Oslo, 1-59.

Burton, R.E. and Kebler, R.W. (1960) The "half-life" of some scientific and technical literatures. American Documentation, Volume 11, Issue 1: 18-22, January 1960. DOI: 10.1002/asi.5090110105.

Busch, T, Bauer, R. \& Orlitzky, M. (2016) Sustainable Development and Financial Markets: Old Paths and New Avenues, Business \& Society, Vol. 55(3) 303-329

Callon, M., Courtial, J.P. and Laville, F. (1991) Co-word analysis as a tool for describing 
the network of interactions between basic and technological research: The case of polymer chemistry. Scientometrics, Volume 22, Issue 1: 155-205.

Cambrosio, A., Limoges, C., Courtial, J.P. and Laville, F. (1993) Historial scientometrics? Mapping over 70 years of biological safety research with co-word analysis. Scientometrics, 27 (2): 119-143.

Chakrabarty, S. (2015) A Nexus between Child Labour and Microfinance: An Empirical Investigation, Economic papers (Economic Society of Australia) (0812-0439), 34 (12), p. 76.

Chakrabarty, S. and Bass, A.E. (2014) Institutionalizing ethics in institutional voids: Building positive ethical strength to serve women microfinance borrowers in negative contexts. Journal of Business Ethics, February 2014, Volume 119, Issue 4: 529-542.

Chaudhry, V. (2016). Living at the Edge Disability, Gender, and Neoliberal Debtscapes of Microfinance in India. Affilia, 0886109915622525.

Christen, R., Lyman, T. and Rosenberg, R. (2003) Microfinance Consensus Guidelines: Guiding Principles on Regulation and Supervision of Microfinance. CGAP and World Bank, Washington, DC.

Ciegis, R., Ramanauskiene, J. \& Martinkus, B. (2009) The Concept of Sustainable Development and its Use for Sustainability Scenarios, Inzinerine EkonomikaEngineering Economics (2): 28-37.

Copestake, J. (2007). Mainstreaming microfinance: Social performance management or mission drift?. World Development, 35(10), 1721-1738.

Courtial, J.P. (1994) A co-word analysis of scientometrics. Scientometrics, 31(3): 251260.

Crifo, P., \& Forget, V. D. (2015). The Economics of Corporate Social Responsibility: A Firm-Level Perspective Survey. Journal of Economic Surveys, 29(1), 112-130.

Crossan, M. and Apaydin, M. (2010) A multi-dimensional framework of organizational innovation: A systematic review of the literature. Journal of Management Studies, Volume 47, Issue 6: 1154-1191. DOI: 10.1111/j.1467-6486.2009.00880.x.

Cull, R., Demirgüç-Kunt, A. and Morduch, J. (2011) Does regulatory supervision curtail microfinance profitability and outreach? World Development, Volume 39, Issue 6, 
June 2011: 949-965.

D’Espallier, B., Guérin, I. and Mersland, R. (2011) Women and repayment in microfinance: A global analysis. World Development, Volume 39, Issue 5: 758-772.

De', R. and Ratan, A.L. (2009) Whose gain is it anyway? Structurational perspectives on deploying ICTs for development in India's microfinance sector. Information Technology for Development, Volume 15, Issue 4: 259-282. DOI: 10.1002/itdj.20129.

Deininger, K. and Liu, Y. (2013) Economic and social impacts of an innovative self-help group model in India. World Development, vol. 43(C): 149-163.

DeLoach, S.B. and Lamanna, E. (2011) Measuring the impact of microfinance on child health outcomes in Indonesia. World Development, vol. 39(10): 1808-1819.

Ding, Z.L., Yang, S.L., Hou, S.S., Wang, X., Chen, Z. and Liu, T.S. (2001) Magnetostratigraphy and sedimentology of the Jingchuan red clay section and correlation of the Tertiary Eolian red clay sediments of the Chinese Loess Plateau. Journal of Geophysical Research 106: DOI: 10.1029/2000JB900445.

Diniz, E.H., Jayo, M., Pozzebon, M., Lavoie, F. and Foguel, F.H. (2014) ICT Helping to scale up microfinance: The case of a successful bank-MFI partnership in Brazil. JGIM, 22.1 (2014): 34-50. DOI: 10.4018/jgim.2014010103.

Diodato, V. P., \& Gellatly, P. (2013). Dictionary of bibliometrics. Routledge.

Dovers, S. (2005) Environment and Sustainability Policy: Creation, Implementation, Evaluation. Stephen Dovers (ed.). The Federation Press, Leichardt, ISBN 1-86287540-5.

Duflo, E., Banerjee, A., Glennerster, R. and Kinnan, C. (2013) The miracle of microfinance? Evidence from a randomized evaluation. NBER Working Paper no. 18950, May 2013, NBER Program.

Dworkin, S.L. and Blankenship, K. (2009) Microfinance and HIV/AIDS prevention: Assessing its promise and limitations. AIDS Behavior, 2009 June; 13(3): 462-9. DOI: 10.1007/s10461-009-9532-3.

Emrouznejad, A., Parker, B. and Tavares, G. (2008) Evaluation of research in efficiency and productivity: A survey and analysis of the first 30 years of scholarly literature in DEA. Journal of Socio-Economics Planning Science, 42(3): 151-157. 
Falagas, M.E., Pitsouni, E.I., Malietzis, G.A. and Pappas, G. (2008). Comparison of PubMed, Scopus, Web of Science, and Google Scholar: Strengths and weaknesses, FASEB Journal, 22, 338-342.

Feigenberg, B., Field, E. \& Pande, R. (2013) The Economic Returns to Social Interaction:

Experimental Evidence from Microfinance, Review of Economic Studies, 80 (4): 1459-1483.

Ferguson, L. (2010). Interrogating 'gender'in development policy and practice: The World Bank, tourism and microenterprise in Honduras. International Feminist Journal of Politics, 12(1), 3-24.

Fomba, E. M. (2008). Reinforcing experiential learning with training culture as an innovative governance strategy in informal microfinance institutions. International Journal of Technology Management, 45(1-2), 141-155.

Fraley, C., \& Raftery, A. E. (1998). How many clusters? Which clustering method? Answers via model-based cluster analysis. The computer journal, 41(8), 578-588.

Garfield, E. (1975) Citation analysis studies. Science, 189 (4200): 397, Letter, no. 248.

Garfield, E., Malin, M. and Small, H. (1978) Citation Data as Science Indicators (Chapter 8). Toward a Metric of Science: The Advent of Science Indicators (Elkana Y., Lederberg J., Merton R.K., Thackray A., Zuckerman H., eds.). New York: Wiley: 179-207, 1978.

Giné, X. and Karlan, D.S. (2014) Group versus individual liability: Short and long term evidence from Philippine microcredit lending groups. Journal of Development Economics, vol. 107(C): 65-83.

Gladwin, T. N., Kennelly, J. J., \& Krause, T.-S. (1995). Shifting paradigms for sustainable development: Implications for management theory and research. Academy of Management Review, 20(4), 874-907.

Glänzel, W., \& Moed, H. F. (2002). Journal impact measures in bibliometric research. Scientometrics, 53(2), 171-193.

Global Reporting Initiative (GRI), G4 Sustainability Reporting Guidelines, https://www.globalreporting.org/resourcelibrary/GRIG4-Part1-ReportingPrinciples-and-Standard-Disclosures.pdf

González, A. (2010) Analyzing microcredit interest rates a review of the methodology 
proposed by Mohammed Yunus. MIX Data Brief, 4, February.

Granados, M.L., Hlupi, V., Coakes, E. and Mohamed, S. (2011) Social enterprise and social entrepreneurship research and theory: A bibliometric analysis from 1991 to 2010. Social Enterprise Journal, Vol. 7, no. 3, 2011: 198-218. DOI: 10.1108/17508611111182368.

Gutiérrez-Nieto, B. and Serrano-Cinca, C. (2009) Factors influencing funder loyalty to microfinance institutions. Nonprofit and Voluntary Sector Quarterly, April 2010, vol. 39, no. 2: 302-320. DOI: 10.1177/0899764009333691.

Hackston, D. and Milne, M. (1996) Some determinants of social and environmental disclosures in New Zealand companies. Accounting, Auditing \& Accountability Journal, Vol. 9, Issue: 1: 77-108. DOI: 10.1108/09513579610109987.

Hall, J., Collins, L., Israel, E., \& Wenner, M. (2008). The missing bottom line: Microfinance and the environment. Philadelphia: GreenMicrofinance-LLC.

Harper, M. (2012) Microfinance interest rates and client returns. Journal of Agrarian Change, vol. 12, Issue 4: 564-574. DOI: 10.1111/j.1471-0366.2012.00374.x.

Hartarska, V. \& Mersland, R. (2009) Which Governance Mechanisms Promote Efficiency in Reaching Poor Clients? Evidence from Rated Microfinance Institutions, European Financial Management, Vol. 18, No. 2, 218-239.

Hartarska, V. \& Mersland, R. (2012) Which governance mechanisms promote efficiency in reaching poor clients? Evidence from rated microfinance institutions. European Financial Management, vol. 18, Issue 2: 218-239.

Hartarska, V. (2009) The impact of outside control in microfinance. Managerial Finance, vol. 35 , no. $12,975-989$.

Hartarska, V. and Nadolnyak, D. (2007) Do regulated microfinance institutions achieve better sustainability and outreach? Cross-country evidence. Applied Economics, vol. 39(10): 1207-1222.

Haughton, G. (1999) Environmental justice and the sustainable cit,. Journal of Planning Education and Research, 8(3): 233-243.

Heino, H. (2006) Use of borrowed start-up capital and micro enterprises in Mexico: Existence of liquidity constraints. Portuguese Economic Journal, May 2006, vol. 5, Issue 1: 1-30. 
Helms, B. (2006) Access for all. Building Inclusive Financial Systems. CGAP. The International Bank for Reconstruction and Development/The World Bank. DOI: 10.1596/978-0-8213-6360-7

Hermes, N. (2014) Does microfinance affect income inequality? Applied Economics, vol. 46(9): 1021-1034.

Hermes, N. and Lensink, R. (2007) Impact of microfinance: a critical survey. Economic and Political Weekly, February, 10, 2007. www.epw.org.in.

Hermes, N., Lensink, R. and Meesters, A. (2011) Outreach and Efficiency of Microfinance Institutions. World Development, Volume 39, Issue 6, June 2011: 938948. DOI: 10.1016/j.worlddev.2009.10.018.

Holsti, O. (1969) Content analysis for the social sciences and humanities. Reading, MA: Addision-Wesley.

Hudon, M. (2009) Should Access to Credit be a Right?, Journal of Business Ethics, 84:17-28.

Hulme, D. (2000) Impact assessment methodologies for microfinance: Theory, experience and better practice", World Development. Vol. 28, no. 1, 79-98, 2000.

Janda, K. and Svárovská, B. (2010) Investing into microfinance. Journal of Business Economics and Management, 01/2010; 11(3). DOI: 10.3846/jbem.2010.24.

Janda, K. and Svárovská, B. (2013) Performance of microfinance investment vehicles. Journal of Economics, Issue 01, 2013: 47-66.

Jensen, E.J., Pfister, L., Ackerman, A.S., Tabazadeh, A. and Toon, O.B. (2001) A conceptual model of the dehydration of air due to freeze-drying by optically thin, laminar cirrus rising slowly across the tropical tropopause. Journal of Geophysical Research, 106: 17237-17252. DOI: 10.1029/2000JD900649.

Joakim, E. P., \& Wismer, S. K. (2015). Livelihood recovery after disaster. Development in Practice, 25(3), 401-418.

Johnson, S. (2005) Gender relations, empowerment and microcredit: Moving on from a lost decade. The European Journal of Development Research, Volume 17, Issue 2: 224-248. DOI: 10.1080/09578810500130831.

Kabeer, N. (2005) Is Microfinance a 'Magic Bullet' for Women's Empowerment? Analysis of Findings from South Asia, Economic and Political Weekly, Vol. 40, No. 
44/45, pp. 4709-4718.

Kar, A.K. and Swain, R.B (2014) Interest rates and financial performance of microfinance institutions: Recent global evidence European. Journal of Development Research, 26: 87-106. DOI: 10.1057/ejdr.2013.33.

Kaspereit, T. and Lopatta, K. (2016) The value relevance of SAM's corporate sustainability ranking and GRI sustainability reporting in the European stock markets. Business Ethics: A European Review, 25: 1-24. doi: 10.1111/beer.12079

Kaufman, L., \& Rousseeuw, P. J. (2009). Finding groups in data: an introduction to cluster analysis (Vol. 344). John Wiley \& Sons.

Khawari, A. (2004) Microfinance: Does it hold its promises? A survey of recent literature. HWWA. Discussion Paper no. 276. DOI: http://dx.doi.org/10.2139/ssrn.556213.

Kiiza, B. and Pederson, G. (2012) ICT-based market information and adoption of agricultural seed technologies: Insights from Uganda. Telecommunications Policy, Volume 36, Issue 4, May 2012: 253-259.

Kim, S.M. (2014) The impacts of gender differences in social capital on microenterprise business start-up. Affilia, November 2014, 29: 404-417. DOI: $10.1177 / 0886109913519789$.

Kolk, A. (2008) Sustainability, accountability and corporate governance: Exploring multinationals' reporting practices. Business Strategy and the Environment, Volume 17, Issue 1: 1-15. DOI: 10.1002/bse.511.

Kono, H. and Takahashi, K. (2010) Microfinance revolution: Its effects, innovations and challenges. The Developing Economies, Special Issue: The role of microfinance in rural finance: evidence from India and Indonesia, Volume 48, Issue 1: 15-73, March 2010. DOI: 10.1111/j.1746-1049.2010.00098.x.

Krippendorff, K.H. (2013) Content Analysis: An Introduction to Its Methodology (3th ed.). London, SAGE Publications. ISBN: 9781412983150

Landmann, A. \& Frölich, M. (2015) Can health-insurance help prevent child labor? An impact evaluation from Pakistan, Journal of Health Economics, 39, 51-59.

Larrú, J.M. (2008) Random impact evaluations and microcredits. Revista de Economía Mundial 19, 2008: 33-62.

Ledgerwood, J. (1999) Microfinance handbook. The World Bank. Washington D.C. 
Liket, K.C., Rey-García, M. and Maas, K.E. (2014) Why aren’t evaluations working and what to do about it a framework for negotiating meaningful evaluation in nonprofits. American Journal of Evaluation, 2014. DOI: 10.1177/1098214013517736.

Lozano, R. (2012). Towards better embedding sustainability into companies' systems: an analysis of voluntary corporate initiatives. Journal of Cleaner Production, 25, 14-26.

Maclean, K (2012) Banking on women's labour: Responsibility, risk and control in village banking in Bolivia. Journal of International Development, Special Issue: Poverty, Financial Inclusion and Livelihood Strategies, Volume 24, Issue Supplement S1: S100-S111. DOI: 10.1002/jid.1744.

Mallick, D. (2012) Microfinance and moneylender interest rate: Evidence from Bangladesh. World Development, Volume 40, Issue 6, June 2012: 1181-1189.

Mersland, R. (2009) The Cost of Ownership in Microfinance Organizations. World Development, Volume 37, Issue 2, February 2009: 469-478.

Mersland, R. and Strøm, Ø (2009) Performance and governance in microfinance institutions. Journal of Banking \& Finance, Volume 33, Issue 4, April 2009: 662669.

Mersland, R., D'Espallier, B. and Supphellen, M. (2013) The Effects of Religion on Development Efforts: Evidence from the Microfinance Industry and a Research Agenda. World Development, Volume 41, January 2013: 145-156.

Mersland, R., Strøm, Ø. (2009) Performance and governance in microfinance institutions, Journal of Banking \& Finance, 33: 662-669.

Milana, C. and Ashta, A. (2012) Developing microfinance: A survey of the literature. Strategic Change, Special Issue: Microfinance, Volume 21, Issue 7-8: 299-330. DOI: 10.1002/jsc. 1911.

Mills, S. (2007) The Kuyasa Fund: Housing microcredit in South Africa. Environment and Urbanization, October 2007, vol. 19, no. 2: 457-469. DOI: 10.1177/0956247807082825.

Moneva, J.M., Rivera-Lirio, J.M. and Muñoz-Torres, M.J. (2007) The corporate stakeholder commitment and social and financial performance. Industrial Management \& Data Systems, 107 (1): 84-102.

Moran, D. D., Wackernagela, M., Kitzesa, J. A., Goldfingera, S. H. and Boutaud, A. 
(2008) Measuring sustainable development: Nation by nation, Ecological Economics 64(3): 470-474.

Morduch, J. (1999) The Microfinance Promise. Journal of Economic Literature, 37(4): 1569-1614. DOI: 10.1257/jel.37.4.1569.

Mori, N, Golesorkhi, S., Randøy, T. and Hermes, N. (2015) Board Composition and Outreach Performance of Microfinance Institutions: Evidence from East Africa, Strat. Change 24: 99-113.

Moro Visconti, R. (2012) A Survey on Microfinance for Developing Countries: A Social Responsible Investment Opportunity. DOI:10.2139/ssrn.1284472.

Mosley, P. (2001) Microfinance and poverty in Bolivia. The Journal of Development Studies, 37, 101-132.

Muñoz-Torres, M. J., Rivera-Lirio, J. \& Moneva-Abadía J. M. (2008) Evaluating sustainability in organisations with a fuzzy logic approach, Industrial Management \& Data Systems, Vol. 108 Iss: 6, pp.829-841.

Newman, A., Schwarz, S. and Borgia, D. (2014) How does microfinance enhance entrepreneurial outcomes in emerging economies? The mediating mechanisms of psychological and social capital. International Small Business Journal, March 2014, vol. 32, no. 2: 158-179. DOI: 10.1177/0266242613485611.

Nishat, A. (2004) Poverty and Environment: role of microfinance. IUCN-The World Conservation Union, Bangladesh.

OECD (2014): Development co-operation report 2014. http://goo.gl/aGTwTs. [05/04/2015]

Okubo, Y. (1997) Bibliometric Indicators and Analysis of Research Systems: Methods and Examples. OECD Science, Technology and Industry Working Papers, no. 1997/01, OECD Publishing, Paris. DOI: http://dx.doi.org/10.1787/208277770603.

Parvin, G. A., \& Shaw, R. (2013). Microfinance institutions and a coastal community's disaster risk reduction, response, and recovery process: a case study of Hatiya, Bangladesh. Disasters, 37(1), 165-184.

Périlleux, A., Hudon, M. and Bloy, E. (2012) Surplus distribution in microfinance differences among cooperative, nonprofit, and shareholder forms of ownership. Nonprofit and Voluntary Sector Quarterly, June 2012, vol. 41, no. 3: 386-404. DOI: 


\section{$10.1177 / 0899764011406287$.}

Plümper, T. and Radaelli, C. (2004) Publish or perish? Publications and citations of Italian political scientists in international political science journals, 1990-2002. Journal of European Public Policy, Volume 11, Issue 6: 1112-1127. DOI: $10.1080 / 1350176042000298138$.

Price, D. (1965) Networks of scientific papers. Science, 149(3686): 510-515.

Pritchard, A. (1969) Statistical bibliography or bibliometrics, Journal of Documentation, Vol. 25, no. 4: 348-9.

Pronyk, P.M., Kim, J.C., Abramsky, T., Phetla, G., Hargreaves, J.R., Morison, L.A., Watts, C., Busza, J. and Porter, J.D. (2008) A combined microfinance and training intervention can reduce HIV risk behaviour in young female participants. AIDS, 2008 Aug 20, 22(13): 1659-65. DOI: 10.1097/QAD.0b013e328307a04.

Rafols, I. and Meyer, M. (2010) Diversity and network coherence as indicators of interdisciplinarity: case studies in bionanoscience. Scientometrics, Volume 82, Issue 2: 263-287.

Rahdari, A. H., \& Rostamy, A. A. A. (2015). Designing a general set of sustainability indicators at the corporate level. Journal of Cleaner Production, 108, 757-771.

Rahman, A. (1999) Micro-credit initiatives for equitable and sustainable development: Who pays? World Development, Vol. 27, Issue 1, pp 67-82.

Rikken, B., van Busschbach, J., le Cessie, S., Manten, W., Spermon, T., Grobbee, R. and Wit, J.M. (1995) Impaired social status of growth hormone deficient adults as compared to controls with short or normal stature. Clin Endocrinol (Oxf), 43: 205211.

Robinson, M. (2001) The Microfinance revolution. The World Bank \& Open Society Institution. Washington D.C.

Rock, R., Otero, M. \& Saltzman, S. (1998) Principles and Practices of Microfinance Governance, ACCION International, August 1998.

Rohatynskyj, M. (2011) Development Discourse and Selling Soap in Madhya Pradesh, India. Human Organization, Spring 2011, Vol. 70, no. 1: 63-73. DOI: http://dx.doi.org/10.17730/humo.70.1.m424616118180254

Roman, R.M., Haybor, S. and Agle, B.R. (1999) The relationship between social and 
financial performance, Business and Society, Vol. 38, no. 1: 109-25.

Rosenberg, R. (2009) Measuring Results of Microfinance Institutions. Minimum Indicators That Donors and Investors Should Track. A Technical Guide, CGAP, June 2009.

Sahu, G. B. (2015). How Effective is a Self-Help Group Led Microfinance Programme in Empowering Women? Evidence from Rural India. Journal of Asian and African Studies, 50(5), 542-558.

Saint-Supéry Ceano-Vivas, M., Muñoz-Torres, M. J., \& Rivera Lirio, J. M. (2014). Revisiting the Relationship between Sustainable Development and Social Cohesion.

Saj, P. (2013) Charity performance reporting: comparing board and executive roles, Qualitative Research in Accounting \& Management, Vol. 10 Iss: 3/4, pp.347-368.

Scholtens, B. (2008) A note on the interaction between corporate social responsibility and financial performance, Ecological Economics, Volume 68, Issues 1-2: 46-55.

Schreiner, M., \& Woller, G. (2003). Microenterprise development programs in the United States and in the developing world. World development, 31(9), 1567-1580.

Schuster, C.E. (2014) The social unit of debt: Gender and creditworthiness in Paraguayan microfinance. American Ethnologist, Volume 41, Issue 3: 563-578, August 2014. DOI: 10.1111/amet.12095

Seale, C., Ziebland, S., \& Charteris-Black, J. (2006) Gender, cancer experience and internet use: a comparative keyword analysis of interviews and online cancer support groups, Social science \& medicine, 62(10), 2577-2590.

Serrano-Cinca, C. \& Gutiérrez-Nieto, B. (2014) Microfinance, the long tail and mission drift. International Business Review, Volume 23, Issue 1, February 2014: 181-194.

Serrano-Cinca, C., Gutiérrez-Nieto, B., Reyes, N. (2016) A social and environmental approach to microfinance credit scoring, Journal of Cleaner Production, 112, 35043513.

Seuring, S. \& Müller, M. (2008) From a literature review to a conceptual framework for sustainable supply chain management, Journal of Cleaner Production, 16: 16991710 .

Sharma, G.L. and Puri, H. (2013) Effectiveness of Microfinance: A Literature Survey. International Journal of Advanced Research in Business Management and 
Administration, Volume1, Issue 1: 105-114.

Singh R. K., Murty, H.R., Gupta, S.K. \& Dikshit, A.K. (2012) An overview of sustainability assessment methodologies, Ecological Indicators, Vol. 15, Issue 1, pp 281-299.

Smets, P. (2006). Small is beautiful, but big is often the practice: Housing microfinance in discussion. Habitat International, 30(3), 595-613.

Smith, S.C. (2012) The scope of NGOs and Development Programme Design: Application to Problems of Multidimensional Poverty. Public Administration and Development, Special Issue: Governance and eradication of poverty: new perspectives for multidisciplinary analysis, Volume 32, Issue 4-5: pages 357-370, October-December 2012. DOI: 10.1002/pad.1635.

Srnec K., Svitaková J., Výborná M. and Burian P. (2011): Microfinance as a suitable instrument of European and Czech development cooperation. Agric. Econ. - Czech, 57 (2011): 529-533

Ssewamala, F.M., Karimli, L., Chang-Keun, H. and Ismayilova L. (2010) Social capital, savings, and educational performance of orphaned adolescents in Sub-Saharan Africa. Children and Youth Services Review, 2010; 32(12): 1704-1710. DOI: 10.1016/j.childyouth.2010.07.013.

Starik, M. \& Kanashiro, P. (2013) Toward a Theory of Sustainability Management: Uncovering and Integrating the Nearly Obvious, Organization \& Environment, $\mathrm{XX}(\mathrm{X}): 1-24$.

Stevens, K. \& Morris, J. (2001) Struggling towards sustainability: considering grassroots development. Sustainable Development 9(3): 149-164.

Takahashi, K., Higashikata, T. and Tsukada, K. (2010) The short-term poverty impact of small-scale, collateral-free microcredit in Indonesia: A matching estimator approach. The Developing Economies, Special Issue: The role of microfinance in rural finance: Evidence from India and Indonesia, Vol. 48, Issue 1: 128-155, March 2010. DOI: 10.1111/j.1746-1049.2010.00101.x.

Thorndike, R. L. (1953). Who belongs in the family?. Psychometrika, 18(4), 267-276.

Tilbury, D. (1995) Environmental education for sustainability: Defining the new focus of environmental education in the 1990s'. Environmental Education Research, 1, 2: 
$195-212$.

Tower, A. (2016). Income-generating Project Initiation in Churches: A Guide for Mission Workers. Transformation: An International Journal of Holistic Mission Studies, 33(2), 124-135.

Tsai, K.S. (2004) Imperfect Substitutes: The Local Political Economy of Informal Finance and Microfinance in Rural China and India. World Development, Vol. 32, no. 9: 1487-1507, 2004. DOI: 10.1016/j.worlddev.2004.06.001.

van Elteren, A. (2007) Environmental and Social Risk Management and Added Value at MFIs and MFI Funds - The FMO approach, The Hague: Netherlands Development Finance Company (FMO).

van Marrewijk, M. (2003) Concepts and definitions of CSR and corporate sustainability: Between agency and communion. Journal of Business Ethics, Volume 44, Issue 2-3: 95-105.

van Raan, A. (2005) Measuring Science. Handbook of Quantitative Science and Technology Research 2005: 19-50. DOI: 10.1007/1-4020-2755-9_2.

van Rooyen, C., Stewart, R. and de Wet, T. (2012) The Impact of Microfinance in SubSaharan Africa: A Systematic Review of the Evidence. World Development, vol. 40(11): 2249-2262.

Vanroose A. and D'Espallier, B. (2013) Do microfinance institutions accomplish their mission? Evidence from the relationship between traditional financial sector development and microfinance institutions: outreach and performance. Applied Economics, Volume 45, Issue 15, 2013: 1965-1982. DOI: 10.1080/00036846.2011.641932.

Vos, S.J., Xiong, C., Visser, P.J., Jasielec, M.S., Hassenstab, J., Grant, E.A., Cairns, N.J., Morris, J.C., Holtzman, D.M. and Fagan, A.M. (2013) Preclinical Alzheimer's disease and its outcome: A longitudinal cohort study. Lancet Neurol. 2013 Oct; 12(10): 957-65.

Warnecke, T. (2014) The 'individualist entrepreneur' vs. socially sustainable development: Can microfinance build community? Journal of Economic Issues, 2014, vol. 48, issue 2: 377-386.

Waweru, N. and Spraakman, (2012) The use of performance measures: case studies from 
Microfinance Literature: A Sustainability Level Perspective Survey

the microfinance sector in Kenya, Qualitative Research in Accounting \& Management, Vol. 9, No. 1, pp. 44-65.

Weber, H. (2004) The 'new economy' and social risk: Banking on the poor? Review of International Political Economy, 11 (2): 356-386. ISSN 0969-2290 http://dx.doi.org/10.1080/09692290420001672859.

Weber, H. (2014) Global politics of microfinancing poverty in Asia: The case of Bangladesh unpacked. Asian Studies Review, 38 4: 544-563. DOI: 10.1080/10357823.2014.963508.

Yunus, M. (1999). Banker to the Poor (First ed.). United States: PublicAffairs. ISBN 1891620-11-8.

Zhang, Y. and Wildemuth, B.M. (2009) Qualitative analysis of content. In B. Wildemuth (Ed.), Applications of Social Research Methods to Questions in Information and Library Science (pp. 308-319). Westport, CT: Libraries Unlimited.

Zhou, G., Su, J., J. and Zhang, M. (2005) Exploring various knowledge in relation extraction. ACL-05: 427-434.

\section{Abbreviations}

EESG Economic, Environment, Social, Governance

GRI Global Reporting Initiative

SLR Systematic Literature Review
MFI Micro-Finance Institution

TTR Type Token Ratio 
A continuación se presenta la versión postprint del artículo con referencia:

García-Pérez, I., \& Muñoz-Torres, M. (2015). Evaluación integral de las entidades microfinancieras desde la perspectiva de sostenibilidad. Harvard Deusto Business Research, 4(1), 17-33

DOI: https://doi.org/10.3926/hdbr.71 



\title{
Resumen
}

Tras una revisión de la literatura sobre el impacto de las microfinanzas desde la perspectiva de la sostenibilidad, a través de la interrelación de las dimensiones financiera, ambiental, social y de gobernanza (FASG) y un análisis de su desempeño en la promoción de la inclusión financiera y la erradicación de la pobreza, presentamos una evaluación integral e inclusiva de las entidades microfinancieras que permita obtener una mejor comprensión de la situación actual de estas instituciones.

Los resultados permiten detectar aspectos que necesitan ser revisados en el sector como es el caso del sobreendeudamiento, el impacto ambiental de la financiación o el objetivo de reducción de pobreza, para garantizar la sostenibilidad de estas instituciones y permitir una adecuada gestión de los programas de financiación en todas sus dimensiones.

Palabras clave Institución microfinanciera, sostenibilidad, análisis FASG, impacto social, pobreza.

\begin{abstract}
Following a review of the literature on the impact of microfinance from the sustainability perspective, through the interrelation of economic, environmental, social and governance dimensions (ESG), and an analysis of its performance in promoting financial inclusion and poverty eradication, we present a comprehensive and inclusive assessment of microfinance institutions that allows obtaining a better understanding of the current status of these institutions.
\end{abstract}

The results detect aspects as over-indebtedness, environmental impact of funding or poverty reduction target as issues that need to be reviewed to ensure the sustainability of these institutions and enable proper management of funding programs in all its dimensions.

Key words Microfinance institution, sustainability, ESG analysis, social impact, poverty. 


\section{Introducción}

Entre la gran diversidad de agentes que proveen servicios de intermediación en el sector financiero, se encuentran las denominadas Instituciones Microfinancieras (IMF). Desde una perspectiva inclusiva, la literatura define las IMF como aquellas que proveen productos y servicios financieros a clientes de bajos ingresos (MIX Market, 2010), con el objetivo de reducir la exclusión financiera e incrementar el bienestar de millones de personas pobres en todo el mundo (Lacalle, Rico, Márquez, \& Durán, 2006), siendo consideradas herramientas de desarrollo (Ledgerwood, 1998).

Inmersos en un contexto global y bajo el prisma de la sostenibilidad, el análisis de desempeño de la actividad de las organizaciones no puede realizarse únicamente desde su ejercicio económico, sino que es preciso medir su impacto bajo una mayor amplitud de criterios. El análisis a través de la interrelación de las dimensiones financiera, ambiental, social y de gobernanza (FASG), ha aumentado significativamente su presencia en la evaluación de procesos para responder a la gestión de la compañías ante inversores individuales e institucionales, accionistas y gobiernos desde un punto de vista sostenible (Manescu, 2011; Balagué, \& Badal, 2012; Galbreath, 2013), así como en la creación de una estrategia competitiva, y la reducción de riesgos (Kocmanová \& Němeček, 2009; Galbreath, 2013;). Aunque no existe consenso sobre el impacto de la gestión sostenible sobre los resultados de los programas de microfinanzas, existe literatura reciente que muestra que una adecuada gestión bajo criterios FASG sugiere una repercusión positiva en los resultados económicos y en el desempeño global de las organizaciones (Kocmanová \& Němeček, 2009; Hřebiček, Soukopova, Štencl, \& Trenz, 2011; Peiró, Segarra, Mondéjar, \& Vargas, 2013).

Dado el alto grado de vulnerabilidad del colectivo al que se dirige el sector, en parte, como consecuencia del elevado riesgo de exclusión financiera (Kempson \& Whyley, 1999; Panigyrakis, Theodoriris, \& Veloutsou, 2002; Amaeshi, Ezeoha, \& Nwafor, 2007), y considerado el entorno de sostenibilidad en el que opera, se ha generado un interés creciente en relación con su desempeño que se refleja en la literatura desde una perspectiva económica (Morduch, 1999; Gutiérrez-Nieto, Serrano-Cinca, \& Mar, 2005; 
Kaboski \& Townsend, 2009; González, 2010), social (Von Pischke, 1998; Hulme, 2000; Mosley, 2001; Coleman, 2002), ambiental (van Elteren, 2007; Hall, Collins, Israel \& Wenner, 2008; Allet, 2011) y de gobernanza (Rock, Otero, \& Saltzman, 1998; Barrès \& Nagarajan, 2001; Mersland \& Storm, 2009). Sin embargo, hasta donde llega nuestro conocimiento, hay una notable falta de estudios que evalúen a las IMF de manera integrada.

Por lo tanto, el principal objetivo de este estudio será reflejar el comportamiento actual de las IMF presentando una visión global en términos de desempeño sostenible, considerando por tanto las dimensiones financiera, ambiental, social y de gobernanza.

Si bien los estudios previos se basan, en general, en estudios de casos o programas concretos de microfinanciación, establecer cuáles están siendo las estrategias y situaciones organizacionales actuales a nivel mundial, es un punto de partida imprescindible para sentar las bases de futuras investigaciones. El presente estudio refleja la evaluación de desempeño de las IMF en un contexto de sostenibilidad considerando las dimensiones FASG de manera conjunta, ampliando el rango de conocimiento con respecto a las evaluaciones habituales y que permitirá profundizar en la relación entre las diferentes dimensiones, valorar su impacto y la detectar de un modo más preciso aquellas áreas necesitadas de una revisión en la gestión de los programas de financiación.

La estructura de trabajo es la siguiente: tras la introducción, en la sección 2 se presenta una revisión de la literatura sobre el impacto de las microfinanzas desde las perspectivas financiera, ambiental, social y de gobernanza (FASG) y un análisis de su desempeño en la promoción de la inclusión financiera y la erradicación de la pobreza. En la sección 3, se define la metodología y se presentan las bases de datos utilizadas, para, en la sección 4, desarrollar una discusión de los resultados y finalmente exponer las principales conclusiones. 


\section{Estado del arte}

Uno de los aspectos destacables en el análisis del desempeño financiero de las IMF es que entraña mayor dificultad para estas instituciones que para sus pares "tradicionales" debido a su vertiente marcadamente social. Así, en ocasiones la rentabilidad financiera queda supeditada a la labor que ejercen y su impacto en la sociedad (Schreiner, 1999; van Maanen, 2004) y son consideradas efectivas desde el momento en que proveen un servicio a la sociedad, asumiendo, en ocasiones, que los costes de los programas puedan ser superiores a sus beneficios (Armendáriz de Aghion \& Morduch, 2005; Kaboski \& Townsend, 2009).

El que las IMF operen bajo condiciones y objetivos diferentes a los de la banca tradicional no significa, que no deba contemplarse su desempeño y sostenibilidad financiera (Gutiérrez-Nieto et al., 2005). Este análisis va a constituir uno de los pilares que sustenten la garantía de pervivencia de las funciones de las IMF. Por tanto, su evaluación conlleva un trabajo técnico y examen más amplio, ya que el impacto de los elementos estrictamente financieros no puede ser disgregado de otros factores.

Tradicionalmente, en el análisis de desempeño de las entidades microfinancieras ha prevalecido la evaluación de los aspectos sociales y económicos aunque actualmente, algunas IMF y expertos están comenzando a incluir el medioambiente como tercer objetivo (Allet \& Hudon, 2013; Hall et al., 2008; van Elteren, 2007). En general, el conjunto de indicadores que mejor da respuesta a los principales problemas ambientales señalados en la literatura podríamos circunscribirlo a indicadores relacionados con el uso de los recursos, la medición de la contaminación, y de aquellas actividades que entrañan riesgo para la salud y que generalmente, se desarrollan al margen de cualquier sistema de regulación (Nishat, 2004; van Elteren, 2007; Hall et al., 2008; Allet, 2011).

Respecto al análisis del impacto social y la pobreza, la mayoría de autores coinciden en la dificultad que entraña valorar estos resultados, en parte por la falta de datos adecuados para la medida del desempeño social (Baker, 2000), y la compleja estructura de grupos de interés de las IMF (Morduch, 1999; Hulme, 2000; Armendáriz de Aghion \& 
Morduch, 2005).

En este estudio esta valoración se abordará mediante variables que revelen la calidad de las prácticas efectuadas para los distintos colectivos y siguiendo la evolución del nivel de pobreza de los clientes registrado por la IMF.

Como revela el trabajo de Hartarska (2005), existe la evidencia de una relación entre los mecanismos de gobierno corporativo y el desempeño de las IMF. Este análisis conlleva la consideración del sector en términos de su doble misión, valorando su sistema de propiedad, su responsabilidad fiduciaria y la evaluación de riesgos (Rock et al., 1998), así como las funciones y la composición de la Junta y la dirección (Hartaska, 2005; Council of Microfinance Equity Funds, 2012), y la transparencia como vehículo de mejora de sus prácticas (Barrès \& Nagarajan, 2001; Waterfield, 2009).

Dada la heterogeneidad de programas, estatus de las instituciones, público objetivo o países de actuación, las conclusiones obtenidas en los diferentes trabajos varían considerablemente. Por lo tanto, hay que señalar que no existen unas conclusiones generales y unánimes en lo referente al desempeño de las IMF en su ámbito financiero, ambiental, social y de gobernanza.

Tras esta revisión presentamos como primer resultado una aproximación a la construcción de un sistema de indicadores de evaluación de resultados, realizada de manera holística (cuadro 1) y en un contexto de sostenibilidad, que articule las dimensiones FASG y que permita con ello detectar cuáles son aquellas áreas necesitadas de revisión en la gestión de los programas de financiación, valorar su impacto y determinar si existe desvío de la misión.

La selección de estas variables se basa, tanto en la revisión de la literatura anteriormente presentada como en la translación hacia el sector de normas, estándares y diferentes metodologías de rating social, así como de otros modelos de sistemas de información, ciñéndose a aquellos conjuntos de factores disponibles que expliquen el estado de la cuestión en este particular y que se revelan como mejores indicadores de sostenibilidad. 
Cuadro 1. Variables analizadas según categoría y referencia

\begin{tabular}{|c|c|}
\hline Variables por perspectiva & Referencia \\
\hline $\begin{array}{l}\text { Perspectiva financiera } \\
\mathrm{N}^{\circ} \text { prestatarios, } \mathrm{n}^{\circ} \text { de prestatarios por empleado y por } \\
\text { institución, importe medio de préstamo y en relación } \\
\text { al PIB per cápita, coste medio por prestatario, } \\
\text { porcentaje de mujeres prestatarias, no depositantes, } \\
\text { importe medio de depósitos, ROA, ROE, } \\
\text { autosuficiencia operativa, sostenibilidad financiera, } \\
\text { riesgo medio de la cartera. }\end{array}$ & $\begin{array}{l}\text { ACCION, González (2010), } \\
\text { Gutiérrez-Nieto et al. (2005), Hulme } \\
\& \text { Mosley (1996), MicroRate, } \\
\text { Morduch (1999), Planet Rating } \\
\text { (analytical framework) }\end{array}$ \\
\hline $\begin{array}{l}\text { Perspectiva ambiental } \\
\text { Dimensión interna: reciclaje papel, minimización del } \\
\text { uso de electricidad convencional, reciclaje agua, } \\
\text { minimización del uso de combustibles } \\
\text { convencionales, política ambiental propia escrita para } \\
\text { la actividad de la entidad. } \\
\text { Dimensión externa: concienciación a clientes, } \\
\text { identificación de empresas con riesgos ambientales, } \\
\text { identificación de carteras con riesgos ambientales } \\
\text { formación a clientes, inclusión cláusulas en contratos, } \\
\text { créditos ligados a energías alternativas, política } \\
\text { ambiental escrita para la actividad del cliente. }\end{array}$ & $\begin{array}{l}\text { Allet (2011), Allet \& Hudon (2013), } \\
\text { Global Reporting Initiative, } \\
\text { Principios del Ecuador, van Elteren, } \\
\text { (2007), De la Cuesta et al. (2006) }\end{array}$ \\
\hline Perspectiva social & \\
\hline $\begin{array}{l}\text { Productos y servicios asociados: productos } \\
\text { financieros, yield on gross loan portfolio, servicios no } \\
\text { financieros. } \\
\text { Clientes: público objetivo, alcance de género, } \\
\text { prevención del sobreendeudamiento, porcentaje de la } \\
\text { cartera con retraso en los pagos de más de } 30 \text { y } 90 \text { días. } \\
\text { Empleados: formación, transparencia, igualdad, } \\
\text { protección en el trabajo, participación empleados, } \\
\text { cupo de mujeres en plantilla y cargos, políticas de } \\
\text { conciliación, evaluación, sistema de incentivos. } \\
\text { Comunidad: generación de nuevos puestos de trabajo, } \\
\text { apoyo para el desarrollo económico o social, } \\
\text { concesión de crédito a empresas con valores sociales } \\
\text { negativos, liderazgo de las mujeres, apoyo en caso de } \\
\text { emergencias, habla el idioma local, eliminación } \\
\text { trabajo infantil y trabajos forzosos, política escrita de } \\
\text { responsabilidad social frente a la comunidad. } \\
\text { Impacto sobre la pobreza: Índice de medida de la } \\
\text { pobreza, evolución del nivel de pobreza (bajo la línea } \\
\text { de pobreza, menos de uno o dos dólares al día). }\end{array}$ & $\begin{array}{l}\text { Cheston \& Khun (2002), Ditcher } \\
\text { (2006), Goetz y Sen Gupta (1996), } \\
\text { Gómez (2006), GRI, Hashemi et al. } \\
\text { (1996), Hulme \& Mosley (1996), } \\
\text { MFTransparency, MicroFinanza } \\
\text { Rating, MicroRate, Minh-Phoung \& } \\
\text { Wahhaj (2012), Morduch (1999), } \\
\text { Planet Rating (Social Performance } \\
\text { Rating), Principios del Ecuador, } \\
\text { Schicks (2010), Social Performance } \\
\text { Task Force, UN Gobal Compact }\end{array}$ \\
\hline $\begin{array}{l}\text { Perspectiva de gobernanza } \\
\text { Tamaño de las Juntas Directivas, número de mujeres } \\
\text { en la Junta miembros integrantes en la Junta, registro } \\
\text { documental, código escrito de ética empresarial, } \\
\text { asuntos sociales en el plan de negocio, comité de } \\
\text { desempeño social, transparencia. }\end{array}$ & $\begin{array}{l}\text { Barrès \& Nagarajan (2001), Council } \\
\text { of Microfinance Equity Funds } \\
\text { (2012), GRI, Mersland \& Storm } \\
\text { (2009), MicroFinanza Rating, Planet } \\
\text { Rating (analytical framework), Rock } \\
\text { et al. (1998) }\end{array}$ \\
\hline
\end{tabular}




\section{Metodología}

Para el análisis de la situación del sector a nivel mundial, utilizaremos una metodología cuantitativa, basada en fuentes secundarias, a partir de bases de datos sobre la realidad social, con datos contables y de desempeño de IMF. Los datos relativos al área económica corresponden al año fiscal 2013. Los datos acerca del desempeño social, ambiental y de gobernanza corresponden al último año disponible con información pública y gratuita $^{1}$ (2009), obtenida a través de la plataforma MIX Market.

La información contenida estas bases de datos es de carácter voluntario y para asegurar su calidad están sometidas a procedimientos internos de auditoría.

La muestra se compone de $324^{2}$ IMF pertenecientes a cinco regiones predefinidas: África, EAP (East Asia and the Philippines), ECA (Europe and Central Asia), LAC (Latin America and the Caribbean), MENA (Middle East and North Africa) y South Asia.

El tamaño muestral corresponde a una población total de 1457 individuos $^{3}$ en 2009, para un nivel de confianza del $95 \%$, error muestral del $2 \%$ y proporción del $5 \%$ que maximice nuestro tamaño muestral y que atienden a las cuestiones relativas al desempeño social, ambiental y de gobernanza.

En el caso de los resultados económicos correspondientes se ha trabajado con los datos de la población total de IMF con clientes activos para el año 2013.

Para la codificación de la información relativa a cada una de las dimensiones se ha

\footnotetext{
${ }^{1}$ La última actualización disponible corresponde al año 2011 y en el que tras una revisión del cuestionario original, MIX Market ha eliminado variables que en mi estudio son determinantes como son asuntos relativos a las actuaciones frente a la comunidad, la actuación ambiental interna y la evolución del nivel de pobreza de los clientes.

${ }^{2}$ Los datos desagregados por indicador y área geográfica se encuentran disponibles bajo petición a los autores.

${ }^{3}$ Número total de instituciones microfinancieras en 2009 con clientes activos. Fuente: MIX Market
} 
Evaluación integral de las entidades microfinancieras

desde la perspectiva de sostenibilidad

Capítulo II

utilizado la técnica de análisis univariante de datos, cuya aplicación es habitual en los estudios donde el objetivo es el de evaluar el estado del sector a nivel general o con un enfoque económico, social o ambiental (Morduch, 1999; Gertler, Levine, \& Moretti, 2009; Christopher, 2010; Kimani, Ettarh, Kyobutungi, Mberu, \& Muindi, 2012; Pop \& Bresfelean, 2011).

Si bien cualquier modelo simplifica la realidad, el análisis descriptivo de estos indicadores en un marco FASG nos proporciona una caracterización a grandes rasgos del sector de las microfinanzas; permitiendo que las conclusiones obtenidas a partir de este análisis nos ayuden a avanzar un paso más en el conocimiento del estado actual del sector a nivel agregado y proporcionando un conjunto de variables extraídas de la literatura, para analizar y comparar experiencias del sector.

\section{Discusión de resultados}

\subsection{Perspectiva financiera}

Atendiendo al resultado de nuestro estudio sobre las variables recogidas en el cuadro 1, estas IMF están dando crédito a más de 58 millones de personas a nivel global, con una media de 116.000 clientes por institución y de 134 clientes por empleado.

El tamaño medio del préstamo es de 775 dólares, y este en relación al PIB per cápita es del 36,5\%, con gran dispersión de los datos por región (86,5\% en África, frente al 9\% en el sur de Asia). Cada préstamo genera unos costes de 160 dólares por prestatario, siendo mayor esta cifra cuando se trata de la financiación de pequeños negocios.

Los datos indican que en un $65 \%$ de los casos los créditos son concedidos a mujeres. Sin embargo, si analizamos por región se observa que si bien en la mayoría de áreas la titularidad del crédito es aproximada al 50\% entre hombres y mujeres, en la caso del sur de Asia, la cifra es del 99,95\% de prestatarias.

El alcance es similar cuando se trata de depósitos, en cuyo caso la cifra de depositantes es de 51 millones de personas, con un importe medio de 496 dólares por 
depósito.

A pesar de la importancia que se concede a los productos de ahorro como pieza clave en el desarrollo del sector, se observa una falta de relación entre número de depósitos y depositantes, su autosuficiencia y rentabilidad. Es decir, un mayor número de ahorradores y depósitos, no implica una mayor rentabilidad ni sostenibilidad de la institución, como ya adelantaron Gutiérrez-Goira y Goitisolo (2011) en su estudio empírico.

El cuadro 2 presenta la autosuficiencia operativa, ROE y ROA de las IMF, por región, en relación al número de depósitos y depositantes para el año 2013.

Los valores de autosuficiencia operativa, describen la relación entre los ingresos financieros y la suma de gastos financieros, amortización de préstamos y costes operativos. Es decir, la autosuficiencia operativa se produce cuando una IMF cubre todos sus costes operativos a través de sus ingresos financieros (Lacalle, et al., 2006).

Cuadro 2. Relación entre autosuficiencia operativa, rentabilidad, número de depositantes y cuentas de depósito para el año 2013

\begin{tabular}{|l|l|l|l|l|l|}
\hline Región & $\begin{array}{l}\text { Autosuficiencia } \\
\text { Operativa }(\boldsymbol{\%})\end{array}$ & $\begin{array}{l}\text { ROA } \\
(\boldsymbol{\%})\end{array}$ & $\begin{array}{l}\text { ROE } \\
(\boldsymbol{\%})\end{array}$ & Depositantes & $\mathbf{N}^{\mathbf{0}}$ cuentas \\
\hline África & 105,46 & 0,65 & 2,22 & 15.164 .381 & 15.364 .642 \\
\hline LAC & 110,67 & 1,65 & 7,92 & 22.477 .486 & 27.156 .715 \\
\hline South Asia & 115,94 & 1,98 & 11,26 & 5.834 .549 & 6.402 .628 \\
\hline MENA & 116,18 & 3,34 & 10,02 & 18.660 & 21.846 \\
\hline ECA & 118,63 & 3,02 & 12,25 & 4.468 .889 & 5.935 .136 \\
\hline EAP & 125,88 & 3,96 & 15,72 & 3.300 .026 & 3.638 .515 \\
\hline
\end{tabular}

Las regiones de África y Latinoamérica a pesar de poseer el mayor volumen de depósitos y depositantes, son las que presentan un peor desempeño en términos de rentabilidad y autosuficiencia operativa. Y en el caso contrario, el este de Asia con un $18 \%$ menos depósitos y ahorradores que las dos áreas anteriores, figura con el mejor 
desempeño y rentabilidad del conjunto de regiones.

Atendiendo al desempeño financiero del sector en función de si la institución posee o no ánimo de lucro, se observa que en el periodo comprendido entre 2007 y 2013, en media, las entidades que no tienen ánimo de lucro, no son menos rentables que las que buscan beneficios.

Es importante aclarar que las cifras obtenidas de ROA y ROE en el caso de las IMF deben ser tomadas con cautela, ya que estos indicadores son más adecuados para las instituciones que no reciben subsidios (Rosenberg, 2009) y que si bien ambos indicadores son un reflejo de rentabilidad, éstos deben ser ajustados para reflejar el impacto de las subvenciones.

Un indicador ajustado de uso común es la sostenibilidad financiera (FSS), considerada como la capacidad de mantener y ampliar la oferta de servicios financieros generando los ingresos netos necesarios para cubrir sus costes (Rosenberg, 2009), que no ha sufrido variaciones remarcables entre 2007 y 2013. Situándose en torno al $60 \%$ el porcentaje de IMF sostenibles financieramente.

\subsection{Perspectiva ambiental}

La valoración de esta categoría, se va a llevar a cabo desde una óptica doble. Por un lado, las actuaciones directas de la IMF, su dimensión interna, en la que se considerarán factores asociados a su eficiencia energética y política ambiental. Y la dimensión externa, que en el caso de las IMF, cobra especial relevancia, en la medida en la que a través del crédito promueve determinadas actividades y sectores.

En relación a su dimensión interna, actuaciones propias, y siguiendo el símil con el sector financiero (Muñoz-Torres, Fernández-Izquierdo, \& Escrig, 2013) para la definición de sus indicadores, el reciclaje de papel (62\%), la minimización del uso de electricidad convencional (51\%) y el reciclaje de agua y minimización del uso de combustibles (ambas con un $31 \%$ ) son las prácticas más extendidas para el caso de las IMF analizadas. 
El cuadro 3, muestra en detalle cuál es el comportamiento de las IMF a nivel medioambiental en relación a sus actuaciones directas por región.

Cuadro 3. Comportamiento de las IMF a nivel medioambiental en relación a sus actuaciones directas por región (porcentaje)

\begin{tabular}{|l|c|c|c|c|c|c|c|}
\hline $\begin{array}{l}\text { Acciones medioambientales } \\
\text { (dimensión interna) }\end{array}$ & África & EAP & ECA & LAC & MENA & $\begin{array}{c}\text { South } \\
\text { Asia }\end{array}$ & Total \\
\hline Recicla papel & 45,00 & 63,89 & 42,42 & 71,62 & 61,11 & 63,89 & 61,63 \\
\hline $\begin{array}{l}\text { Minimiza el uso de } \\
\text { electricidad convencional }\end{array}$ & 40,00 & 50,00 & 34,85 & 59,48 & 33,33 & 63,89 & 51,23 \\
\hline Recicla agua & 25,00 & 33,33 & 18,18 & 39,19 & 16,67 & 30,56 & 21,17 \\
\hline $\begin{array}{l}\text { Minimiza el uso de } \\
\text { combustibles convencionales }\end{array}$ & 20,00 & 5,56 & 12,12 & 28,38 & 5,56 & 8,33 & 18,52 \\
\hline $\begin{array}{l}\text { La organización posee una } \\
\text { Política Ambiental propia } \\
\text { escrita }\end{array}$ & 5,00 & 27,78 & 15,15 & 13,51 & 27,78 & 16,67 & 16,05 \\
\hline
\end{tabular}

En relación a su dimensión medioambiental externa (cuadro 4), actuaciones frente a terceros, el $44 \%$ de las IMF crea conciencia a sus clientes sobre impactos ambientales, el $32 \%$ identifica las empresas en cartera con riesgos ambientales y el $26 \%$ forma a sus clientes respecto a mejoras ambientales.

Sin embargo, en cuanto a actuaciones respecto a sus clientes, son relativamente pocas las instituciones las que las llevan a cabo. Así, solo un $15 \%$ de los créditos incluyen cláusulas específicas para mitigar riesgos sociales y ambientales y un 12\% ofrece créditos ligados a energías alternativas. 
Cuadro 4. Comportamiento de las IMF a nivel medioambiental en relación a sus actuaciones indirectas por región (porcentaje)

\begin{tabular}{|l|l|l|l|l|l|l|l|}
\hline $\begin{array}{l}\text { Acciones medioambientales } \\
\text { (dimensión externa) }\end{array}$ & África & EAP & ECA & LAC & MENA & $\begin{array}{l}\text { South } \\
\text { Asia }\end{array}$ & Total \\
\hline $\begin{array}{l}\text { Crea conciencia a sus clientes } \\
\text { sobre impactos ambientales }\end{array}$ & 60,00 & 50,00 & 36,36 & 42,57 & 38,89 & 47,22 & 43,52 \\
\hline $\begin{array}{l}\text { Identifica empresas con } \\
\text { riesgos ambientales }\end{array}$ & 40,00 & 33,33 & 48,48 & 25,68 & 16,67 & 27,78 & 31,79 \\
\hline $\begin{array}{l}\text { Forma a sus clientes respecto } \\
\text { a mejoras ambientales }\end{array}$ & 35,00 & 27,78 & 16,67 & 27,03 & 16,67 & 36,11 & 25,93 \\
\hline $\begin{array}{l}\text { Existe una Política Ambiental } \\
\text { escrita para los clientes a los } \\
\text { que financia }\end{array}$ & 5,00 & 27,78 & 28,79 & 16,22 & 33,33 & 19,44 & 20,68 \\
\hline $\begin{array}{l}\text { Se incluyen cláusulas } \\
\text { específicas en los contratos } \\
\text { de préstamo para mitigar los } \\
\text { riesgos } \\
\text { específicos ambientales }\end{array}$ & 25,00 & 13,89 & 24,24 & 13,51 & 5,56 & 8,33 & 15,43 \\
\hline $\begin{array}{l}\text { Ofrece líneas de crédito } \\
\text { ligadas a energías alternativas }\end{array}$ & 15,00 & 16,67 & 12,12 & 11,49 & 16,67 & 2,78 & 11,73 \\
\hline
\end{tabular}

A nivel formal, casi la totalidad de las organizaciones carece de política ambiental propia y un escaso 21\% de IMF posee una Política Ambiental escrita para los clientes o microempresas a las que financia.

Estudiando cada una de las diferentes actuaciones medioambientales, tanto en su dimensión interna como externa, en todas ellas se cumple que el tamaño medio de las instituciones comprometidas es superior al de las no comprometidas. Del mismo modo, el tamaño medio de las instituciones comprometidas es superior a la media general.

Asimismo, la excelencia en gestión medioambiental se da en instituciones de mayor tamaño. Si consideramos en cuántas de las once actuaciones anteriormente contempladas participan cada una de las entidades, se observa las entidades que ejecutan cuatro o más objetivos, tienen un tamaño superior a la media.

En relación a la edad, las entidades entre 8 y 15 años, son las que en conjunto llevan a cabo un mayor número de actuaciones relacionadas con el medioambiente. 
En general, las IMF con estatus de banco efectúan un mayor número de acciones medioambientales que el resto de figuras jurídicas.

El cuadro 5, muestra las 'notas' medias por estatus legal. Estas notas se han calculado sumando el número de actuaciones en las que la institución declara participar.

Cuadro 5. Comparativa de nota media por tipo de institución

\begin{tabular}{|l|c|c|}
\hline Estatus legal & Puntuación media & Diferencia respecto a la media \\
\hline Banco & 4,93 & 1,65 \\
\hline ONG & 3,33 & 0,05 \\
\hline Cooperativa/Unión de Crédito & 3,12 & $-0,16$ \\
\hline IFNB & 3,11 & $-0,17$ \\
\hline Banco rural & 1,33 & $-1,95$ \\
\hline Media general & 3,28 & \\
\hline
\end{tabular}

Pese a que los datos reflejan que las IMF calificadas como banco tienen un mejor compartimiento que la media, lo más revelador es el escaso compromiso generalizado en cuestiones medioambientales en el sector.

Atendiendo a los resultados del estudio del Allet y Hudon (2013), las IMF de mayor tamaño, tienen un mejor desempeño en políticas ambientales, huella ecológica y evaluación de riesgos medioambientales y las instituciones más maduras tienen un mejor comportamiento ambiental. Conclusiones que coinciden con el comportamiento de nuestra muestra.

En su estudio, reflejan que en cuanto al estatus, aquellas registradas como banco tienen mejores prácticas para la evaluación de riesgo y políticas medioambientales, mientras que las calificadas como ONG o más activas en áreas rurales, desarrollan mejor los servicios no financieros asociados al medioambiente, sin embargo en la muestra analizada aquellas IMF calificadas como banco reflejan un mejor desempeño en todas las actuaciones medioambientales.

No obstante lo anterior, es importante señalar que para las características de la 
población anteriormente citadas como son tamaño, edad y estatus legal y su relación con el cumplimiento de acciones medioambientales, no se ha encontrado una relación de correlación determinante.

\subsection{Perspectiva social}

Siguiendo con la estructura del análisis propuesto, el impacto social se va a analizar desde la perspectiva de los principales grupos de interés que conformarían el mapa de stakeholders, siguiendo los mecanismos de evaluación de modelos como el GRI o el Pacto Global de Naciones Unidas, tal y como se recoge en el cuadro 1, añadiendo el análisis del producto desde la perspectiva del cliente como punto de partida.

\section{Productos y servicios asociados}

Los principales productos y servicios financieros que ofrecen estas instituciones se agrupan en tres categorías: Crédito, Ahorro y Seguros.

En el caso de créditos, se materializan esencialmente en microcréditos para financiar microempresas (98\%), préstamos ligados a agricultura (63\%) y préstamos para PYMES (56\%). Estas cifras son interesantes, en la medida en que la literatura empírica evidencia casos concretos en los que existe una relación positiva y significativa entre la concesión de esta financiación y el desempeño de la PYMES en términos de cuota de mercado, eficiencia productiva y competitividad (Bolnick \& Nelson, 1990; Franks, 2000; Mosley, 2001; Christopher, 2010).

No se dispone de las cifras relativas a las tasas aplicadas a los microcréditos, pero dada la relevancia de este dato, se ha tomado el yield on gross loan portfolio como aproximación.

La tendencia general entre los años 2007 y 2013 ha sido estable, con una media de $28,7 \%$, con diferencias pequeñas entre áreas, a excepción de la región de África, cuya tendencia es ascendente con un notable incremento en el último año en el que alcanza un 
36,4\% de media de rendimiento bruto de la cartera de préstamos. En general, organizaciones y académicos atribuyen unos precios más elevados comparados con los de otras instituciones financieras a los costes administrativos y de personal, la elevada prima de riesgo y en ocasiones, al traspaso al cliente de la falta de eficiencia en el control de costes de la propia organización (Waterfield, 2009; Prior \& Argandoña, 2009; González, 2010; MFTransparency, 2013).

Los productos de ahorro, son gestionados por menos de la mitad de las IMF estudiadas (40\%). Materializándose en depósitos voluntarios, depósitos a plazo fijo y depósitos obligatorios utilizados como garantía en efectivo.

La oferta de seguros es la de menor presencia en nuestra muestra de organizaciones (21\%). Los más comercializados son los seguros de vida asociados al titular del crédito (41\%) y los seguros de vida en general y de salud (32\% y $11 \%$ respectivamente). La importancia de esta tercera categoría se pone de manifiesto como complemento a los tradicionales microcréditos y como mecanismo de cobertura en estructuras deficientes (Mishra, 1994; Nourse, 2001; Kimani et al., 2012).

Entre los servicios no financieros destacan los servicios de la alfabetización financiera (44\%), formación empresarial para mujeres (40\%), desarrollo empresarial que incluyen asesoramiento, consultoría y servicios de marketing (37\%) y servicios médicos básicos $(21 \%)$.

La literatura empírica pone de manifiesto que las IMF necesitan focalizarse más en sus clientes para ofrecer un conjunto de productos financieros que se adapten a las necesidades específicas de este colectivo (Cohen, 2000; Woller, 2004; Armendáriz de Aghion \& Morduch, 2005).

\section{Clientes}

El perfil del cliente tipo para las IMF analizadas es mujer (85\%), con bajos ingresos (82\%) y que habita en el área rural (35\%).

En relación al alcance de género, tanto en el caso de préstamos individuales como 
solidarios para el año 2013, la cifra de prestatarias es del 65\%. Como se indicó anteriormente, esta cifra varía mucho por región, por lo que es interesante precisar que si bien en la mayoría de áreas la titularidad del crédito es aproximada al 50\% entre hombres y mujeres, en la caso del sur de Asia, la cifra es del 99,95\% de prestatarias.

El interés principal de este dato radica en la medida en la que esta financiación puede afectar al empoderamiento o fortalecimiento de las competencias de la mujer, la confianza en sí mismas, las relaciones familiares y con respecto a la violencia de género, al estatus en el hogar y en la comunidad, pero sobre todo, en la toma de decisiones (Cheston \& Khun, 2002; Gómez, 2006). En este último aspecto, si bien la mayoría de académicos acuerda que el efecto es positivo, hay estudios que sugieren que no es tan determinante. Los estudios de Goetz y Sen Gupta (1996) y Hashemi, Schuler y Riley (1996), señalan que los casos en los que las mujeres son las que han tomado la decisión sobre la contratación y el futuro uso del dinero se sitúa entre el $37 \%$ y el $63 \%$. Recordemos, que en el caso de las IMF estudiadas, la titularidad del ahorro es eminentemente masculina mientras que el endeudamiento, con la responsabilidad que conlleva, es asumido en su mayoría por las mujeres.

Además, si atendemos al resultado del estudio llevado a cabo por Minh-Phoung y Wahhaj (2012), sugiere que una intervención que requiere la cooperación de ambos cónyuges y se asegura de que ninguno de los cónyuges se vea perjudicado, puede tener más éxito en el logro de los impactos sociales que las intervenciones que se centran solo esferas autónomas de las mujeres.

Con anterioridad se mencionaban las importantes consecuencias que se podían derivar de un sobreendeudamiento en un colectivo ya de por sí vulnerable. En relación al riesgo de impago, durante el periodo 2007-2009 se produjo un deterioro significativo de la cartera de clientes del sector microfinanciero. En media, los retrasos en los pagos de más 30 días eran cercanos al 3\% y del 1,5\% para 90 días en el año 2007, duplicando estas cifras en 2009. Entre los años 2009 y 2013, se observa un control del grado de sobreendeudamiento, alcanzando en 2013 cifras muy similares a las de 2007. 
Esta mejora en la calidad de las carteras, coincide con una reducción del número de IMF en valor absoluto, siendo mayor el descenso de instituciones no reguladas frente a reguladas. También se observa una diversificación de productos, con gran incremento en la cifra de depósitos, así como un aumento progresivo de IMF con mayor alcance (más de 30.000 prestatarios por institución). Factores relacionados con la saturación del mercado, su nivel de formalidad, diversificación de productos o alcance son aspectos que CGAP (2011), en su informe acerca del sobreendeudamiento en el microcrédito, señalaba podrían afectar positivamente a su reducción.

En cuanto al comportamiento por región, este no ha variado a lo largo de los años. África permanece como la región con mayor riesgo de cartera, con un porcentaje de retraso en los pagos dos veces superior al de las regiones de Asia.

De la muestra de IMF, el 65\% de las instituciones declara formar a su plantilla para la prevención del sobreendeudamiento, cifra que no parece muy elevada dada la importancia de sus efectos nocivos. Por otra parte, el $86 \%$ señala que lleva a cabo procesos de evaluación de la asequibilidad del préstamo ${ }^{4}$.

\section{Empleados}

Se pone de manifiesto la actitud de estas instituciones respecto a este grupo a través de la formación impartida, transparencia, composición de la plantilla y políticas aplicadas.

Más de la mitad de los altos directivos, mandos intermedios y agentes de crédito, reciben formación en asuntos relacionados con la responsabilidad social. El objetivo de esta formación es fundamentalmente la orientación a la misión (72\%), cómo dar respuesta a las necesidades de los clientes (71\%), la comunicación de los precios (68\%) y en menor medida, medida de la pobreza $(30 \%)$.

Las políticas más tenidas en cuenta por las instituciones son la transparencia en sueldos, seguros y pensiones (96\%), la igualdad de remuneración y políticas

\footnotetext{
${ }^{4}$ Lamentablemente la información de la que se dispone indica si existe o no el proceso y no su desarrollo o su grado de cumplimiento.
} 
antidiscriminación (93\%) y la protección en el trabajo, que incluye seguridad y normas anti-acoso (85\%).

El porcentaje de mujeres en plantilla es del 38\%; y en lo referente a políticas de conciliación, la que de forma general es más practicada (90\%) es la de permisos de maternidad o paternidad, la adaptación del horario de trabajo en función de condicionantes familiares (31\%) y las políticas de apoyo a la movilidad (27\%).

En cuanto a incentivos, un $63 \%$ de las IMFs premia a sus empleados por la consecución de determinados objetivos, fundamentalmente en relación a la calidad de la cartera, la capacidad de captación de clientes y la fidelización.

\section{Comunidad}

El impacto de la actividad de las IMF transciende más allá del propio receptor del préstamo a través de la financiación de empresas de nueva creación y generación de puestos de empleo formales. Las instituciones evaluadas, declaran haber generado más de un millón y medio de puestos de trabajo a nivel global.

Además, entre las acciones que promueven, destacan con un 65\% el apoyo a la comunidad local para el desarrollo económico o social, evitar la concesión de crédito a empresas con valores sociales negativos, denegando la financiación a actividades que puedan perjudicar o atentar directa o indirectamente contra determinados colectivos o entornos (62\%), el apoyo al liderazgo de las mujeres (56\%) y apoyo a la comunidad local en caso de emergencias (39,5\%). Aunque en menor medida, el 25\% contribuye a la eliminación del trabajo infantil y el 15\% a la eliminación de los trabajos forzosos.

En el cuadro 6, se desglosan por región todas las acciones relacionadas con la comunidad contempladas en la muestra y el porcentaje de instituciones que contribuyen a cada una de ellas. 
Cuadro 6. Porcentaje de IMF que contemplan en su actividad diversas acciones relacionadas con la comunidad por región

\begin{tabular}{|l|l|l|l|l|l|l|l|}
\hline $\begin{array}{l}\text { Acciones frente a la } \\
\text { Comunidad }\end{array}$ & África & EAP & ECA & LAC & MENA & $\begin{array}{l}\text { South } \\
\text { Asia }\end{array}$ & Total \\
\hline $\begin{array}{l}\text { Apoya a la comunidad } \\
\text { local para el desarrollo } \\
\text { económico o social }\end{array}$ & 75,00 & 75,00 & 53,03 & 16,92 & 66,67 & 58,33 & 65,43 \\
\hline $\begin{array}{l}\text { Evita entregar crédito a } \\
\text { empresas con valores } \\
\text { sociales negativos }\end{array}$ & 75,00 & 72,22 & 53,03 & 56,76 & 72,22 & 80,56 & 62,35 \\
\hline $\begin{array}{l}\text { Apoya el liderazgo de las } \\
\text { mujeres }\end{array}$ & 50,00 & 55,56 & 45,45 & 57,43 & 61,11 & 75,00 & 56,48 \\
\hline $\begin{array}{l}\text { Apoya a la comunidad } \\
\text { local en caso de } \\
\text { emergencias }\end{array}$ & 65,00 & 61,11 & 19,70 & 38,51 & 38,89 & 44,44 & 39,51 \\
\hline $\begin{array}{l}\text { Empleados que hablan el } \\
\text { idioma local }\end{array}$ & 45,00 & 44,44 & 27,27 & 25,00 & 33,33 & 61,11 & 33,33 \\
\hline $\begin{array}{l}\text { Promueve condiciones de } \\
\text { trabajo razonables }\end{array}$ & 35,00 & 50,00 & 33,33 & 19,59 & 55,56 & 47,22 & 31,79 \\
\hline $\begin{array}{l}\text { Contribuye a la } \\
\text { eliminación del trabajo } \\
\text { infantil }\end{array}$ & 40,00 & 33,33 & 19,70 & 18,92 & 33,33 & 41,67 & 25,31 \\
\hline $\begin{array}{l}\text { Contribuye a la } \\
\text { eliminación de trabajos } \\
\text { forzosos }\end{array}$ & 15,00 & 13,89 & 15,15 & 10,81 & 16,67 & 30,56 & 14,81 \\
\hline
\end{tabular}

A nivel formal, menos de un $30 \%$ de las instituciones cuenta con una política escrita de responsabilidad social frente a la comunidad.

\section{$\underline{\text { Impacto sobre la pobreza }}$}

Para determinar la evolución del nivel de pobreza, las IMF analizadas que realizan un seguimiento en este sentido de sus clientes, indican cuántos clientes entraron viviendo por debajo de la línea de la pobreza y cuántos clientes, después de tres o cinco años, viven por encima de esta línea (cuadro 7).

También se cuantifica cuántos prestatarios accedieron al programa viviendo con menos de un dólar al día y cuántos de estos, después de tres o cinco años, viven con más de un dólar al día. Del mismo modo se realiza para aquellos que ingresaron viviendo con 


\section{Evaluación integral de las entidades microfinancieras} desde la perspectiva de sostenibilidad

menos de dos dólares y tras tres o cinco años, superan esta cifra.

En el caso de las instituciones presentes en la base de datos de MIX Market para el año fiscal 2009, hay que contemplar que el $58 \%$ no mide la pobreza de sus clientes al inicio del programa y sólo la mitad lo hace después de tres o cinco años en él ${ }^{5}$.

Cuadro 7. Seguimiento del nivel de pobreza a nivel global (porcentaje)

\begin{tabular}{lccc}
\hline & Acceso & 3 años & $\mathbf{5}$ años \\
\hline Por debajo de la línea de pobreza & $34,83 \%$ & & \\
\hline Superan la línea de pobreza & & $42,55 \%$ & $47,02 \%$ \\
\hline Menos de 1\$/día & $34,18 \%$ & & \\
\hline Superan 1\$/día & & $9,40 \%$ & $11,95 \%$ \\
\hline Menos de 2\$/día & $48,97 \%$ & & \\
\hline Superan 2\$/día & & $22,97 \%$ & $18,32 \%$ \\
\hline
\end{tabular}

Para aquellas IMF que sí realizan un seguimiento del nivel de pobreza, los resultados obtenidos indican que el $35 \%$ de clientes acceden viviendo por debajo de la línea de la pobreza, y a los cinco años de estar en el programa, casi la mitad de estos pasan a vivir por encima de esta línea.

Sin embargo, en el caso de clientes que entran viviendo con menos de un dólar al día (34\%), solo un $12 \%$ de estos pasan a vivir con más de un dólar al día a los cinco años. Resultados similares se obtienen en el caso de clientes que acceden a los programas viviendo con dos dólares al día (49\%), en esta categoría, tras cinco años, el 18\% supera los dos dólares.

Lamentablemente la base de datos de MIX Market provee el porcentaje de clientes para un nivel de pobreza determinado, así como el porcentaje de aquellos que mejoran su posición, pero no especifica los casos en lo que la posición de pobreza ha empeorado tras su ingreso en el programa.

Si bien estos datos parecen corroborar lo que indican otros estudios que consideran

\footnotetext{
${ }^{5}$ Tasa promedio de respuesta del 31\% para la pregunta: '¿existe medida de los niveles de pobreza tras permanecer en el programa tres o cinco años?'
} 
que el mayor efecto de las microfinanzas se da en los niveles más bajos de pobreza, hay que considerar que la tasa de respuesta en relación al porcentaje de clientes que mejora su posición es muy reducida ${ }^{6}$, por lo que es importante señalar la débil consistencia de las conclusiones que se puedan obtener.

\subsection{Perspectiva de gobernanza}

Para conocer el estado del Gobierno Corporativo de las IMF a nivel mundial, se han utilizado las variables que se recogen en el cuadro 1, de entre las provistas por MIX Market para el año 2009 y que fundamentalmente hacen referencia a su dimensión interna.

El modelo de Junta Directiva más habitual en el caso de las IMF analizadas, consta de ocho miembros, seis hombres y dos mujeres, y cuentan la participación de al menos alguno de sus principales grupos de interés, como son clientes, representantes gubernamentales, empresas independientes o representantes de la comunidad.

A nivel documental, la actuación es deficiente, ya que solo un $15 \%$ de las instituciones realiza actas de estas Juntas y casi la mitad de IMF prescinde de un código escrito de ética empresarial.

En relación al plan de negocio, el 82\% de IMF contempla asuntos de desempeño social, sin embargo, solo un 22\% tiene un Comité para vigilar su ejecución.

El tratamiento de la transparencia, tiene cifras dispares, ya que cuando hace referencia a los beneficios para los empleados (salarios, seguros y pensiones), el $96 \%$ de las IMF estudiadas, publica esta información. Mientras que cuando se trata de transparencia de precios, solo un 5\% revela estos datos a la organización MFTransparency Inititative.

\footnotetext{
${ }^{6}$ Tasa promedio de respuesta del 6\% a la cuestión: 'Porcentaje de clientes que mejora su posición tras tres o cinco años en el programa'.
} 


\section{Conclusiones}

El presente estudio evalúa descriptivamente el estado del sector microfinanciero a nivel global en relación a su desempeño en un contexto de sostenibilidad, articulando las perspectivas financiera, ambiental, social y de gobernanza en su cometido de paliar la exclusión financiera y aliviar la pobreza.

En relación al desempeño financiero, tradicionalmente, la medida de rentabilidad no ha sido uno de los objetivos primordiales en el sector financiero dado que su función social y como instrumento de desarrollo eran cruciales. En términos globales, la rentabilidad de las organizaciones no se relaciona con un mayor número de productos de ahorro y en media, las instituciones sin ánimo de lucro no son menos rentables que aquellas que buscan beneficios.

Sin embargo, los indicadores habituales ROA y ROE en microfinanzas, presentan ciertas peculiaridades que dificultan su comparación directa con la banca convencional. Deben ser tomados con cautela ya que no incluyen el impacto de las subvenciones y precisan ser ajustados. En este sentido, la sostenibilidad financiera, como indicador ajustado, apunta que más de la mitad de las IMF son sostenibles financieramente.

Dada la vocación con la que nacen las microfinanzas y con su clara orientación hacia la sociedad, parece que sus actuaciones se rigen, en mayor o menor medida bajo ciertos criterios de responsabilidad social. En general, tanto para gobierno corporativo, empleados y comunidad el grado de compromiso es alto.

En relación a clientes, como consecuencia de una evolución del sector en estos últimos años y su mejora en la calidad de las carteras, con una disminución del riesgo de impago hace que se haya incrementado la protección de este colectivo frente al sobreendeudamiento y las nocivas consecuencias que este provoca, tanto para la propia supervivencia de la entidad como para las condiciones de vida del prestatario.

En el área de medioambiente se observa que las mejores actuaciones se realizan por instituciones maduras, de mayor tamaño y con status de banco, sin embargo, existe una 
necesidad de reforzar sus actuaciones, sobretodo en su dimensión externa, en la consideración del destino de la financiación y la promoción de actividades económicas sostenibles.

El impacto social del sector es sólido en cuanto a que provee productos y servicios a colectivos con riesgo de exclusión financiera. Sin embargo, la baja tasa de respuesta en las variables relacionadas con la evolución del nivel de pobreza hace que no se puedan obtener conclusiones suficientemente consistentes, por lo que, asumiendo las dificultades que conlleva medir el impacto social, sería conveniente profundizar en cómo se están gestionando estos programas o si se existe desvío de la misión, ya que solo a través de la evaluación y seguimiento de estos programas se podrá mejorar su desempeño, modificando o eliminando aquellos de elevados costes y promoviendo aquellos cuyo presupuesto y esfuerzo estén bien focalizados.

Una de las limitaciones que presenta el estudio es que algunas de las variables contempladas indican si una determinada acción se realiza o no, pero no se indican los procedimientos establecidos, recursos involucrados o la periodicidad de realización. Para futuras investigaciones sería deseable un mayor grado de profundización en el protocolo y cumplimiento de determinadas prácticas.

Una cuestión que resulta compleja de analizar, sobre todo debido a la falta de información homogénea intra-entidad, son las interacciones entre los aspectos FASG. Aun sí se detectan cuestiones que pueden dar lugar a profundizar en futuras investigaciones. Tal es el caso del mejor desempeño financiero en áreas geográficas donde el grueso de los prestatarios son mujeres, lo que sugiere una interacción positiva entre género y sostenibilidad financiera de los programas.

\section{Referencias bibliográficas}

Allet, M. (2011): "Measuring the environmental performance of microfinance: a new tool", Université Libre de Bruxelles.

Allet, M., \& Hudon, M. (2013): “Green Microfinance. Characteristics of MFIs 
involved in environmental management". CEB Working Paper n. 13/005.

Amaeshi, K., Ezeoha, A., Adi, C., \& Nwafor, M. (2007): "Financial Exclusion and Strategic Corporate Social Responsibility: A missing link in sustainable finance discourse?” Research Paper Series, n. 49-2007.

Armendáriz de Aghion, B., \& Morduch, J. (2005). The Economics of Microfinance, The MIT Press, Cambridge.

Baker, J. (2000). Evaluación del impacto de los proyectos de desarrollo en la pobreza. Manual para profesionales, World Bank, Washington D.C.

Barrès, I., \& Nagarajan, G. (2001): “Transparency Initiatives”, The Microbanking Bulletin Focus on Transparency. Issue n. 7.

Balagué, J., Naviné, F. (2012): “Sistema de indicadores para la gestión sostenible de un destino turístico: aplicación a la Costa Brava", Harvard Deusto Business Research, Vol. 1, N. 2. 132-146.

Bateman, M. (2010). Why Doesn't Microfinance Work? The Destructive Rise of Local Neoliberalism, Zed Books, London.

Bolnick, B., \& Nelson, E. (1990): "Evaluating the Economic Impact of a Special Credit Programme: KIK/KMKP in Indonesia", The Journal of Development Studies, 26, 299-312.

CGAP (2011): “Over-Indebtedness in Microcredit". XIV Inter-American Forum on Microenterprise (Foromic). Costa Rica, October, 2011.

Cohen, M. (2000): "Making microfinance more client-led", Journal of Intl Development, 14, 335-350.

Coleman, B. (2002): "Microfinance in northeast Thailand: Who benefits and how much?", en Armendáriz de Aghion, B., \& Morduch, J. (2005). The Economics of Microfinance, Massachusetts Institute of Technology.

Council of Microfinance Equity Funds (2012): The Practice of Corporate Governance in Shareholder-Owned Microfinance Institutions, Consensus Statement of the Council of Microfinance Equity Funds, en http://www.cmef.com/document.doc?id=1026

Cheston, S., \& Kuhn, L. (2002): Empowering Women through Microfinance, UNIFEM. 
Christopher, I. (2010): Impact of Microfinance on Small and Medium-Sized Enterprises in Nigeria, Conference on Innovation \& Management, 1864-1871.

Ditcher, T. (2006): Hype and Hope: The Worrisome State of the Microcredit Movement, The Microfinance Gateway.

Franks, J. (2000): "Macroeconomic Stabilization and the Microentrepreneur", Journal of Microfinance, Vol. 2, n. 1, 69-91.

Goetz, A. M., \& Sen Gupta, R. (1996): "Who Takes the Credit? Gender, Power, and Control Over Loan Use in Rural Credit Programs in Bangladesh". World Development, Vol. 24, 1, 45-63.

Gómez, C. (2006): "El dilema de los microcréditos en las políticas de desarrollo", Cuadernos Bakeaz, 76, agosto.

González, A. (2010): “Analyzing Microcredit Interest Rates A Review of the Methodology Proposed by Mohammed Yunus”. MIX Data Brief, 4, February.

Galbreath, J. (2013): "ESG in Focus: The Australian Evidence", Journal of Business Ethics, 118, 529-541.

Gertler, P., Levine, D., \& Moretti, E. (2009): “Do microfinance programs help families insuer consumption againt illness?", Health Economics, 18, 257-273.

Gutiérrez-Goiria, J., \& Goitisolo, B. (2011): "Profitability and Social performance of microfinance institutions: empirical evidence of relations between different types of variables", Revista de Economía Mundial, 27, 189-214.

Gutiérrez-Nieto, B. (2000): "Microcréditos y reducción de la pobreza. La experiencia de la AOD española”, http://pendientedemigracion.ucm.es/info/ec/jec7/pdf/com6-5.pdf

Gutiérrez-Nieto, B., Serrano-Cinca, C., \& Mar Molinero, C. (2005): “Microfinance institutions and efficiency", Omega 35 (2007), 131-142.

Hall, J., Collins, L., Israel, E., \& Wenner, M. (2008): The Missing Bottom Line: http://www.microfinancegateway.org/gm/document-1.9.34581/12.pdf

Hřebiček, J., Soukopova,J., Štencl, M., \& Trenz, O. (2011): "Integration of economic, environmental, social and corporate governance performance and reporting in entreprises", Universitatis Agriculturae et Silviculturae, vol. LIX, n 7, 157-166.

Hartarska, V (2005): “Governance and performance of microfinance institutions in 
Central and Eastern Europe and the newly independent states". World Development, vol. 33, Iss. 10, 1627-1643.

Hulme, D. (2000): "Impact Assessment Methodologies for Microfinance: Theory, Experience and Better Practice", World Development. Vol. 28, N. 1, 79-98, 2000.

Hulme, D., \& Mosley, P. (1996): Finance Against Poverty, en Amaeshi, K., Ezeoha, A., Adi, C., \& Nwafor, M. (2007): "Financial Exclusion and Strategic Corporate Social Responsibility: A missing link in sustainable finance discourse?" Research Paper Series, n. 49-2007. Nottingham University Business School.

Kaboski, J., \& Townsend, R. (2009): “The Impacts of Credit on Village Economies", American Economic Journal: Applied Economics, 4(2): 98-133.

Kempson, E., \& Whyley, C. (1999): Kept out or opted out? Understanding and combating financial exclusion, The Policy Press, Bristol.

Kimani, J, Ettarh, R., Kyobutungi, C., Mberu, B., \& Muindi, K. (2012): "Determinants for participation in a public health insurance program among residents of urban slums in Nairobi, Kenya", Health Services Research, 2012, 12-66.

Kocmanová A, \& Němeček, P. (2009): Economic, Environmental and Social Issues and Corporate Governance in Relation to Measurement of Company Performance. Liberec Economic Forum 2009, 177-186.

Lacalle, M.; Rico, S.; Márquez, J. y Durán J. (2006): Glosario básico sobre microfinanzas, Cuaderno Monográfico $\mathrm{n}^{\mathrm{o}}$. 5, Foro Nantik Lum de MicroFinanzas, Madrid.

Ledgerwood, J. (1998): “Microfinance Handbook: An Institutional and Financial Perspective". World Bank Publication.

Manescu, C. (2011): “Stock Returns in Relation to Environmental, Social and Governance Performance: Mispricing or Compensation for Risk?", Sustainable Development, 19, 95-118.

Mersland, R., \& Storm, R. (2009): "Performance and governance in microfinance institutions", Journal of Banking \& Finance, vol. 33, Iss. 4: 662-669.

Minh-Phuong, T., \& Wahhaj, Z. (2012): "Microfinance and gender empowerment", Journal of Development Economics, 99, 1-12.

Mishra, P. (1994): “Crop insurance and crop credit: Impact of the Comprehensive 
Crop Insurance Scheme on co-operative credit in Gujarat", en Brau, J.C. y Woller, G. (2004): "Microfinance: A comprehensive review of the existing literatura", Journal of Entrepreneurial Finance, vol. 9, Iss. 1: 1-27

MIX Market (2010): Glossary of terms. http://www.themix.org/aboutmicrofinance/glossary-terms. [21/04/2015]

Morduch, J. (1999): “The Microfinance Promise”, Journal of Economic Literature. Vol. XXXVII, 1569-1614.

Mosley, P. (2001): "Microfinance and poverty in Bolivia", The Journal of Development Studies, 37, 101-132.

Muñoz-Torres, M. J., Fernández-Izquierdo, M. A., Escrig, E. (2013): "Responsabilidad social corporativa e internacionalización bancaria: el caso de la banca española en Argentina, Brasil y Chile”, Harvard Deusto Business Research. Vol. II. N 2. 143-164.

Nishat, A. (2004): Poverty and Environment: role of microfinance. IUCN-The World Conservation Union, Bangladesh.

Nourse, T. H. (2001): "The missing parts of microfinance: Services for consumption and insurance", SAIS Review, 21, 61-70.

Peiró, A., Segarra, M., Mondéjar, J., \& Vargas, M. (2013): "Influence of the Environmental, Social and Corporate Governance Ratings on the Economic Performance of Companies: An overview”, Intl Journal of Environmental Research, 7 (1), 105-112.

Pop, Z., \& Bresfelean, V. (2011): "Impact of the financial crisis on the Romanian microfinance sector", 13th Intl Conference on Finance and Banking. http://www.opf.slu.cz/kfi/icfb/proc2011/pdf/00b_Contents.pdf

Panigyrakis, G. G., Theodoriris, P. K., \& Veloutsou, C. A. (2002): “All Customers Are Not Treated Equally", en Gutiérrez-Nieto, B. (2008): “Coste del microcrédito versus coste del desempleo", Revista de Economía Mundial, 19, 63-82.

Prior, F., \& Argandoña, A. (2009): "Credit accessibility and corporate social responsibility in financial institutions: the case of microfinance", Business Ethics: A European Review, Vol. 18. N. 4. 349-363

Rock, R., Otero, M., \& Saltzman, S. (1998): "Principles and Practices of Microfinance Governance", ACCION Intl. August 1998. 
Rosenberg, R. (2009): “Measuring Results of Microfinance Institutions. Minimum Indicators That Donors and Investors Should Track. A Technical Guide", CGAP, June 2009.

Schicks, J. (2010): “Microfinance Over-Indebtedness: Understanding its drivers and challenging the common myths", CEB Working Paper, 10/048. Université Libre de Bruxelles - Solvay Brussels School of Economics and Management.

Schreiner, M. (1999): “Aspects of Outreach: A Framework for Discussion of the Social Benefits of Microfinance”, Journal of Intl Development. June 19, 1999.

Hashemi, S, Schuler, R., \& Riley, A. (1996): “Rural Credit Programs and Women's Empowerment in Bangladesh", en Morduch, J. (1999): “The Microfinance Promise", Journal of Economic Literature, Vol. XXXVII, 1569-1614.

Van Elteren, A. (2007): "Environmental and social risk management and added value at MFIs and MFI funds - the FMO approach", The Hague: Netherlands Development Finance Company (FMO).

Van Maanen, G. (2004): "Microcredit sound business or development instrument". Oikocredit.

Von Pischke, J. D. (1998): “Poverty, Human Development and Financial Services”, en Gutiérrez-Nieto, B. (2000): "Microcréditos y reducción de la pobreza. La experiencia de la AOD española".

Waterfield, C. (2009): Why We Need Transparent pricing in microfinance. Microfinance Transparency. 
A continuación se presenta la versión postprint del artículo con referencia:

García-Pérez, I., Muñoz-Torres, M. J., \& Fernández-Izquierdo, M. Á. (2018). Microfinance institutions fostering sustainable development. Sustainable Development

DOI: https://doi.org/10.1002/sd.1731 



\section{Abstract}

The microfinance sector is considered an important contributor to the expansion of formal financial systems. It plays a significant role in sustainable development. Microfinance institutions (MFIs) as key actors in the microfinance sector require an organizational management framework that facilitates sustainable growth. The objective of this study is to define a balanced MFI sustainability approach that considers financial, environmental, social and governance dimensions as equally important. Through a clustering process, this research establishes the relationship between the various sustainability indicators provided by MixMarket, and it determines different MFI sustainability profiles. This research uses the Kruskal-Wallis method to characterize each group based on outreach, financial and risk indicators. The results show that there is no balance between the different sustainability areas, and lead to the conclusion that it is necessary to promote an integrative approach to foster sustainability management practices in the microfinance industry.

Keywords: clustering, FESG dimensions; MFIs; SD; SIs

\section{Introduction}

The financial system affects sustainable development (SD) directly and indirectly (Beck, Demirgüç-Kunt, \& Levine, 2010; Busch, Bauer, \& Orlitzky, 2016; de la CuestaGonzález, Muñoz-Torres, \& Fernández-Izquierdo, 2006; Hu \& Scholtens, 2014). The microfinance sector is considered an important contributor to the strengthening and expansion of the formal financial system (Lopatta, Tchikov, Jaeschke, \& Lodhia, 2017; Vanroose \& D'Espallier, 2013). It has become the world's largest banking market in terms of customers served (Mersland, 2013). MixMarket Global Report 2014 states that 112.5 million clients were provided with access to credit, with a gross loan portfolio of USD87.3 billion and more than 107 billion in global assets. This high-growth industry is also considered, by certain authors, to be one of the major promoters of financial inclusion (Ledgerwood, Earne, \& Nelson, 2013) and poverty alleviation (Robinson, 2001; Yunus, 
1999), as its mission is promoting social welfare and progress (Azad, Masum, Munisamy, \& Sharmin, 2016; Coleman, 2006; Quayes, 2012).

However, most articles have looked at the sustainability of microfinance institutions (MFIs); these refer exclusively to financial sustainability (García-Pérez, Muñoz-Torres, \& Fernández-Izquierdo, 2017). Previous studies cite a lack of research on an integrative sustainability approach (Haughton, 1999; Moran, Wackernagel, Kitzes, Goldfinger, \& Boutaud, 2008; Perez, 2011; Saint-Supéry Ceano-Vivas,

Muñoz-Torres, \& Rivera Lirio, 2014). With the aim of filling this research gap, the current study addresses the following research question: To what extent are MFIs integrating financial, environmental, social and governance (FESG) criteria in their performance to foster sustainable development (SD)?

Through different clustering processes and characterization methods, we have analyzed the various sustainability indicators (SIs) reported by MixMarket. Based on this analysis, this work: (i) determines three different sustainability profiles of MFIs, (ii) underscores the aspects where the MFIs need to focus to become more sustainable and (iii) provides information at sectorial level, distinguishing which attributes characterize MFIs according to their sustainability profile.

The remainder of the paper is organized as follows: Section 2 surveys the most relevant related works on this field and Section 3 describes the research design and methods applied along the empirical analysis. The clustering results, profiling and characterization are presented in Section 4. Section 5 contains the discussion and concluding remarks are in Section 6.

\section{Literature review}

Our literature review has been conceived in accordance with the concept-centric approach proposed by Webster and Watson (2002). The identification of the terms 
emerges from the research question and is performed considering an inductive approach (Zhang \& Wildemuth, 2009), with no fixed categories or previous expectations.

The key words in this work are "microfinance institutions" and "sustainable development," but because many papers address the issue from a broader perspective, terms such as "corporate social responsibility" (CSR), "ethics" and "environmental" have been included to better capture the positioning of MFIs. From the combination of these concepts and previous surveys, we will relate how previous studies do or do not consider FESG issues connected to MFIs' performance and their role in SD.

For the material collection, we have considered English and Spanish articles from the academic database Web of Science, from 2005 to October 2017, in which the concept "microfinance institutions" appears in the topic accompanied by "sustainable development," "CSR," "ethics," or "environmental." The choice of 2005 as the initial date is because it was the Year of Microcredit proclaimed by the United Nations Economic and Social Council and since then papers covering microfinance have grown noticeably (García-Pérez et al., 2017). To ensure the inclusion of relevant literature, we have applied the same criteria in the Google Scholar search engine, and after eliminating duplicates, the result is that 63 articles were selected as relevant publications to develop the theoretical framework of this paper.

SD integrates the commitment of societal evolution toward a more equitable and wealthy world for generations to come (Brundtland, 1987). This prospect of social and economic prosperity collides with the threat of unprecedented social-ecological consequences resulting from economic activity transgressing planetary boundaries (e.g. Dyllick \& Hockerts, 2002; Rockström et al., 2009; Steffen et al., 2015).

To operationalize this complex and multidisciplinary concept, academics and practitioners have addressed sustainability from different perspectives (Lozano, 2008). Common principles and characteristics usually underlie these diverse approaches (Flint, 2013). To contribute to the universal implementation of sustainability, enlightening principles should be established and serve as the basis fora transdisciplinary theoretical 
framework of sustainability (Glavic \& Lukman, 2007).

In this vein, the Triple Bottom Line (TBL) concept (Elkington, 1997) provided a seminal contribution to the interrelation of the three dimensions of sustainabilityfinancial, environmental and social—founded on a balance among the aims of social equity (People), environmental respect (Planet) and economic progress (Profit).

As an evolution of the original TBL framework, when assessing a firm's sustainability, it is crucial to combine optimally the governance mechanisms (Galema, Lensink, \& Mersland, 2012; Hartarska, 2005; Mersland \& Str0m, 2009) for improving good corporate governance (Ferrero-Ferrero, Fernández-Izquierdo, \& Muñoz-Torres, 2015) and achieving optimal transparency, participation and accountability in its governance systems (Bakker, Schaveling, \& Nijhof, 2014; Kolk, 2008).

That is, SD entails four interdependent dimensions-financial, environmental, social and governance - and strikes an appropriate balance among them (Gladwin, Kennelly, \& Krause, 1995; Starik \& Kanashiro, 2013) in the short and long term (Elsen, 1998; Lozano \& Huisingh, 2011).

The term MFI usually refers to an organization that provides financial inclusion to low-income clients through different services such as microcredit, microinsurance, microsavings and money transfers (Ledgerwood, 1999; van Rooyen, Stewart, \& de Wet, 2012). The most characteristic features of these institutions are related to the origin of their funds, the use of nontraditional risk evaluation methodologies and the fact that they are usually located in low-income countries with poor and informal business infrastructure.

Some previous studies had merged both approaches to explore sustainable finance in the microfinance sector (Forcella \& Hudon, 2016; García-Pérez et al., 2017; Ramaswamy \& Krishnamoorthy, 2016). Considering academic research, when combining SD in its broad concept with MFIs, the selected articles show the following: 
In this field, SD is often related to the sustainability of the MFI for the development of their activity and goals (Perez, 2011). That is, the sustainability of the MFIs is circumscribed to operational and financial sustainability (e.g. Hermes \& Lensink, 2007; Hartarska \& Nadolnyak, 2008; Quayes, 2012; among others). When considering the FESG dimensions of sustainability, there is a close relation between social and economic spheres (Cull, Demirgûç-Kunt, \& Morduch, 2009; García-Pérez et al., 2017; GutiérrezNieto, Serrano-Cinca, \& Molinero, 2007). In articles in which financial issues prevail, on the one hand there is a latent interest in the impact on the social aspects that relate this sector and its performance to social and financial inclusion (Jose \& Chacko, 2017; Lacalle-Calderón, Alfonso-Gil, \& Rico-Garrido, 2015; Prior \& Argandoña, 2009) and poverty alleviation (Kunal, 2013; Manta, 2016; Tashman \& Marano, 2009). On the other hand, there is community impact (Perez, Gonzalez, \& Aaronson, 2011; Warnecke, 2014), particularly in women's lives (Chakrabarty \& Bass, 2014; Maclean, 2010; Warnecke, 2015), the prevention of overindebtedness (Hudon, 2009; Rahman, 1999; Sathye, Mukhopadhyay, \& Sathye, 2014) and discussion of the mission drift problem (Arena, 2007; Kunal, 2013; Lopatta et al., 2017).

In addition to the double bottom line-financial, social—-some studies establish an economic-social-environmental nexus (e.g. Chirambo, 2017; Raha, Mahanta, \& Clarke, 2014; Wijesiri \& Meoli, 2015)

Works such as Allet (2014) and Allet and Hudon (2015) aim to highlight this third dimension, identifying, on the one hand, the reasons why MFIs decide to promote environmentally friendly practices and, on the other, the characteristics of the MFIs involved in environmental management. Their results show that the more social responsible the institution, the more proactive and innovative in the environmental sphere it will be. Furthermore, they also emphasize that profitability of the MFI is unlikely to be affected by performing green practices. In the same sense of underlining the environmental dimension, Serrano-Cinca, Gutiérrez-Nieto, and Reyes (2016) propose that creditworthiness evaluations from MFIs should be coherent with their social mission and how these organizations can include social and environmental issues in their decisionmaking systems. Thereby, achieving the alignment of the TBL dimensions thus avoids 
mission drift.

The financial-social-governance combination is presented in works such as Arena (2007) where the efforts of social corporate governance mechanisms are compared with traditional efforts toward the minimization of the effect of mission drift of the socially oriented MFIs when achieving financial sustainability.

Ramaswami, Zimmerman, and Mihelcic (2007) focus on the transfer of knowledge for SD. Here, microfinance emerges as a tool for the economic axis, along with the governance structures and the community participation as a social strategy. They conclude that only an understanding of these three systems would allow the necessary technological development for SD.

Ethical issues also arise in several works, exploring how MFIs deal with ethical practices toward financial sustainability, social outreach and social responsibility (Chiu, 2014; Sathye et al., 2014), the analysis of ethics codes for social enterprises (Kleynjans \& Hudon, 2016), or supporting how MFIs build positive ethical strength in negative contexts (Chakrabarty \& Bass, 2014).

The studies of Ramaswamy and Krishnamoorthy (2016) and Warnecke (2015) discuss the relationship between microfinance and the three traditional dimensions of sustainability; in addition, both propose governance actions such as those related to management, environmental impact assessment processes, regulatory structures, and green policies that define the environmental approach of the institution, thus including the fourth FESG dimension.

\section{Research design}

The description of the research design accomplished in this article is presented below. Figure 1 schematically shows the content of the three main stages on which the structure of the work is based. Then, each of the actions performed is detailed in the 


\section{Microfinance Institutions Fostering Sustainable}

Development

sample design, the analytical process and the results.

Figure 1. Research design scheme

\section{Research Design}
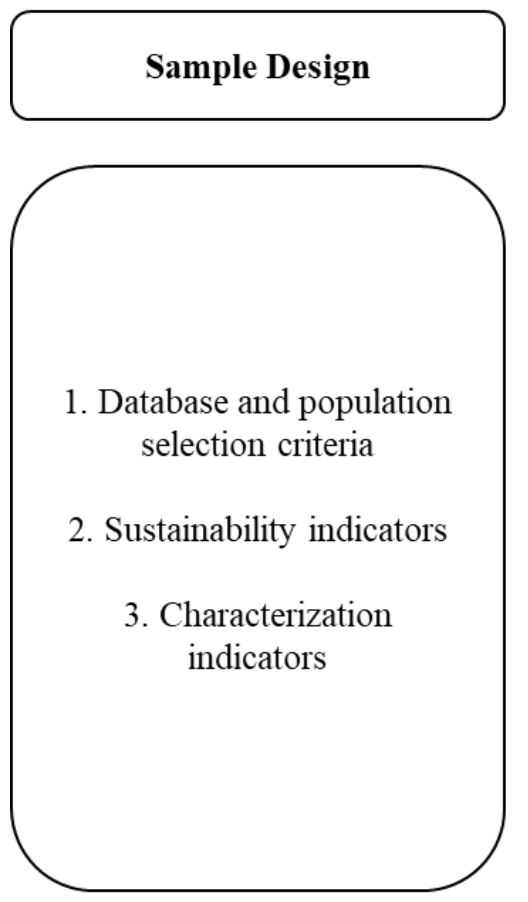

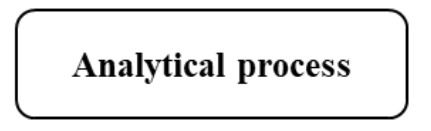

Descriptive statistics

External Logistic Biplot

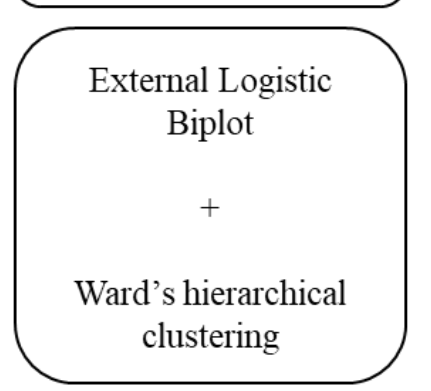

Kruskal-Wallis $H$ test

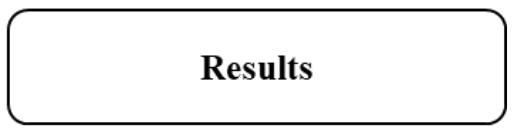

Descriptive analysis of the sample and the sustainability indicators

Relationship between sustainability indicators

Clustering organizations according to the sustainability profile

Characterizing organizations according to the sustainability profile

\subsection{Sample design}

Consistent with previous research, the current analysis is based on the MixMarket database (Cull et al., 2009; García Pérez \& Muñoz Torres, 2015; Hartarska \& Nadolnyak, 2008). The first criterion for selection of the sample is an acceptable level of disclosure quality. The MixMarket database provides a rating, called diamonds, that ranges from 1 to 5 , where 5 is the highest disclosure standard and transpar ency (see http://www.themix.org). The minimum diamond level considered in this research is 3 , as the selection of more reliable data increases the quality level of the results (Hartarska, 2005; Tchakoute- Tchuigoua, 2010).

For the selection of the SIs, we first considered the literature on microfinance FESG performance evaluation along the four dimensions. The first dimension, "Financial 
performance," is one of the most frequently measured with indicators that belong to different categories such as revenues, expenses, efficiency, productivity, risk and liquidity. For financial sustainability, the indicator chosen considers the ability of the MFI to maintain and expand the supply of financial services by generating the net income needed to cover its costs (Rosenberg, 2009).

For the second dimension, "Environmental performance," the Microfinance Environmental Performance Index (MEPI) framework (Allet, 2011; Forcella \& Hudon, 2016) was considered. This index adapts the extent of "Environmental policy," "Ecological footprint," "Environmental risk assessment," "Green microcredit" and "Environmental non-financial services" to the microfinance sector context. In this regard, both direct and indirect environmental impacts of MFI management have been taken into account.

For selection of the "Social performance" dimension indicators, four areas were taken into account: target market, development goals, products and services offered, and client protection. These areas coincide with those proposed by the Social Performance Task Force (SPTF) and with indicators contemplated by, for example, Sinha (2006), Copestake (2007), or Lapenu, Konini, and Razakaharivelo (2009), among others.

The fourth dimension, "Governance performance," includes indicators related to internal governance mechanisms, as board commitments and composition (Bakker et al., 2014; Hartarska \& Nadolnyak, 2011; Mersland \& Str0m, 2009) and human resource policies of the staff (Kleynjans \& Hudon, 2016).

The MixMarket database provides SIs for the FESG dimensions. All these voluntarily reported SIs take the value of 1 when the MFI indicates that the attribute is being considered and 0 if it is not. The MFIs selected should have FESG information available and have no missing values.

According to MixMarket, the definitions of the SIs are founded on the six dimensions proposed by the Universal Standards for Social Performance Management (USSPM) and could be directly connected to different principles and standards such as 
from the Organization for Economic Co-operation and Development (OECD), United Nations Global Compact (UNGC), United Nations Human Rights (UNHR) and Client Protection Certification Standards (CPCS), the Smart Campaign Client Protection (SCCP) or the Planetary Boundaries (PB) (Steffen et al., 2015) that define the environmental limits that should not be transgressed to operate safely.

To categorize and classify the SIs (see Table 1), a code was assigned to each indicator and organized according to the FESG dimension to which it corresponded. Likewise, they were related to the 17 proposed Sustainable Development Goals (SDGs) stakeholder action-oriented agenda; these provide an integrated and universal vision for ending extreme poverty, reducing inequalities and protecting the planet. The SIs are also adjusted to the Global Reporting Initiative (GRI) guidelines, which offer an adaptive framework for sustainability reporting (Azapagic, 2003; Bouten, Everaert, Van Liedekerke, De Moor, \& Christiaens, 2011) and a consensual structure for the SI categorization (García-Pérez et al., 2017).

To provide information at the sectoral level, we characterize the MFIs through the 62 most distinctive indicators of the microfinance sector available in the MixMarket database (MixMarket, 2014). These indicators belong to different categories: institutional characteristics, overall financial performance, revenues, expenses, efficiency, productivity, risk and liquidity.

Table 1. Description of the SIs in the analysis. 
SI SUSTAINABILITY INDICATOR DEFINITION

USSPM SDGS PRINCIPLES

GRI FINANCIAL

\begin{tabular}{|c|c|c|}
\hline \multirow[t]{2}{*}{ FC1 } & \multicolumn{2}{|l|}{ The MFI is Financial Self-Sufficient } \\
\hline & \multicolumn{2}{|l|}{ ENVIRONMENTAL } \\
\hline \multirow{3}{*}{ EN1 } & & \multirow{5}{*}{\begin{tabular}{|l}
\multicolumn{1}{|c}{ PB } \\
Climate change; \\
novel entities; \\
stratospheric \\
ozone depletion; \\
atmospheric \\
aerosol loading; \\
ocean \\
acidification; \\
biogeochemical \\
flows; freshwater \\
use; land-system \\
change; biosfere \\
integrity
\end{tabular}} \\
\hline & $\begin{array}{l}\text { The institution offers specific loans linked to } \\
\text { environmentally friendly products and/or practices }\end{array}$ & \\
\hline & $\begin{array}{l}\text { The institution uses specific tools to evaluate the } \\
\text { environmental risks of clients' activities (categorizing } \\
\text { client risk levels by sector, surveying environmental } \\
\text { impacts, use of an exclusion list, etc.) }\end{array}$ & \\
\hline EN3 & $\begin{array}{l}\text { The institution includes clauses in loan contracts that } \\
\text { require clients to improve environmental } \\
\text { practices/mitigate environmental risks }\end{array}$ & \\
\hline EN4 & $\begin{array}{l}\text { The institution conducts activities related to raising } \\
\text { awareness of environmental impacts, such as: } \\
\text { running training sessions and discussions, displaying } \\
\text { posters, distributing flyers, etc. }\end{array}$ & \\
\hline
\end{tabular}

\begin{tabular}{|l|l|l|l|}
\hline DIM. 6 & & OECD & G4-EC1 \\
\hline
\end{tabular}

\begin{tabular}{|l|l|}
\hline \multicolumn{2}{|c|}{ SOCIAL } \\
\hline SC1 & The MFI measures client poverty \\
\hline
\end{tabular}

\begin{tabular}{l|l}
\hline $\mathrm{SC} 2$ & The MFI has very poor clients and poor clients as a target market \\
\hline
\end{tabular}

SC3 1 The MFI has Women as a target market

SC4 The MFI has Adolescents and youth (below 18) as a target market

SC5 $\quad$ The MFI has Clients living in urban areas as a target market

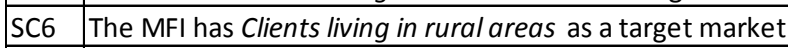

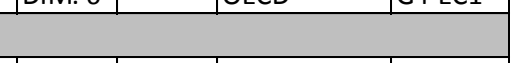

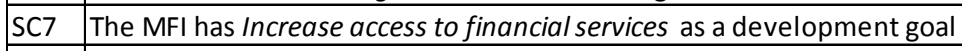

SC8 The MFI has Poverty reduction as a development goal

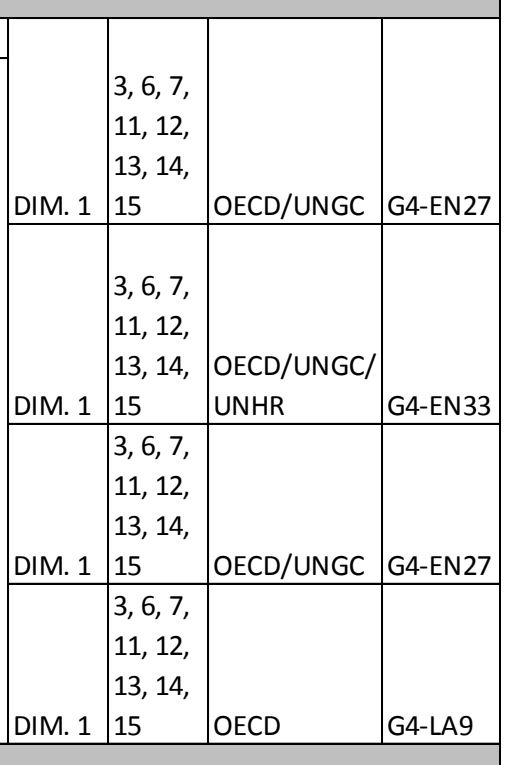

SC9 The MFI has Employment generation as a development goal

\begin{tabular}{|l|l|l|l|} 
DIM. 1 & 1,2 & OECD/UNGC & G4-SO1 \\
\hline
\end{tabular}

SC10 The MFI has Development of start-up enterprise as a development goal

SC11 The MFI has Growth of existing businesses as a development goal

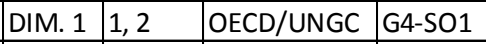

\begin{tabular}{|l|l|l|l|}
\hline DIM. 1 & 1,2 & OECD/UNGC & G4-SO1 \\
\hline & 5 & OECD/UNGC & G4-SO1 \\
\hline
\end{tabular}

SC12 The MFI has Improvement of adult education as a development goal

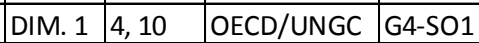

SC13 1 The MFI has Youth opportunities as a development goal

SC14 The MFI has Children's schooling as a development goal

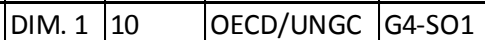

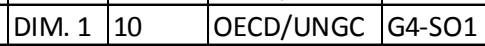

\begin{tabular}{|l|l|l|l|} 
DIM. 1 & 10 & OECD/UNGC & G4-SO1 \\
\hline
\end{tabular}

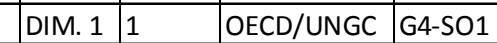

\begin{tabular}{|l|l|l|l|} 
DIM. 1 & 8 & OECD/UNGC & G4-SO1 \\
\hline
\end{tabular}

\begin{tabular}{|l|l|l|l|} 
DIM. 1 & 8 & OECD/UNGC & G4-SO1 \\
\hline
\end{tabular}

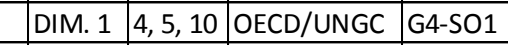

SC15 The MFI has Health improvement as as development goal

The MFI has Gender equality and women's empowerment as a

SC16 development goal

\begin{tabular}{|l|l|l|l|} 
DIM. 1 & 4,8 & OECD/UNGC & G4-SO1 \\
\hline
\end{tabular}

\begin{tabular}{|l|l} 
SC17 & The MFI has Water and sanitation as a development goal
\end{tabular}

\begin{tabular}{ll|l|l|} 
DIM. 1 & 4 & OECD/UNGC & G4-SO1 \\
\hline
\end{tabular}

SC18 The MFI has Housing as a development goal

SC19 The MFI offers Women's empowerment services

DIM. 1

OECD/UNGC G4-SO1

SC20 The MFI offers Other education services

\begin{tabular}{|l|l|}
\hline SC21 & The MFI offers Health services \\
\hline$S C 22$ &
\end{tabular}

\begin{tabular}{|l|l|}
\hline SC22 & The MFI offers Entreprise services \\
\hline$S C 23$ & The MFI client protecion includes a
\end{tabular}

DIM. 1

\begin{tabular}{|l|l|l|}
3 & $\mathrm{OECD} / \mathrm{UNGC}$ & $\mathrm{G} 4-\mathrm{SO} 1$ \\
\hline
\end{tabular}

SC23 The MFI client protection includes a Robust repayment evaluation

The MFI client protection includes Internal audits verify over-

SC24 indebtedness prevention

\begin{tabular}{|l|l}
\hline & The MFI client protection includes a Full disclosure of prices, terms and
\end{tabular}

SC25 conditions

SC26 1 The MFI client protection includes Clear debt collection practices

DIM. 1 5, 8, 10 OECD/UNGC G4-SO1

\begin{tabular}{l|l|l|l|} 
DIM. 1 & 6 & OECD/UNGC & G4-SO1 \\
\hline
\end{tabular}

\begin{tabular}{|l|l|l|l|}
\hline DIM. 1 & 6 & OECD/UNGC & G4-SO1 \\
\hline DIM. 1 & 2,6 & OECD/UNGC & G4-SO1 \\
\hline
\end{tabular}

\begin{tabular}{|l|l|l|l|} 
DIM. 3 & 5,8 & OECD/UNGC & G4-SO1 \\
\hline
\end{tabular}

The MFI client protection includes a Functioning client complaint in loan

SC27 contract

\begin{tabular}{|l|l}
\hline The MFI uses the Declining balance interest method for the Interest rate \\
\hline
\end{tabular}

SC28 calculation

DIM. 34

OECD/UNGC 1 G4-SO1

\begin{tabular}{|l|l|l|l|} 
DIM. 3 & 3 & OECD/UNGC & G4-SO1 \\
\hline
\end{tabular}

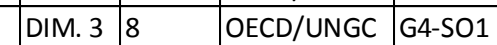

\begin{tabular}{|c|c|c|c|}
\hline DIM. 4 & 8 & $\mathrm{OECD} / \mathrm{SCCP}$ & G4-PR3 \\
\hline DIM. 4 & 8 & $\mathrm{OECD} / \mathrm{SCCP}$ & G4-PR3 \\
\hline DIM. 4 & 8 & $\mathrm{OECD} / \mathrm{SCCP}$ & G4-PR3 \\
\hline DIM. 4 & 8 & $\mathrm{OECD} / \mathrm{SCCP}$ & G4-PR3 \\
\hline DIM. 4 & 8 & $\mathrm{OECD} / \mathrm{SCCP}$ & G4-PR3 \\
\hline DIM. 4 & 8 & OECD/SCCP & G4-PR3 \\
\hline
\end{tabular}




\section{Microfinance Institutions Fostering Sustainable}

\section{Development}

\section{Capítulo III}

\begin{tabular}{|c|c|c|c|c|c|}
\hline SI & SUSTAINABILITY INDICATOR DEFINITION & USSPM & SDGs & PRINCIPLES & GRI \\
\hline & \multicolumn{5}{|l|}{ GOVERNANCE } \\
\hline GV1 & The MFI Board has an orientation on social mission and goals & DIM. 2 & 16 & & G4-34 \\
\hline GV2 & The MFI has a SPM champion and/or SPM committee on board & DIM. 2 & 16 & & G4-38 \\
\hline GV3 & The MFI has Board members with SP education and/or work experience & DIM. 2 & 16 & & G4-38 \\
\hline GV4 & The MFI staff incentives are not based on the Number of clients & DIM. 4 & 10,16 & SCCP & G4-51 \\
\hline GV5 & $\begin{array}{l}\text { The MFI staff incentives are based on the Quality of interaction with } \\
\text { clients based on client feedback mechanism }\end{array}$ & DIM. 4 & 10,16 & SCCP & G4-51 \\
\hline GV6 & The MFI staff incentives are based on the Quality of social data collection & DIM. 4 & 10,16 & & G4-51 \\
\hline GV7 & The MFI staff incentives are based on the Portfolio quality & DIM. 4 & 10,16 & SCCP & G4-51 \\
\hline GV8 & $\begin{array}{l}\text { The MFI human resource policies include Social protection (medical } \\
\text { insurance and/or pension contribution) }\end{array}$ & DIM. 5 & $\begin{array}{l}8,10 \\
16\end{array}$ & OECD & G4-LA8 \\
\hline GV9 & The MFI human resource policies include a Safety policy & DIM. 5 & \begin{tabular}{|l|}
$, 8,8$ \\
10,16 \\
\end{tabular} & OECD & G4-LA8 \\
\hline GV10 & The MFI human resource policies include an Anti-harassment policy & DIM. 5 & \begin{tabular}{|l|}
$, 8,8$ \\
10,16 \\
\end{tabular} & \begin{tabular}{|l|} 
OECD/UNGC/ \\
UNHR
\end{tabular} & G4-HR3 \\
\hline GV11 & The MFI human resource policies include a Non-discrimination policy & DIM. 5 & $\begin{array}{l}, 8 \\
10,16 \\
\end{array}$ & $\begin{array}{l}\text { OECD/UNGC/ } \\
\text { UNHR }\end{array}$ & G4-HR3 \\
\hline
\end{tabular}

Source: own work

To provide information at the sectoral level, we will characterize the MFIs through the 62 most distinctive indicators of the microfinance sector available in the MixMarket database (2014). These indicators belong to different categories: institutional characteristics, overall financial performance, revenues, expenses, efficiency, productivity, risk and liquidity.

\subsection{Analytical process}

As a preliminary step, a univariate analysis of the sample and the SIs was conducted. This technique is commonly used in studies where the objective is to assess the overall status of the microfinance sector or assess it at a specific economic, social, environmental or governance level (Ashta, Khan, \& Otto, 2015; Gertler, Levine, \& Moretti, 2009; Mersland \& Str0m, 2009; Morduch, 1999).

The External Logistic Biplot (ELB) algorithm is a dimensionality reduction factorial method suitable for binary data. This algorithm determines the principal components that define a whole set of observed items and adjusts a logistic regression model. ELB will explain the relationship between SIs and the correlation between the different MFIs. The main rules for the plot interpretation include similarity of subjects (MFIs), length and direction of the vector (SIs), and angle and cosines between vectors. For more detailed information on the geometric properties, see Gallego-Álvarez and 
Vicente-Villardón (2012) or Torres-Salinas, Robinson-García, Jiménez-Contreras, Herrera, and López-Cózar (2013).

This algorithm was proposed by Vicente-Villardón, Galindo-Villardón, and Blázquez-Zaballos (2006) and its application includes different fields of study: analysis of performance innovation (de Noronha Vaz, Galindo, de Noronha Vaz, \& Nijkamp, 2015) and sustainability studies (Gallego-Álvarez, Galindo-Villardón, \& RodríguezRosa, 2015; Vicente Galindo, Vaz, \& de Noronha, 2015), among others.

Once the relationship between the different SIs is established, Ward's hierarchical clustering method will define the different MFI groups according to the sustainability profile. Ward's minimum variance method (Ward Jr., 1963) is an iterative process that reduces a set of elements to a prefixed number of mutually exclusive subsets.

To determine the number of clusters, a dendrogram has been applied. A vertical axis shows the dissimilarity between clusters, a horizontal axis represents the objects and clusters. The number of groups will be defined by the maximum dissimilarity between groups, represented by the length of the vertical branches (Ferro-Luzzi \& Weber, 2006; Serrano-Cinca, Gutiérrez-Nieto, \& Molinero, 2011).

To determine the indicators that significantly characterize the sustainability profiles, this nonparametric test determines if there are statistically significant differences between two or more groups (Kruskal \& Wallis, 1952) of an independent variable on a continuous or ordinal dependent variable. This methodology has been used specifically in studies of microfinance (Holvoet, 2005; Rai, 2015; Tchakoute-Tchuigoua, 2010) when data without a normal distribution and/or heterogeneous variance of the population is analysed.

The programs used were: MultBiplot software (Salamanca, Spain) to implement the ELB algorithm, Ward's clustering method and the IBM SPSS Statistics v.22.0 software package (IBM Corp., Armonk, NY, USA) for the dendrogram graphic representation and the Kruskal-Wallis H-test. 


\section{Results}

\subsection{Descriptive analysis of the sample}

The sample includes a total population of 3,416 MFIs registered in the MixMarket database in 2014 and is based on 148 MFIs for which the disclosure quality is equal to or above the average and for which there is adequate reporting of the SIs. As shown in Table 2 , the number and percentage of institutions, by region, varies along the consecutive phases depending on the fulfillment of the corresponding requirements.

Table 2. Number and percentage of MFIs in each step of the selection process and their distribution by region

\begin{tabular}{|l|r|r|r|r|r|r|}
\cline { 2 - 7 } \multicolumn{1}{c|}{} & \multicolumn{2}{c|}{ Total population } & \multicolumn{2}{c|}{$\begin{array}{c}\text { Quality of } \\
\text { disclosure equal to } \\
\text { or above the } \\
\text { average }\end{array}$} & \multicolumn{2}{c|}{$\begin{array}{c}\text { Sustainability data } \\
\text { available }\end{array}$} \\
\cline { 2 - 8 } & $\mathbf{N}$ & $\mathbf{\%}$ & $\mathbf{N}$ & $\mathbf{\%}$ & $\mathbf{N}$ & $\%$ \\
\hline Africa & 920 & 26.93 & 9 & 2.91 & 3 & 1.29 \\
\hline $\begin{array}{l}\text { Latin America and } \\
\text { the Caribbean }\end{array}$ & 845 & 24.74 & 247 & 79.94 & 108 & 72.97 \\
\hline $\begin{array}{l}\text { Eastern Europe } \\
\text { and Central Asia }\end{array}$ & 553 & 16.19 & 18 & 5.83 & 12 & 8.11 \\
\hline South Asia & 503 & 14.72 & 12 & 3.88 & 9 & 6.08 \\
\hline $\begin{array}{l}\text { East Asia and the } \\
\text { Pacific }\end{array}$ & 473 & 13.84 & 17 & 5.50 & 12 & 8.11 \\
\hline $\begin{array}{l}\text { Middle East and } \\
\text { North Africa }\end{array}$ & 117 & 3.43 & 6 & 1.94 & 4 & 2.70 \\
\hline North America & 4 & 0.12 & & & & \\
\hline Western Europe & 1 & 0.03 & & & & \\
\hline
\end{tabular}

Initially, the allocation of MFIs by region was relatively evenly distributed. Latin America and Africa have 27\% and 25\% distributions, respectively, and Eastern Europe, Central Asia, South Asia, and East Asia and the Pacific all have an approximate distribution of $15 \%$. Significant changes occur when introducing the quality of reporting and the availability of sustainable data criteria. The total population is reduced to $95 \%$, and distribution varies noticeably; the Latin America region becomes the most 
represented area (73\%), while the Africa and South Asia regions are drastically reduced. In the first case, of the 920 MFIs registered, only 3 report beyond general information and outreach data and provide sustainability information; in the second, $98 \%$ do not meet the quality or data availability requirements.

Most of the MFIs present in the sample are non-profit institutions (63.5\%), and their legal statuses are non-governmental organizations (NGOs) (48\%), non-bank financial institutions (NBFI) (30\%) and to a lesser degree, banks (12\%) and credit unions, cooperatives and rural banks (10\%). The presence of MFIs subject to a regulatory authority, such as a formal banking regulator or another financial services regulator, has no significant differences: $52 \%$ are regulated and $48 \%$ are not. In terms of maturity and size, the MFIs analyzed are mature (93\%) with more than 8 years, and the size is spread relatively evenly, with $36 \%$ of large size (more than 100 employees), $26 \%$ of medium size (20-99 employees) and 38\% of small size (5-19 employees).

\subsection{MixMarket sustainability indicators' (SIs) descriptive analysis}

The microfinance sector has focused its study on socio-economic aspects with particular attention to financial sustainability (exclusively) and its impact on society from the perspective of poverty reduction, reduction of gender inequalities or employment promotion, among others, which explains the high number of social indicator variables in the study. Less research has been done in the areas of governance and environment, and MFIs tend to report them to a lesser extent (García-Pérez et al., 2017), thus the number of indicators in these areas is much lower. The distribution of the different items of each dimension are shown in Figure 2. 


\section{Microfinance Institutions Fostering Sustainable}

Development

Figure 2. Spider graph with the percentage of financial (2a), environmental (2b), social (2c), and governance (2d) indicators reported for each SI

2a. Financial indicators

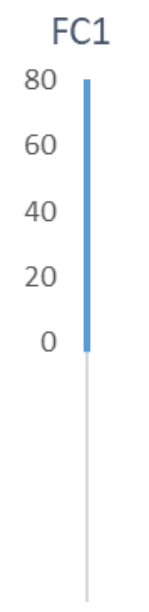

2c. Social indicators

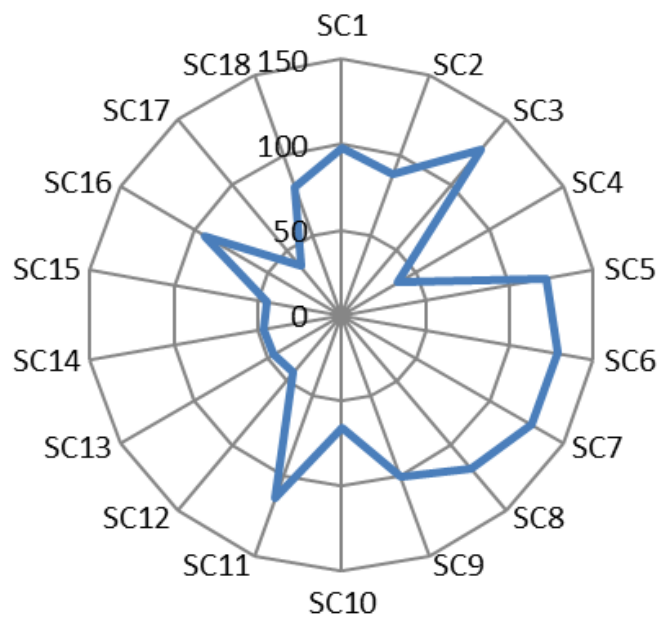

2b. Environmental indicators

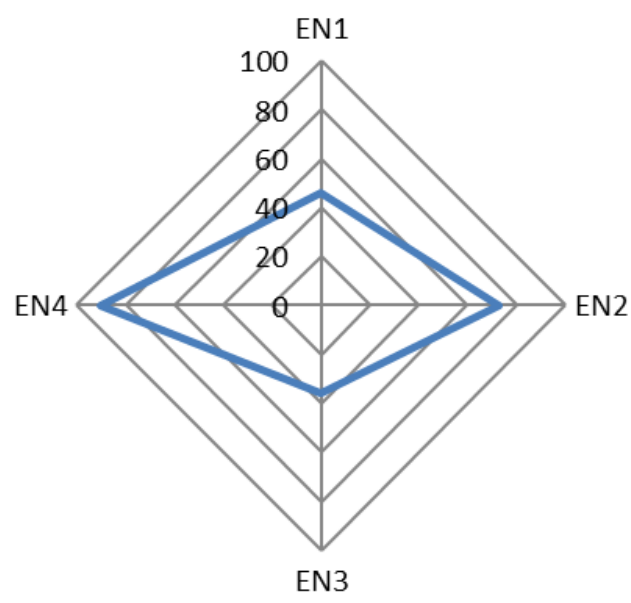

2d. Governance indicators

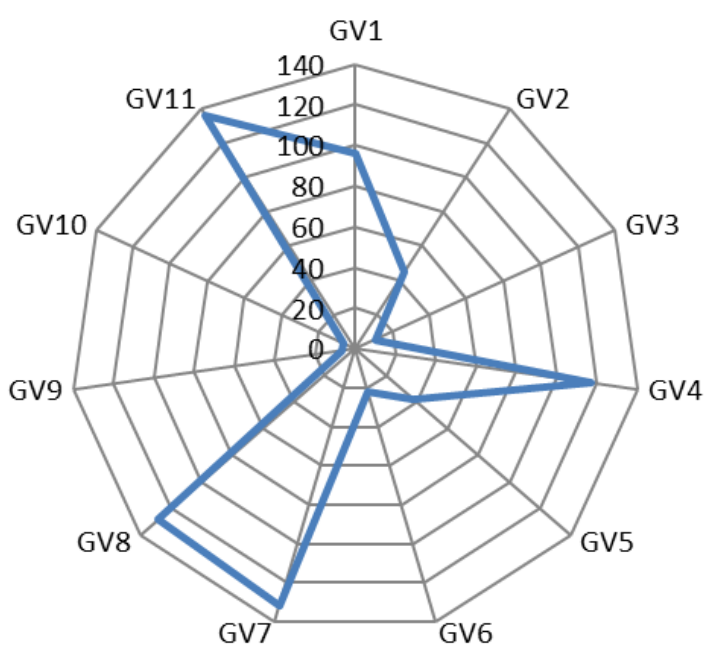

On average, $60 \%$ of the actions positively reported are from the social dimension, while $45 \%$ correspond to governance actions, and $41 \%$ are related to the environmental sphere. That is, although the set of social indicators is much larger than the remainder, the positive reporting of MFIs has a much smaller difference.

The economic SI considered shows that $80 \%$ of the MFIs are financially selfsufficient; that is, the institution has the ability to generate sufficient revenue to cover its costs (Cull et al., 2007). FC1 is the only economic binary variable, it is not directly 
reported by the MFIs, and it is calculated by MixMarket ${ }^{1}$. Considering the importance of the economic indicators, the remaining numeric economic indicators will be used in the characterization process of the institution.

The most reported social SIs are: SC25 (93\%) and SC23 (91\%); both are related to client protection, full disclosure of prices, terms and conditions and robust repayment evaluation. SC6 (87\%) clients live in rural areas as a target market; SC7 (87\%) indicates increase access to financial services as a development goal; and SC3 (86\%) targets women as the market. That is, nearly all MFIs consider these actions in the development of their business.

In addition, governance indicators have a high number of positive answers, where the main are: GV11 (91\%) and GV8 (86\%), human resource policies include a nondiscrimination policy and include social protection (medical insurance and/or pension contribution), and GV7 (89\%) and GV4 (79\%), the staff incentives are based on the portfolio quality and not in the number of clients. However, this dimension is very polarized: it presents answers with a high valuation but also presents the least valued of the 44 attributes. These are: GV6 (15\%), the staff incentives are based on the quality of social data collection, GV3 (7\%), board members have social performance education or work experience, and GV9 and GV10, both with $4 \%$ and both related to human resource policies, safety and anti-harassment policy.

The most disclosed environmental indicator is EN4 (60\%), the institution conducts activities related to raising the awareness of environmental impacts and the least disclosed is EN3 (24\%), clauses in loan contracts require clients to improve environmental practices/mitigate environmental risks.

\footnotetext{
${ }^{1} \mathrm{FC} 1$ is calculated as: adjusted financial revenue divided by the sum of adjusted financial expenses, adjusted net loan loss provision expenses, and adjusted operating expenses.
} 


\section{Microfinance Institutions Fostering Sustainable}

\section{Development}

\subsection{Relationship between sustainability indicators}

Figure 3 shows the graphical representation of the relationship between SIs according to the report of each MFI.

Figure 3. Biplot graphic of SIs arranged in the Euclidean space.

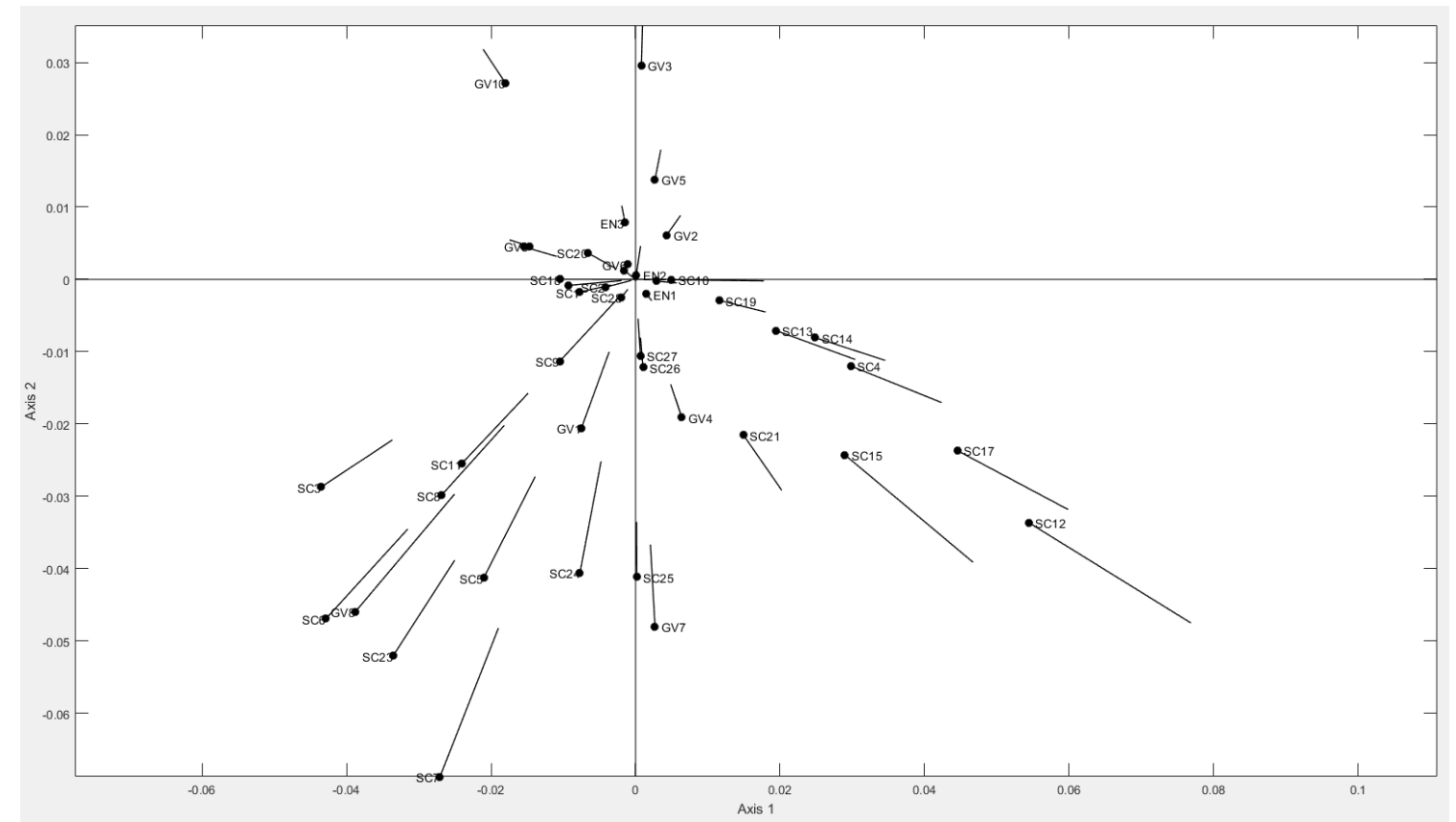

According to the main rules for the plot interpretation described in Section 3, the illustration shows that:

- The indicators with higher discriminating power are GV6, EN1, EN3 and EN4. There is a positive correlation between the staff receiving incentives based on the quality of social data collection (GV6) and the inclusion of loan clauses related to the improvement of the environmental practices (EN3), and between the offering of loans linked to environmentally friendly products (EN1) and the conducting of activities that raise awareness of environmental impacts (EN4). When one of the items of each pair is reported, the other is also reported. In addition, there is a negative correlation between the two pairs.

When an MFI reports that its incentives are based on the quality of social data 
collection (GV6), it also reports that the institution includes clauses in loan contracts that require clients to improve environmental practices (EN3). However, the MFI usually negatively reports that loan offers are linked to environmentally friendly products or services (EN1) or that the institution conducts activities related to raising awareness of environmental impacts (EN4).

- For the remainder of the indicators, there are different groups with high positive correlations. These groups are: adolescents and youth (SC4, SC13, and SC14), health and education (SC12, SC15, SC17, and SC21), client quality and protection (SC26, SC27, and GV7), poverty measure, the very poor and poor clients as the target market and gender equality and women`s empowerment (SC1, SC2, and SC16). There is only one strong inverse correlation between GV9 and GV11. When an MFI reports having a safety policy included for employees, the response is usually negative for including a nondiscrimination policy.

- Social indicators related to development goals (SC10, SC16, and SC18) are the most responsible for the MFI location in the plot.

\subsection{Clustering of MFI sustainability reporting profile}

The resulting number of clusters after analyzing the vertical longest branches of the dendrogram, as based on Ferro-Luzzi and Weber (2006), is three. The clustering graphic representation is shown in Figure 4, and the results obtained are described below. 
Figure 4. Graphic representation of the MFIs after applying Ward's hierarchical clustering.

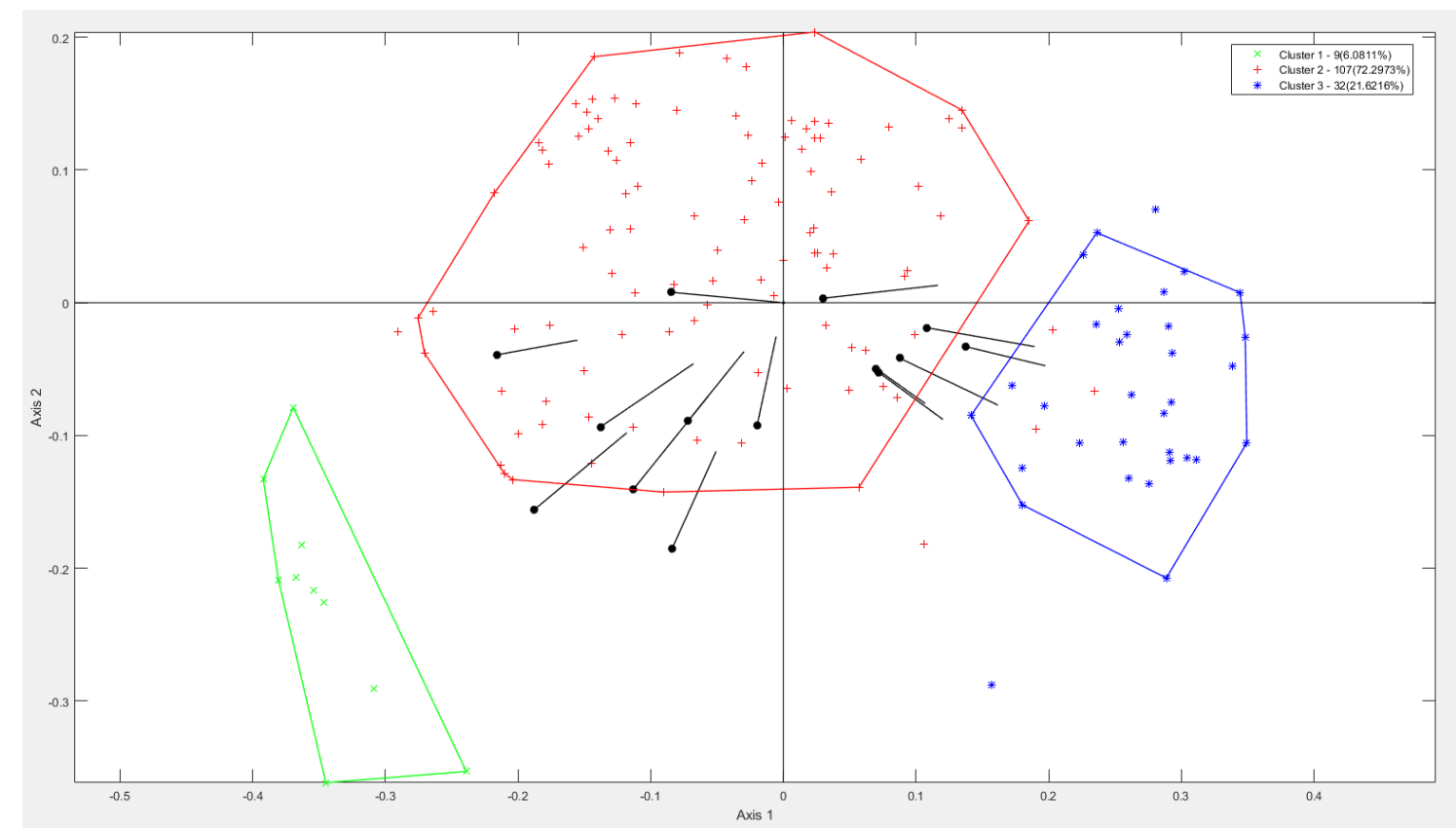

Cluster 1, formed by 16 MFIs (11\% of total), is the smallest group and has $13 \%$ more banks and NFBIs than the general average. The sustainability report profile of these institutions shows a small number of affirmative answers on economic and social variables. The overall average of the positive report on social actions is $52 \%$, whereas in this group, it is $17 \%$. Of the 28 social variables, 16 appear without reporting (SC3-SC18). In this group, no institution indicates that it has any explicit definition of the target market or establishes any development goals. However, despite the reduced involvement in social issues, there are variables that have $67 \%$ affirmative answers. These actions indicate that the MFIs perform the necessary actions to promote client protection from abusive practices including having a robust repayment evaluation (SC23), establishing clear debt collection practices (SC26), having a functioning client complaint procedure in the loan contract (SC27) and using the declining balance method to calculate the interest rate (SC28).

The area of governance has a lower result than the overall average, with $30 \%$ of positive responses compared to $40.5 \%$ globally. The MFIs all declare the inclusion of a 
non-discriminatory policy (GV11); more than half of the MFIs responded that the staff incentives are based on the portfolio quality and not on the number of clients (GV4 and GV7). Compared with the other groups, staff incentives are more frequent than the incentives that are based on the social quality of the data collection (GV6). However, no company indicates having a social mission-orientated board or having expert members on social performance (GV1 and GV3). Furthermore, in the human resources policies, none show plans associated with social protection or safety and anti-harassment policies (GV8, GV9, GV10).

The report on the environmental category is slightly above the overall average compliance with $47 \%$ positive reports. The variable with the highest percentage of responses is EN4 (67\%), which refers to the activities conducted by the MFI to raise awareness of the environmental impacts of their clients. Of the institutions in this group, $44 \%$ include clauses in the loan contracts that require clients to improve their environmental practices (EN3); this is more highly reported than in the rest of the groups.

Cluster 2 reflects the largest sustainability profile group, with 93 members, and comprises more than half of the surveyed institutions (63\% of total). The legal status is similar to the overall average distribution, with a majority of NGOs and NBFI. It is characterized by an affirmative answer to economics above the average (82\%), and social issues are in accordance with the overall average (55\%). There is slightly worse environmental behavior than the overall, with $39.5 \%$ positive answers compared to the $44 \%$ obtained in the total. In the governance area, the percentage of reported undertaken actions is above average; this is the group with the most positive responses to these issues $(47 \%)$.

Cluster 3 contains $26 \%$ of the sample, with 39 members. The presence of NGOs is $14.5 \%$ higher than the general average and has a lower participation of banks and NBFIs. These institutions' positive responses to the economic variables are slightly below the average $(77 \%)$. This sustainability profile has a markedly social nature. On average, social variables are reported in $85 \%$ of the cases, well above the $52 \%$ overall average. All the MFIs of this group consider women the target market (SC3) and establish gender equality 
and women's empowerment as development goals (SC16). These MFIs also consider poverty reduction and housing as the institution's objectives (SC8 and SC18) and fully disclose prices, terms and conditions to avoid abusive practices (SC25). In addition, 97\% of these MFIs declare the generation of employment, the growth of existing businesses, and the improvement of adult education and youth opportunities as development goals (SC9, SC11, SC12, and SC13). That is, this group of institutions has a strong social trend in which the main issues revolve around women and employment generation.

The behavior of the governance dimension variables is slightly better than average (44.5\% versus 40.5\%). Virtually all MFIs (94\%) have social protection and nondiscriminatory policies (GV8, GV11), and a very high percentage (81\%) declare that incentives are based on portfolio quality (GV7). However, there are variables to which none of the institutions respond affirmatively. That is, none of the MFIs declare having board members with social performance education or experience (GV3), and none have safety or anti-harassment policies (GV9, GV10).

Positive reporting in the environmental area is in accordance with the overall average $(46 \%)$. The performance indicator that is noteworthy, with a greater number of institutions, is EN4 (78\%): the institution conducts activities related to raising the awareness of environmental impacts. The least reported indicator is EN3 (22\%): in their loan contracts, the MFI includes requirements for clients to improve their environmental practices or mitigate environmental risks.

\subsection{MFI sustainability profile characterization}

The MixMarket database has 62 variables to characterize the MFIs. To determine which of these variables are significant, as explained in Section 3, the Kruskal-Wallis H test was applied.

Only four indicators were detected as significant: outreach, number of diamonds, assets and number of offices. The outreach in cluster 1 varies with respect to the behavior 


\section{Microfinance Institutions Fostering Sustainable}

Development

of the other two. In this case, the outreach, defined by MixMarket as "the goal of expanding access to financial services considering: Gross Loan Portfolio, Number of Active Borrowers, Deposits and Number of Depositors" is large. Of the institutions, $69 \%$ have a large outreach, while the overall average is $38 \%$. However, none of the 4 variables used for the calculation is significant when analyzed independently.

The number of diamonds shows that cluster 1 has $31 \%$ more MFIs of level 3, which makes this group the one with the lower level of transparency, while cluster 3 shows 12\% more MFIs than the general average at the highest levels of disclosure quality. Cluster 1 displays an average volume of assets per MFI that is three times higher than the general average; conversely, cluster 3 has, on average, half the assets per MFI than the average. Cluster 1 has, on average, nearly twice the offices per entity compared to the general average.

Figure 5 schematically shows the three MFI clusters, indicating their legal status, the four FESG dimensions and their level of commitment, and the significant variables that characterize the groups.

Figure 5. MFI sustainability profile characterization 


\section{Microfinance Institutions Fostering Sustainable}

\section{Development}

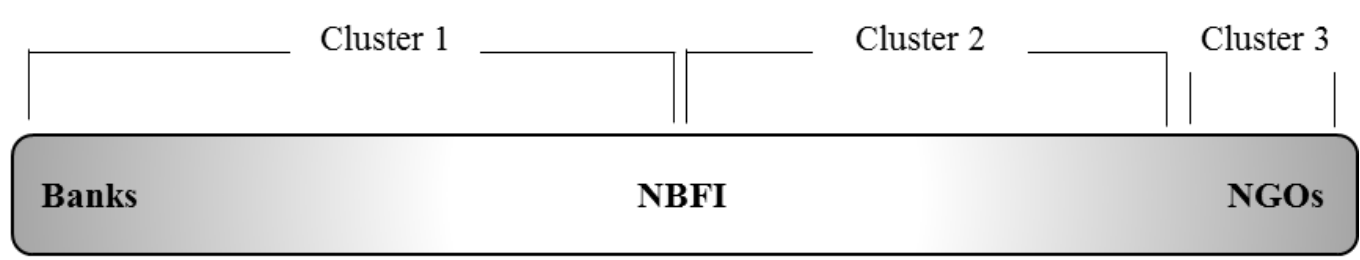

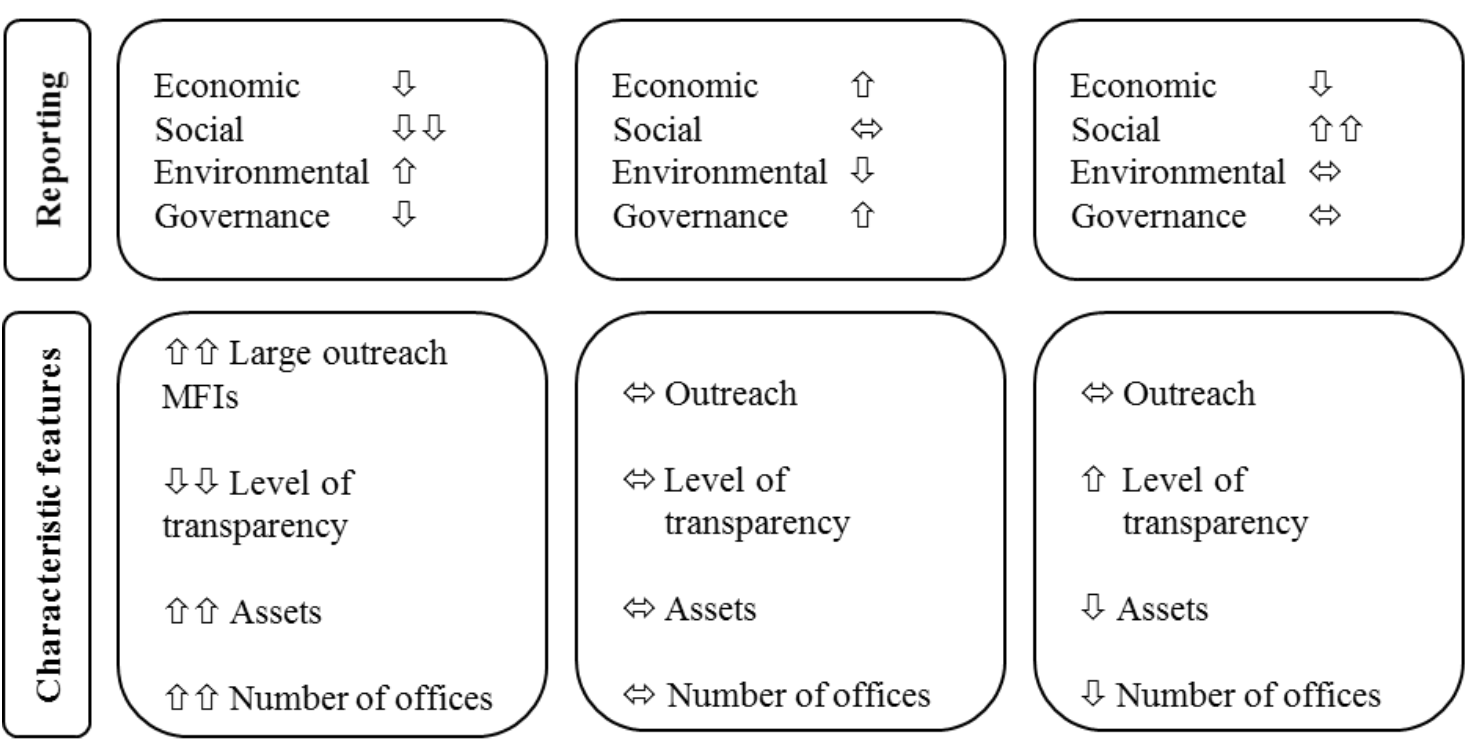
仓仓 Well above the average
$\checkmark$ Below the average
仓 Above the average
$\Leftrightarrow$ About the average
$\sqrt{\Omega}$ Well below the average

\section{Discussion}

In agreement with the literature, although social aspects are included in almost all MFIs' mission, for some organisations, financial self-sufficiency prevails over the rest of dimensions potentially causing a mission drift situation in socially oriented MFIs (Arena, 2007; Kunal 2013; Lopatta et al, 2017).

In this work, the set of indicators related to social issues is the most numerous. As in previous academic papers, the indicators that appear more frequently are those related to development goals of the MFI (Chirambo, 2017), client protection against overindebtedness (Rahman, 1999; Hudon, 2009; Sathye et al., 2014) and the effect of microfinance on women (Maclean, 2010; Warnacke, 2015) and gender equality (Chakrabarty \& Bass, 2014). 
The literature emphasizes the need to incorporate environmental responsibility as a key dimension of socially responsible investing (Chiu, 2014; Forcella \& Hudon, 2016). However, considering the results of this study, the environmental performance of MFIs is rarely reported, the processes conducted are poorly documented, and the indirect effects of their activity are unknown. Even considering the scarce sector's environmental performance, agreeing with the study presented by Allet and Hudon (2015), larger MFIs with bank legal status present a better environmental policy.

The same applies to the governance area, and despite the importance recognised in the academic field (Hartarska, 2005, Kolk, 2008, Mersland \& Strøm, 2009, among others), there is a small quantity of indicators to evaluate this dimension. This limitation grants great discriminating power to governance issues. That is, reporting governance actions provides a significant difference compared to the rest of institutions.

The results of this study also show a positive correlation between governance and environment indicators. This relationship, to our knowledge, is rarely included in the literature (García-Pérez et al., 2017), as these dimensions are usually related to the financial and social aspects.

Therefore, while in the FESG theoretical framework the balance of the four dimensions is addressed (Gladwin et al., 1995; Starik \& Kanashiro, 2013), when analysing MFIs, it is observed that this equilibrium does not exist and that microfinance sector continues to be characterized by a financial and social double bottom line scheme.

Our characterization, based on their sustainability profile under FESG criteria, complements previous research works, transferring the holistic and comprehensive analysis of sustainable investing to the microfinance sector appraisal.

\section{Conclusions}

Based on voluntary data reported by MFIs globally, the role of the MFIs in SD has 
been analysed with an integrative approach. Binary SIs that belong to the four FESG dimensions and with a definition in accordance to renowned principles and standards have been considered.

Social indicators are the most numerous, they are largely reported affirmatively and present a strong positive correlation among them. This makes some of these elements redundant and with low discriminating power. To promote the study of microfinance SD in an inclusive manner, it would be interesting to reduce and redefine social indicators and increase governance and environmental variables, as they have greater discriminatory power and would balance the representation of FESG dimensions. It would also be desirable the inclusion of qualitative and quantitative indicators of established procedures, protocols or resources involved in the process that allow a greater degree of deepening in the performance of different practices.

According to the three sustainability profiles that arises from the analysis, to improve the sustainability performance of the first group, consisting mainly of banks, it would be necessary to promote social and governance actions: define a target market, establish development goals, and revise the social orientation of the board or the human resources policies and procedures related to social protection or safety. The second group, comprising NBFI and NGO, should focus on environmental aspects, which consider the inclusion of requirements in loan contracts that aware of the risk of transgressing the planetary boundaries. The third group, formed principally by NGOs, needs to focus on environmental issues and governance mechanisms such as the composition of the board promoting the inclusion of members with social management experience and the addition of safety and anti-harassment policies.

In the sample studied, the large outreach, the high volume of assets or the large number of offices are significant indicators for the characterization of the different groups but are not associated with a better overall sustainability behaviour. Only quality of information is connected with sustainability behaviour as MFIs categorized with a higher level of disclosure quality develop better sustainability results, predominantly in the social area. 
It is also remarkable the fact that there are regions with a great number of organisations, but with a low quality of disclosure and unavailable sustainability data. For future research it would be desirable further information that allows the inclusion of more MFIs of Africa and South Asia regions.

Thus, this work incorporates the sustainability theoretical framework considered in sustainable finance as an advanced sustainability concept that integrates financial, environmental, social, and governance aspects in an integrative, steady and balanced approach for the assessment of MFIs worldwide.

This study provides deeper information at the sectoral level, categorizes MFIs globally and calls for greater transparency that could be beneficial to all stakeholders, including institutions, donors, policy makers and academics, to promote the development of sustainability management in the microfinance sector.

\section{Acknowledgment}

This paper is supported by European Union's Horizon 2020 Research and Innovation Programme under Grant Agreement No. 693642, project SMART (Sustainable Market Actors for Responsible Trade). Moreover, the authors would like to thank the editor and anonymous referees for their helpful comments.

\section{References}

Allet, M. (2011). Measuring the environmental performance of microfinance. Université Libre de Bruxelles.

Allet, M. (2014). Why do microfinance institutions go green? An exploratory study. Journal of Business Ethics, 122(3), 405-424.

Allet, M., \& Hudon, M. (2015). Green microfinance: Characteristics of microfinance institutions involved in environmental management. Journal of Business Ethics, 126(3), 395-414.

Arena, T. (2007). Social corporate governance and the problem of mission drift in socially-oriented microfinance institutions. Colum. JL \& Soc. Probs., 41, 269. 
Ashta, A., Khan, S., \& Otto, P. (2015). Does microfinance cause or reduce suicides? Policy recommendations for reducing borrower stress. Strategic Change, 24(2), 165-190.

Azad, M. A. K., Masum, A. K. M., Munisamy, S., \& Sharmin, D. F. (2016). Efficiency analysis of major microfinance institutions in Bangladesh: a Malmquist index approach. Quality \& Quantity, 50(4), 1525-1537.

Azapagic, A. (2003). Systems approach to corporate sustainability: a general management framework. Process Safety and Environmental Protection, 81(5), 303-316.

Bakker, A., Schaveling, J., \& Nijhof, A. (2014). Governance and microfinance institutions. Corporate Governance, 14(5), 637-652.

Beck, T., Demirgüç-Kunt, A., \& Levine, R. (2010). Financial institutions and markets across countries and over time: The updated financial development and structure database. The World Bank Economic Review, 24(1), 77-92.

Bouten, L., Everaert, P., Van Liedekerke, L., De Moor, L., \& Christiaens, J. (2011, September). Corporate social responsibility reporting: A comprehensive picture?. In Accounting Forum (Vol. 35, No. 3, pp. 187-204). Elsevier.

Brundtland, G.H. (1987). Our Common Future: Report of the 1987 World Commission on Environment and Development. United Nations, Oslo, pp. 1e59.

Busch, T., Bauer, R., Orlitzky, M. (2016). Sustainable development and financial markets: old paths and new avenues. Bus. Soc. 55 (3), 303e329.

Chakrabarty, S., \& Bass, A. E. (2014). Institutionalizing ethics in institutional voids: Building positive ethical strength to serve women microfinance borrowers in negative contexts. Journal of Business Ethics, 119(4), 529-542.

Chirambo, D. (2017). Enhancing Climate Change Resilience Through Microfinance: Redefining the Climate Finance Paradigm to Promote Inclusive Growth in Africa. Journal of Developing Societies, 33(1), 150-173.

Chiu, T. K. (2014). Putting responsible finance to work for Citi microfinance. Journal of Business Ethics, 119(2), 219-234.

$\begin{array}{llll}\text { Client } & \text { Protection } & \text { Certification }\end{array}$ http://www.smartcampaign.org/storage/documents/Standards_2.0_English_Final.pdf.

Coleman, B. E. (2006). Microfinance in Northeast Thailand: Who benefits and how much? World development, 34(9), 1612-1638. 
Copestake, J. (2007). Mainstreaming microfinance: Social performance management or mission drift?. World Development, 35(10), 1721-1738.

Cull, R., Demirgüç-Kunt, A. \& Morduch, J. (2009). Microfinance meets the market. In Moving Beyond Storytelling: Emerging Research in Microfinance (pp. 1-30). Emerald Group Publishing Limited.

Cull, R.,Demirgüc-Kunt, A \& Morduch, J. (2007). Financial performance and outreach: A global analysis of leading microbanks. The Economic Journal, 117(517).

de Noronha Vaz, T., Galindo, P. V., de Noronha Vaz, E., \& Nijkamp, P. (2015). Innovative firms behind the regions: Analysis of regional innovation performance in Portugal by external logistic biplots. European Urban and Regional Studies, 22(3), 329344.

De la Cuesta-González, M., Muñoz-Torres, M. J., \& Fernández-Izquierdo, M. A. (2006). Analysis of social performance in the Spanish financial industry through public data. A proposal. Journal of Business Ethics, 69(3), 289-304.

Dyllick, T., \& Hockerts, K. (2002). Beyond the business case for corporate sustainability. Business strategy and the environment, 11(2), 130-141.

Elkington, J. (1997). Cannibals with forks. The triple bottom line of 21 st century, 73.

Elsen, A. (1998). Sustainable development research at the University of Amsterdam. Amsterdam: United Nations Environment Programme, 64.

Ferrero-Ferrero, I., Fernández-Izquierdo, M. Á., \& Muñoz-Torres, M. J. (2015). Integrating sustainability into corporate governance: an empirical study on board diversity. Corporate Social Responsibility and Environmental Management, 22(4), 193207.

Ferro-Luzzi, Giovanni and Weber, Sylvain, Measuring the Performance of Microfinance Institutions (2006). http://dx.doi.org/10.2139/ssrn.918750.

Flint, R. W. (2013). Basics of sustainable development. In Practice of Sustainable Community Development (pp. 25-54). Springer New York.

Forcella, D., \& Hudon, M. (2016). Green microfinance in Europe. Journal of Business Ethics, 135(3), 445-459. DOI: 10.1007/s10551-014-2452-9.

Galema, R., Lensink, R., \& Mersland, R. (2012). Do powerful CEOs determine 
microfinance performance?. Journal of Management Studies, 49(4), 718-742.

Gallego-Álvarez, I., \& Vicente-Villardón, J. L. (2012). Analysis of environmental indicators in international companies by applying the logistic biplot. Ecological indicators, 23, 250-261.

Gallego-Álvarez, I., Galindo-Villardón, M. P., \& Rodríguez-Rosa, M. (2015). Analysis of the sustainable society index worldwide: A study from the biplot perspective. Social Indicators Research, 120(1), 29-65.

García Pérez, I., \& Muñoz Torres, M. J. (2015). Evaluación integral de las entidades microfinancieras desde la perspectiva de sostenibilidad. Harvard Deusto Business Research, 4(1), 17-33.

García-Pérez, I., Muñoz-Torres, M. J., \& Fernández-Izquierdo, M. Á. (2017). Microfinance literature: A sustainability level perspective survey. Journal of Cleaner Production, 142, 3382-3395.

Gertler, P., Levine, D. I., \& Moretti, E. (2009). Do microfinance programs help families insure consumption against illness?. Health economics, 18(3), 257-273.

Gladwin, T.N., Kennelly, J.J., Krause, T.-S. (1995). Shifting paradigms for sustainable development: implications for management theory and research. Acad. Manag. Rev. 20 (4), 874e907.

Glavič, P., \& Lukman, R. (2007). Review of sustainability terms and their definitions. Journal of cleaner production, 15(18), 1875-1885.

Global Reporting Initiative (GRI), G4 Sustainability Reporting Guidelines, https://www.globalreporting.org/resourcelibrary/GRIG4-Part1-Reporting-Principlesand-Standard-Disclosures.pdf.

Gutierrez-Nieto, B., Serrano-Cinca, C., \& Molinero, C. M. (2007). Microfinance institutions and efficiency. Omega, 35(2), 131-142.

Hartarska, V. (2005). Governance and performance of microfinance institutions in Central and Eastern Europe and the newly independent states. World development, 33(10), 1627-1643.

Hartarska, V., \& Nadolnyak, D. (2008). Does rating help microfinance institutions raise funds? Cross-country evidence. International Review of Economics \& Finance, 17(4), 558-571. 
Hartarska, V., \& Nadolnyak, D. (2011). What External Control Mechanisms Help Microfinance Institutions Meet the Needs of Marginal Clientele?. In The Handbook of Microfinance (pp. 267-281).

Haughton, G. (1999). Environmental justice and the sustainable cit. J. Plan. Educ. Res.8 (3), $233 \mathrm{e} 243$.

Hermes, N., \& Lensink, R. (2007). The empirics of microfinance: what do we know?. The Economic Journal, 117(517).

Holvoet, N. (2005). The impact of microfinance on decision-making agency: evidence from South India. Development and Change, 36(1), 75-102.

Hu, V. I., \& Scholtens, B. (2014). Corporate social responsibility policies of commercial banks in developing countries. Sustainable Development, 22(4), 276-288.

Hudon, M. (2009). Should access to credit be a right?. Journal of business ethics, 84(1), 17-28.

Jose, S. \& Chacko, J. (2017). Sustainable development of microfinance customers: An empirical investigation based on India. Journal of Enterprise Information Management, 30(1), 49-64.

Kleynjans, L., \& Hudon, M. (2016). A study of codes of ethics for Mexican microfinance institutions. Journal of Business Ethics, 134(3), 397-412. DOI 10.1007/s10551-014-2434-y

Kolk, A. (2008). Sustainability, accountability and corporate governance: Exploring multinationals' reporting practices. Bus. Strategy Environ. 17 (1), 1e15. http:// dx.doi.org/10.1002/bse.511.

Kruskal, W. H., \& Wallis, W. A. (1952). Use of ranks in one-criterion variance analysis. Journal of the American statistical Association, 47(260), 583-621.

Kunal. (2013). A waterfall model of microfinance: innovation and entrepreneurship for sustainable development. International Journal of Business and Globalisation, 10(4), $439-455$.

Lacalle-Calderón, M., Alfonso-Gil, J., \& Rico-Garrido, S. (2015). Foreign Aid and Microfinance: A new policy proposal for financing development. Iberoamerican Journal of Development Studies, 4(2), 106-129.

Lapenu, C., Konini, Z., \& Razakaharivelo, C. (2009). Social Performance 
Assessment: Meeting the Challenges of Responsible Finance. Revue Tiers Monde, (1), $37-54$.

Ledgerwood, J. (1999). Microfinance Handbook. The World Bank, Washington D.C

Ledgerwood, J., Earne, J., \& Nelson, C. (Eds.). (2013). The new microfinance handbook: A financial market system perspective. World Bank Publications.

Lopatta, K., Tchikov, M., Jaeschke, R., \& Lodhia, S. (2017). Sustainable Development and Microfinance: The Effect of Outreach and Profitability on Microfinance Institutions’ Development Mission. Sustainable Development.

Lozano, R. (2008). Envisioning sustainability three-dimensionally. Journal of cleaner production, 16(17), 1838-1846.

Lozano, R., \& Huisingh, D. (2011). Inter-linking issues and dimensions in sustainability reporting. Journal of Cleaner Production, 19(2), 99-107.

Maclean, K. (2010). Capitalizing on Women's Social Capital? Women-Targeted Microfinance in Bolivia. Development and Change, 41(3), 495-515.

Manta, O. (2016). The Role Of Microfinance In Sustainable Rural Development. Scientific Papers Series-Management, Economic Engineering in Agriculture and Rural Development, 16(2), 229-236.

Mersland, R. (2013). Market opportunities for microfinance institutions. Enterprise Development and Microfinance, 24(4), 282-294.

Mersland, R., \& Strøm, R. Ø. (2009). Performance and governance in microfinance institutions. Journal of Banking \& Finance, 33(4), 662-669.

Microfinance Information Exchange, Inc (MixMarket), https://www.themix.org/about.

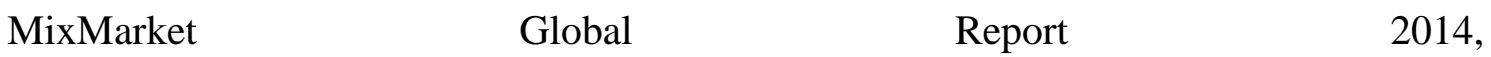
https://www.themix.org/sites/default/files/publications/mix_global_regional_benchmark _report_2014_0.pdf.

Moran, D.D., Wackernagela, M., Kitzesa, J.A., Goldfingera, S.H., Boutaud, A. (2008). Measuring sustainable development: nation by nation. Ecol. Econ. 64 (3), $470 \mathrm{e} 474$.

Morduch, J. (1999). The microfinance promise. Journal of economic literature, 
37(4), 1569-1614.

OECD (2015), G20/OECD Principles of Corporate Governance, OECD Publishing, Paris. http://dx.doi.org/10.1787/9789264236882-en.

Perez, F., Gonzalez, C. J., \& Aaronson, X. (2011). Village banking development model: FINCA Costa Rica. Journal of Business Research, 64(3), 316-324.

Perez, J. A. (2011). Conceptualizing a matrix to address sustainability and sustainable development in microfinance. Interdisciplinary Studies Journal, 1(2), 47.

Prior, F., \& Argandoña, A. (2009). Credit accessibility and corporate social responsibility in financial institutions: the case of microfinance. Business Ethics: A European Review, 18(4), 349-363.

Quayes, S. (2012). Depth of outreach and financial sustainability of microfinance institutions. Applied Economics, 44(26), 3421-3433.

Raha, D., Mahanta, P., \& Clarke, M. L. (2014). The implementation of decentralised biogas plants in Assam, NE India: The impact and effectiveness of the National Biogas and Manure Management Programme. Energy Policy, 68, 80-91.

Rahman, A. (1999). Micro-credit initiatives for equitable and sustainable development: Who pays?. World development, 27(1), 67-82.

Rai, A. (2015). Indian Microfinance Institutions: Performance of Young and Old Institutions. Vision, 19(3), 189-199.

Ramaswami, A., Zimmerman, J. B., \& Mihelcic, J. R. (2007). Integrating developed and developing world knowledge into global discussions and strategies for sustainability. 2. Economics and governance.

Ramaswamy, A., \& Krishnamoorthy, A. (2016). The Nexus Between Microfinance \& Sustainable Development: Examining The Regulatory Changes Needed For Its Efficient Implementation. European Journal of Sustainable Development, 5(3), 453.

Robinson, M. (2001). The Microfinance Revolution. The World Bank \& Open Society Institution, Washington D.C.

Rockström, J., Steffen, W., Noone, K., Persson, Å., Chapin, F. S., Lambin, E. F., ... \& Nykvist, B. (2009). A safe operating space for humanity. nature, 461(7263), 472-475.

Rosenberg, R. (2009). Measuring Results of Microfinance Institutions. Minimum Indicators That Donors and Investors Should Track. A Technical Guide. Washington, 
DC: Consultative Group to Assist the Poor/The World Bank.

Saint-Supéry Ceano-Vivas, M., Muñoz-Torres, M. J., \& Rivera Lirio, J. M. (2014). Revisiting the Relationship between Sustainable Development and Social Cohesion.

Sathye, M., Mukhopadhyay, B., \& Sathye, S. (2014). Sustainability and outreach in microfinance institutions in India: an ethical analysis. Canadian Journal of Development Studies/Revue canadienne d'études du développement, 35(3), 358-375.

Serrano-Cinca, C., Gutiérrez-Nieto, B., \& Molinero, C. M. (2011). Social and financial efficiency of microfinance institutions. The Handbook of Microfinance, 397.

Serrano-Cinca, C., Gutiérrez-Nieto, B., \& Reyes, N. M. (2016). A social and environmental approach to microfinance credit scoring. Journal of Cleaner Production, $112,3504-3513$.

Sinha, F. (2006). Social Rating and Social Performance Reporting in Microfinance. Towards a Common Framework, The SEEP Network for the Argidius Foundation.

Smart Campaign (SCCP), http://www.smartcampaign.org/.

Social Performance Task Force (SPTF) https://sptf.info/

Starik, M., Kanashiro, P. (2013). Toward a theory of sustainability management: uncovering and integrating the nearly obvious. Organ. Environ. XX (X), 1e24.

Steffen, W., Richardson, K., Rockström, J., Cornell, S. E., Fetzer, I., Bennett, E. M., \& Folke, C. (2015). Planetary boundaries: Guiding human development on a changing planet. Science, 347(6223), 1259855.

$\begin{array}{lll}\text { Sustainable Development Goals } & \text { (SDGs), }\end{array}$ http://www.un.org/sustainabledevelopment/sustainable-development-goals/.

Tashman, P., \& Marano, V. (2009). Dynamic capabilities and base of the pyramid business strategies. Journal of Business Ethics, 89(4), 495-514.

Tchakoute-Tchuigoua, H. (2010). Is there a difference in performance by the legal status of microfinance institutions?. The quarterly review of economics and finance, 50(4), 436-442.

Torres-Salinas, D., Robinson-García, N., Jiménez-Contreras, E., Herrera, F., \& López-Cózar, E. D. (2013). On the use of biplot analysis for multivariate bibliometric and scientific indicators. Journal of the Association for Information Science and Technology, 64(7), 1468-1479. 
United Nations Global Compact (UNGC), https://www.unglobalcompact.org/whatis-gc/mission/principles.

United Nations Human Rights (UNHR), Guiding Principles on Business and Human Rights. Implementing the United Nations "Protect, Respect and Remedy" Framework.

http://www.ohchr.org/Documents/Publications/GuidingPrinciplesBusinessHR_EN.pdf.

Universal Standards for Social Performance Management. Social performance Task Force (USSPM), https://sptf.info/

van Rooyen, C., Stewart, R., de Wet, T. (2012). The impact of microfinance in SubSaharan Africa: a systematic review of the evidence. World Dev. 40 (11), 2249e2262.

Vanroose, A., D'Espallier, B. (2013). Do microfinance institutions accomplish their mission? Evidence from the relationship between traditional financial sector development and microfinance institutions: outreach and performance. Appl. Econ. 45 (15), 1965e1982. http://dx.doi.org/10.1080/00036846.2011.641932.

Vicente Galindo, P., Vaz, E., \& de Noronha, T. (2015). How corporations deal with reporting sustainability: assessment using the multicriteria logistic biplot approach. Systems, 3(1), 6-26.

Vicente-Villardón, J. L., Galindo-Villardón, M. P., \& Blázquez-Zaballos, A. (2006). Logistic biplots. Multiple correspondence analysis and related methods. London: Chapman \& Hall, 503-521.

Ward Jr, J. H. (1963). Hierarchical grouping to optimize an objective function. Journal of the American statistical association, 58(301), 236-244.

Warnecke, T. (2014). The "Individualist Entrepreneur" vs. Socially Sustainable Development: Can Microfinance Build Community?. Journal of Economic Issues, 48(2), 377-386.

Warnecke, T. (2015). “Greening” Gender Equity: Microfinance and the Sustainable Development Agenda. Journal of Economic Issues, 49(2), 553-562.

Webster, J., \& Watson, R. T. (2002). Analyzing the past to prepare for the future: Writing a literature review. MIS quarterly, xiii-xxiii.

Wijesiri, M., \& Meoli, M. (2015). Productivity change of microfinance institutions in Kenya: A bootstrap Malmquist approach. Journal of Retailing and Consumer Services, 
$25,115-121$.

Yunus, M. (1999). Banker to the Poor, first ed. PublicAffairs, United States, ISBN 1- 891620-11-8.

Zhang, Y., Wildemuth, B.M. (2009). Qualitative analysis of content. In: Wildemuth, B. (Ed.), Applications of Social Research Methods to Questions in Information and Library Science. Libraries Unlimited, Westport, CT, pp. 308e319. 



\section{Conclusiones}

Esta tesis supone una contribución a la literatura académica acerca de las organizaciones microfinancieras basada en métodos que aportan validez, fiabilidad y confiabilidad para la evaluación del sector desde una perspectiva de sostenibilidad.

Según la literatura académica, el sector microfinanciero, hasta la fecha, se encuentra con una tendencia creciente y está considerado como uno de los mayores promotores de la inclusión financiera y cooperación. Además, en relación a la sostenibilidad, estudios previos la definen como un concepto complejo y multidimensional, que integra cuatro dimensiones interdependientes: financiera, ambiental, social y de gobernanza (FASG), considerando que debe existir un equilibrio adecuado entre ellas a corto y largo plazo.

Por lo tanto, inmersos en este contexto inclusivo, las instituciones microfinancieras (IMF) como actores clave en el sector de las microfinanzas, requieren un marco de gestión organizacional que facilite el desarrollo sostenible.

La presente tesis de compendio incluye tres artículos publicados en los que se analizan las organizaciones microfinancieras desde un enfoque de sostenibilidad, donde se contemplan las cuatro dimensiones FASG de manera integrada e inclusiva.

La estructura de este apartado, es la siguiente: en primer lugar se expondrá el resumen de las principales contribuciones de cada uno de los artículos incluidos en la tesis para a continuación indicar las principales limitaciones que presenta nuestra investigación y las futuras líneas de investigación que enriquecerían este campo de estudio.

\section{Contribuciones:}

Considerando que el sistema financiero afecta de manera directa e indirecta al desarrollo sostenible, y que las microfinanzas son reconocidas como un importante promotor en la expansión y fortalecimiento del sistema financiero formal, la presente tesis ha contribuido fundamentalmente a la profundización en el conocimiento de este sector desde un enfoque de sostenibilidad integrador. Para ello, este trabajo ha 


\section{Conclusiones}

propuesto como objetivos principales los siguientes:

- Investigar las contribuciones de la literatura sectorial de microfinanzas de acuerdo con los criterios de FASG y el GRI como marco de referencia.

- Contextualizar la producción científica sobre microfinanzas, para estudiar su terminología y proporcionar un análisis exhaustivo de dicha literatura, considerando las interrelaciones entre los aspectos financieros, ambientales, sociales y de gobernanza.

- Reflejar el comportamiento actual de las IMFs presentando una visión global en términos de desempeño sostenible.

- Determinar en qué medida integran las IMFs las finanzas, el medio ambiente, los criterios sociales y de gobernanza en su desempeño para fomentar el desarrollo sostenible.

- Proponer nuevas vías para futuros estudios para lograr la sostenibilidad, promoviendo un enfoque integrador de la investigación.

El primer trabajo, mediante una revisión sistemática de la literatura académica, ha revelado los principales conceptos con los que se relaciona las microfinanzas. El microcrédito, las IMFs y la evaluación su impacto, así como, su efecto en relación al alivio de la pobreza, el desarrollo y la inclusión financiera son los principales objetivos de las investigaciones analizadas. En relación a las dimensiones consideradas, ha mostrado que existe una clara asimetría entre las diferentes áreas. Las dimensiones económica, social y la combinación de ambas, son el tema principal de análisis en el $80 \%$ de las publicaciones revisadas, mientras que los estudios sobre la incidencia del sector microfinanciero en medioambiente y gobernanza, y su relación con el resto de dimensiones son escasos. Se dispone de poca información acerca de las implicaciones de las microfinanzas en la sociedad desde el punto de vista ambiental y de gobernanza.

En el segundo artículo se ha evaluado el desempeño de las IMFs a nivel global 


\section{Conclusiones}

bajo el prisma de la sostenibilidad. Considerando la vocación con la que emergen las microfinanzas y su clara orientación hacia la sociedad, en general sus actuaciones se rigen, en mayor o menor medida, bajo ciertos criterios de responsabilidad social. Sin embargo, existen aspectos de mejora que podrían favorecer la actividad de estas instituciones en su cometido original de paliar la exclusión financiera y aliviar la pobreza.

En términos generales, desde el punto de vista financiero, se ha observado que el estatus legal de las instituciones no afecta a su rentabilidad y que, en relación a la sostenibilidad financiera, como indicador ajustado, más de la de mitad de las IMFs analizadas podrían mantener su oferta de servicios financieros generando los ingresos netos necesarios para cubrir sus costes. Desde la perspectiva social, estas instituciones presentan un grado de compromiso alto con clientes, comunidad, empleados, así como unas buenas prácticas de gobierno corporativo. Sin embargo, en relación al medioambiente, la tasa de respuesta afirmativa cuando se trata de la acción indirecta de las microfinanzas es escasa. Es decir, la información acerca de la financiación de determinadas actividades y sus posibles efectos colaterales sobre el medioambiente, es insuficiente.

La clasificación de IMFs bajo criterios FASG presentada en el tercer estudio está basada en información reportada de manera voluntaria por parte de las organizaciones. Este trabajo, complementa estudios previos, proporcionando una aproximación holística en un sector caracterizado fundamentalmente por un enfoque dual, donde las vertientes económica y social han sido las principales protagonistas. De acuerdo con estudios anteriores, se observa que, en relación a la dimensión social, los indicadores con mayor presencia corresponden a objetivos de las IMFs relacionadas con el desarrollo, la protección de los clientes frente al sobreendeudamiento, y al efecto de las microfinanzas desde la perspectiva de género, igualdad y empoderamiento de las mujeres.

Sin embargo, cuando se trata de las dimensiones ambiental y gobernanza, el número de indicadores es escaso y las tasas de respuesta bajas. Esto hace que los 


\section{Conclusiones}

efectos indirectos de la actividad microfinancera, y el rol de los mecanismos de gobierno de estas instituciones estén poco documentados.

La tesis, Sostenibilidad en las organizaciones microfinancieras, promueve la investigación de la gestión de la sostenibilidad en el sector de las microfinanzas de una manera holística. Esta gestión se plantea dentro de un marco teórico inclusivo que incorpora las dimensiones financiera, ambiental, social y de gobernanza con enfoque integrador y equilibrado para la evaluación de las IMFs a nivel global.

\section{Limitaciones y futuras líneas de investigación:}

En los últimos años, las investigaciones relacionadas con la sostenibilidad y aquellas relativas a las microfinanzas, han crecido significativamente. Por esta razón y con la intención de alcanzar una mayor comprensión del sector, en esta tesis se han analizado en profundidad las entidades microfinancieras considerando como requisito indispensable un marco de gestión organizacional que facilite el desarrollo sostenible.

Una de las limitaciones cuando se trata de analizar en profundidad la gestión de las IMFs es la escasez de información pública disponible. Existe una dificultad importante a la hora de seleccionar bases de datos fiables y de calidad. Por un lado, el hecho de que la información suministrada sea voluntaria conlleva un sesgo implícito. En el caso de la base de datos ofrecida por MixMarket, este sesgo se puede minimizar seleccionando aquellas instituciones que sean valoradas con un nivel de transparencia y confianza superior a la media.

Este criterio de selección deriva en una segunda limitación, que es la exclusión de un gran número de instituciones de regiones como África y Sur de Asia. La importancia de esta limitación deriva en que, en estas regiones, la actividad microfinanciera está muy extendida mientras que la información de calidad disponible es prácticamente inexistente. 


\section{Conclusiones}

Así mismo, las bases de datos acerca de IMFs con información no financiera, presentan en sus indicadores dos situaciones que requieren atención: una es el número indicadores en cada dimensión y la otra es el poder discriminatorio de los indicadores disponibles. El número de indicadores de carácter social es muy alto y, sin embargo, su poder discriminatorio bajo. En el caso de los indicadores relativos a medioambiente y gobernanza es el opuesto. En número y en tasa de respuesta son muy escasos pero su poder discriminatorio es alto, lo que genera un desequilibrio en el estudio de las diferentes áreas.

La investigación científica puede y debe liderar el desafiante proceso de implementación de un marco analítico de sostenibilidad. Esta tesis nos proporciona una mayor comprensión de un sector heterogéneo tanto por el estatus legal de las organizaciones que lo componen, los distintos programas que llevan a cabo, el público objetivo al que se dirigen o los países donde operan.

No obstante, para futuras investigaciones sería recomendable una mayor transparencia y una mejora de la calidad de la información suministrada, especialmente en regiones de gran actividad como África y Sur de Asia.

Así mismo, sería necesario una redefinición de los indicadores de carácter social que permita reducir el número de datos recolectados y analizados y a su vez aumentar su facultad para explicar las correlaciones entre variables. En el caso de indicadores relativos a medioambiente y gobernanza, sería conveniente aumentar el número de indicadores ya que tienen un mayor poder discriminatorio y equilibrarían la representación de las dimensiones FESG.

También sería oportuno incluir indicadores cualitativos y cuantitativos de procedimientos, protocolos o recursos involucrados que permitan una mejor comprensión del desempeño de las diferentes prácticas.

Esta tesis proporciona una mayor comprensión a nivel sectorial y ofrece interesantes aportaciones relacionadas con la promoción de la investigación desde un enfoque integral como base fundamental para afrontar el desafiante proceso de 


\section{Conclusiones}

implementación de un marco analítico de sostenibilidad. Así mismo, en aras a promover el desarrollo de la sostenibilidad gestión en el sector de las microfinanzas, demanda una mayor transparencia que podría ser beneficiosa para todas las partes interesadas, propiciaría acuerdos y sinergias entre agentes económicos, donantes, legisladores y académicos. 


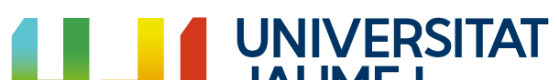 \\ JAUME I}

Escola de Doctorat · ED

María Jesús Muñoz Torres, como coautora doy mi autorización

a Icíar García Pérez para la presentación de las siguientes publicaciones como parte de su tesis doctoral.

Relación de publicaciones:

García-Pérez, I., \& Muñoz-Torres, M. (2015). Evaluación integral de las entidades microfinancieras desde la perspectiva de sostenibilidad. Harvard Deusto Business Research, 4(1), 17-33

García-Pérez, I., Muñoz-Torres, M. J., \& Fernández-Izquierdo, M. Á. (2017). Microfinance literature: A sustainability level perspective survey. Journal of Cleaner Production, 142, 33823395

García-Pérez, I., Muñoz-Torres, M. J., \& Fernández-Izquierdo, M. Á. (2018). Microfinance institutions fostering sustainable development. Sustainable Development.

Asimismo, renuncio a poder utilizar estas publicaciones como parte de otra tesis doctoral.

Y para que conste firmo el presente documento,

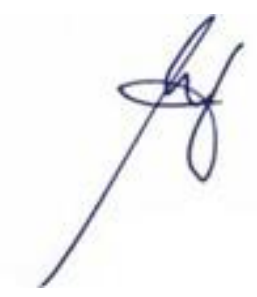

Castellón, 4 de junio 2018

Todo ello, atendiendo al artículo 23 de la Normativa de los Estudios de Doctorado, regulados por el RD 99/2011, en la Universitat Jaume I (Aprobada por el Consejo de Gobierno núm. 19 de 26 de Enero de 2012, modificada por el Consejo de Gobierno núm. 29 de 27 de Noviembre de 2012 y con posterior modificación por el Consejo de Gobierno núm. 37 de 25 de Julio de 2013):

$$
\text { "(...) }
$$

"Aquellas tesis doctorales que opten por la incorporación de artículos (compendio de publicaciones) deben de ajustarse, en la medida de lo posible, a la siguiente estructura: -Introducción/objetivos - Un capítulo por artículo incorporado - Discusión general de los resultados - Conclusiones. -Aceptación de los coautores de que el doctorando presente el trabajo como tesis y renuncia expresa de estos a presentarlo como parte de otra tesis doctoral." 



\section{INUNESTSTIT \\ JAUME I}

Escola de Doctorat · ED

María Ángeles Fernández Izquierdo, como coautora doy mi autorización

a Icíar García Pérez para la presentación de las siguientes publicaciones como parte de su tesis doctoral.

Relación de publicaciones:

García-Pérez, I., Muñoz-Torres, M. J., \& Fernández-Izquierdo, M. Á. (2017). Microfinance literature: A sustainability level perspective survey. Journal of Cleaner Production, 142, 33823395

García-Pérez, I., Muñoz-Torres, M. J., \& Fernández-Izquierdo, M. Á. (2018). Microfinance institutions fostering sustainable development. Sustainable Development.

Asimismo, renuncio a poder utilizar estas publicaciones como parte de otra tesis doctoral.

Y para que conste firmo el presente documento,

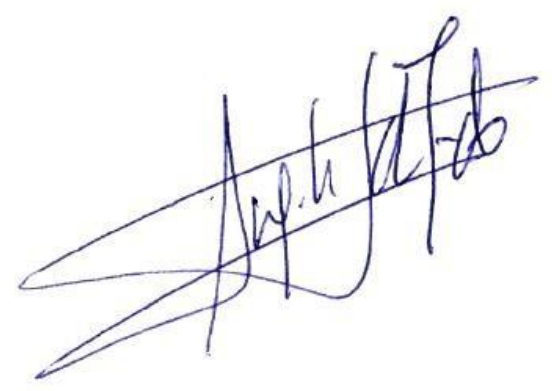

Castellón, 4 de junio 2018

Todo ello, atendiendo al artículo 23 de la Normativa de los Estudios de Doctorado, regulados por el RD 99/2011, en la Universitat Jaume I (Aprobada por el Consejo de Gobierno núm. 19 de 26 de Enero de 2012, modificada por el Consejo de Gobierno núm. 29 de 27 de Noviembre de 2012 y con posterior modificación por el Consejo de Gobierno núm. 37 de 25 de Julio de 2013):

$$
\text { “(...) }
$$

“Aquellas tesis doctorales que opten por la incorporación de artículos (compendio de publicaciones) deben de ajustarse, en la medida de lo posible, a la siguiente estructura: -Introducción/objetivos - Un capítulo por artículo incorporado - Discusión general de los resultados - Conclusiones. -Aceptación de los coautores de que el doctorando presente el trabajo como tesis y renuncia expresa de estos a presentarlo como parte de otra tesis doctoral." 



\section{UII UNIVERSTIAT \\ JAUMEI}

Escola de Doctorat · ED

\section{DECLARACIÓN DE CUMPLIMIENTO DE LOS PRINCIPIOS ÉTICOS Y DE RESPONSABILIDAD EN LA ELABORACIÓN DE LA TESIS DOCTORAL}

Nombre y Apellidos: Icíar García Pérez

DNI / NIE / Pasaporte: 52987921 S

Autor / a de la tesis doctoral titulada "Sostenibilidad en las Instituciones Microfinancieras."

DECLARA que en su elaboración y en los datos e información que contiene la presente tesis doctoral se han cumplido los principios éticos (punto 2.2) y de responsabilidad (punto 2.3) establecidos en el Código de Buenas prácticas de la Escuela de Doctorado de la Universitat Jaume I:

2.2. Principios éticos. ( ) "evitará toda actuación que pueda producir discriminación por razón de nacimiento, origen étnico, orientación sexual, religión, opinión, discapacidad, edad o cualquier otra condición o circunstancia personal o social. De manera particular, implica el reconocimiento de que no se deben promover, ni en el campo de las ciencias naturales ni el de las ciencias sociales y humanidades, investigaciones que atentan contra los derechos fundamentales de las personas, el bienestar de los animales y del medio ambiente. "

2.3. Responsabilidad. ( ) "Hay que evitar cualquier tipo de manipulación de datos, de plagio y autoplagio y deben respetarse los principios de la propiedad intelectual o de la propiedad conjunta de los datos cuando la investigación se realice en colaboración con supervisores y / u otros investigadores. "

Castellón de la Plana, 4 de Junio de 2018
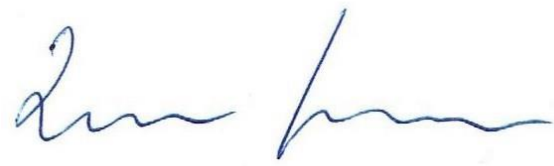

Visto bueno de las directoras de tesis

María Jesús Muñoz Torres

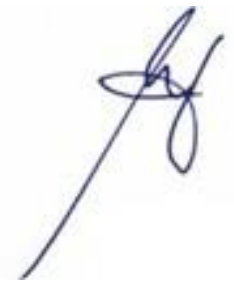

María Ángeles Fernández Izquierdo

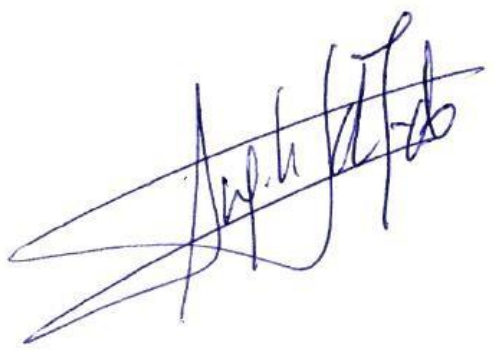


